\title{
Typha (Cattail) Invasion in North American Wetlands: Biology, Regional Problems, Impacts, Ecosystem Services, and Management
}

\author{
Sheel Bansal ${ }^{1}$ (D) Shane C. Lishawa ${ }^{2} \cdot$ Sue Newman $^{3} \cdot$ Brian A. Tangen $^{1} \cdot$ Douglas Wilcox $^{4} \cdot$ Dennis Albert $^{5}$. \\ Michael J. Anteau ${ }^{1}$ - Michael J. Chimney ${ }^{3}$. Ryann L. Cressey ${ }^{6,7}$ • Edward DeKeyser ${ }^{8} \cdot$ Kenneth J. Elgersma $^{9}$. \\ Sarah A. Finkelstein ${ }^{10}$. Joanna Freeland ${ }^{11}$ - Richard Grosshans ${ }^{12}$ • Page E. Klug ${ }^{13}$ • Daniel J. Larkin ${ }^{14}$. \\ Beth A. Lawrence ${ }^{15}$. George Linz ${ }^{13}$. Joy Marburger ${ }^{16} \cdot$ Gregory Noe $^{17}$. Clint Otto ${ }^{1}$. Nicholas Reo ${ }^{18}$. \\ Jennifer Richards ${ }^{19}$. Curtis Richardson ${ }^{20}$ - LeRoy Rodgers ${ }^{3}$. Amy J. Schrank ${ }^{21}$ • Dan Svedarsky ${ }^{22}$. Steven Travis ${ }^{23}$. \\ Nancy Tuchman ${ }^{2} \cdot$ Lisamarie Windham-Myers ${ }^{24}$
}

Received: 28 January 2019 / Accepted: 14 May 2019 / Published online: 21 June 2019

(C) The Author(s) 2019

\begin{abstract}
Typha is an iconic wetland plant found worldwide. Hybridization and anthropogenic disturbances have resulted in large increases in Typha abundance in wetland ecosystems throughout North America at a cost to native floral and faunal biodiversity. As demonstrated by three regional case studies, Typha is capable of rapidly colonizing habitats and forming monodominant vegetation stands due to traits such as robust size, rapid growth rate, and rhizomatic expansion. Increased nutrient inputs into wetlands and altered hydrologic regimes are among the principal anthropogenic drivers of Typha invasion. Typha is associated with a wide range of negative ecological impacts to wetland and agricultural systems, but also is linked with a variety of ecosystem services such as bioremediation and provisioning of biomass, as well as an assortment of traditional cultural uses. Numerous physical, chemical, and hydrologic control methods are used to manage invasive Typha, but results are inconsistent and multiple methods and repeated treatments often are required. While this review focuses on invasive Typha in North America, the literature cited comes from research on Typha and other invasive species from around the world. As such, many of the underlying concepts in this review are relevant to invasive species in other wetland ecosystems worldwide.
\end{abstract}

Keywords Everglades · Hybrid vigor · Hydrology · Invasive species · Laurentian Great Lakes · Nutrient enrichment · Prairie pothole region $\cdot$ Typha angustifolia $\cdot$ Typha domingensis $\cdot$ Typha $\times$ glauca $\cdot$ Typha latifolia

\section{Introduction}

Typha (commonly referred to as 'cattail') is the only genus in the family Typhaceae. This iconic genus, comprised of nearly 40 species and hybrids, is ubiquitous across wetland ecosystems throughout the world. An abundance of wind-dispersed seeds allows Typha to colonize wetlands across great distances, and its rapid growth rate, large stature, and aggressive clonal propagation can result in dense monotypic stands. These stands have considerable impact on local fauna and

Sheel Bansal

sbansal@usgs.gov

Extended author information available on the last page of the article flora, biogeochemical cycling, and wetland hydrology, which correspondingly impact wetland functions. Over recent decades, the distribution and abundance of Typha in wetland ecosystems around the world, particularly in North America, has increased due to anthropogenic-related disturbances to wetland hydrology and nutrient loads. In addition, vigorous non-native and hybrid taxa have exacerbated the rapid spread of Typha. The invasion and expansion of Typha in wetland ecosystems have required widespread management, albeit control is often short-lived or ineffective. Despite the negative impacts of Typha on natural systems, this plant can provide beneficial ecosystem services under certain conditions, including bioremediation in constructed wetlands to reduce nutrient loads and pollution, and providing biofuel feedstocks needed to help offset global carbon dioxide $\left(\mathrm{CO}_{2}\right)$ emissions. In this paper, we conduct a robust, systematic review and 
synthesis of Typha across a number of topics, taxa, and regions to address the many issues surrounding Typha in North America; many of the underlying concepts in this review are also relevant to invasive species in other wetland ecosystems worldwide.

The designation of Typha as 'invasive' is subjectively applied and not clear-cut. North America has three dominant species of Typha: T. latifolia L. (broadleaf cattail), T. angustifolia L. (narrowleaf cattail), and T. domingensis Persoon (southern cattail), as well as a hybrid taxon $T . \times$ glauca Godr. (cross of T. latifolia and T. angustifolia) (Smith 2000). Typha latifolia and T. domingensis are native to North America, T. angustifolia is likely not native with European origins, and $T$. $\times$ glauca is a hybrid. The term 'invasive' is usually associated with non-native species but can also be applied to native species that increase in abundance in response to environmental change and dominate wetlands by displacing other species. For example, nutrient enrichment from agricultural runoff led to a considerable increase in native $T$. domingensis abundance in the southern US, and changes in hydrologic regimes facilitated the proliferation of nonnative T. angustifolia and hybrid T. $\times$ glauca in the northern US/southern Canada. Thus, the term 'invasive' is contextdependent and can be associated with native, non-native, and hybrid taxa of Typha.

\section{Section 1: Biology and Ecology of Typha}

\section{Distribution}

Typha is found worldwide on every continent except Antarctica (Smith 1987) (Fig. 1). Typha is an ancient genus with its origins dating back at least to the mid-Eocene (39 Mya) in eastern Eurasia (Zhou et al. 2018). From there, Typha diversified and dispersed around the world, including to North America via the North Atlantic Land Bridge and Beringian Land Bridge migration routes. Of the four dominant taxa found in North America, T. latifolia is the widest ranging, extending throughout virtually the entire continent. This species is found in the broadest climatic conditions of all Typha, persisting as far north as boreal-arctic transition zones in Northwest and Yukon Territories and Alaska, where mean winter temperatures reach $-20{ }^{\circ} \mathrm{C}$, and as far south as the subtropical zone of the southern US, where average summer temperatures exceed $27^{\circ} \mathrm{C}$ (Smith 1967; Grace and Harrison 1986; Smith 2000). Typha angustifolia is not as tolerant of harsh winter temperatures as T. latifolia, and historically had a narrower distribution; it was confined to the eastern seaboard based on pollen and herbarium records (Shih and Finkelstein 2008), but currently ranges across the Great Lakes region to the Mississippi River, southern Manitoba, and has been recorded in scattered populations in the western US and in the boreal transition zone of northern Ontario, Canada (Smith 2000; Shih and Finkelstein 2008). While T. angustifolia is possibly native to the tidal wetlands of the eastern seaboard (Shih and Finkelstein 2008), pollen studies have shown that with land use changes such as increased sediment and nutrient influxes to estuarine habitats, there can be substantial increases in local abundances of all Typha species (Hilgartner and Brush 2006). Typha angustifolia is largely absent from the southern US, but whether this is due to physiological limitation or ecological competition is not known. Due to difficulties in visual identification of $T$. $\times$ glauca, its range is uncertain; it is likely found where its parental species T. latifolia and T. angustifolia co-occur (Travis et al. 2010; Freeland et al. 2013). Typha domingensis is a warm temperate and pantropical species found in the southern US, primarily Florida and other Gulf states, including Alabama, Louisiana, Mississippi, and Texas. However, scattered populations of T. domingensis have been observed as far north as Delaware (Smith 2000). There are few studies on climatic controls of Typha life history traits and their roles in setting range limits. In one example, Ekstam and Forseby (1999) documented temperature requirements for germination, with optimal germination rates occurring around $20^{\circ} \mathrm{C}$ for $T$. latifolia, although germination can occur across a wide range of temperatures and diurnal amplitudes. By contrast, when grown on its typical peat substrate, T. domingensis, had its highest germination percentage and shortest germination period at higher temperatures (83-85\% and $1.1-2.5$ days at $30{ }^{\circ} \mathrm{C}$ ) compared to lower temperatures $\left(0-5 \%\right.$ and $8.1-19.4$ days at $\left.15^{\circ} \mathrm{C}\right)$ (Lorenzen et al. 2000). Thus, while limited, there is some support for the role of climate in controlling species distributions.

Typha latifolia, T. angustifolia, and T. $\times$ glauca can generally be identified to species in pollen records (Finkelstein 2003); therefore, dated sediment cores in which pollen is preserved are a means to track invasion history over time. Plant collections housed in herbaria are another method of tracking temporal changes in distributions. An analysis of $>1100$ herbarium records and of available pollen records archived publicly in the North American Pollen Database confirmed that T. latifolia, T. angustifolia, and T. $\times$ glauca have all been increasing in abundance since the onset of the settlement period in North America (Shih and Finkelstein 2008). Prior to 1930, T. angustifolia, in particular, spread from a restricted range along the east coast of the US westward into the Great Lakes region and the St. Lawrence Seaway; this spread likely occurred in response to anthropogenic land-use change, increased runoff and sedimentation, and enhanced propagule pressure as European settlers converted land to agricultural uses, as well as through the commercial nursery trade (Galatowitsch et al. 1999; Shih and Finkelstein 2008; Rippke et al. 2010; Sritrairat et al. 2012; Ciotir et al. 2013; Ciotir and Freeland 2016; Ciotir et al. 2017; Boxem et al. 2018). Concurrently, the hybrid T. $\times$ glauca appeared in 


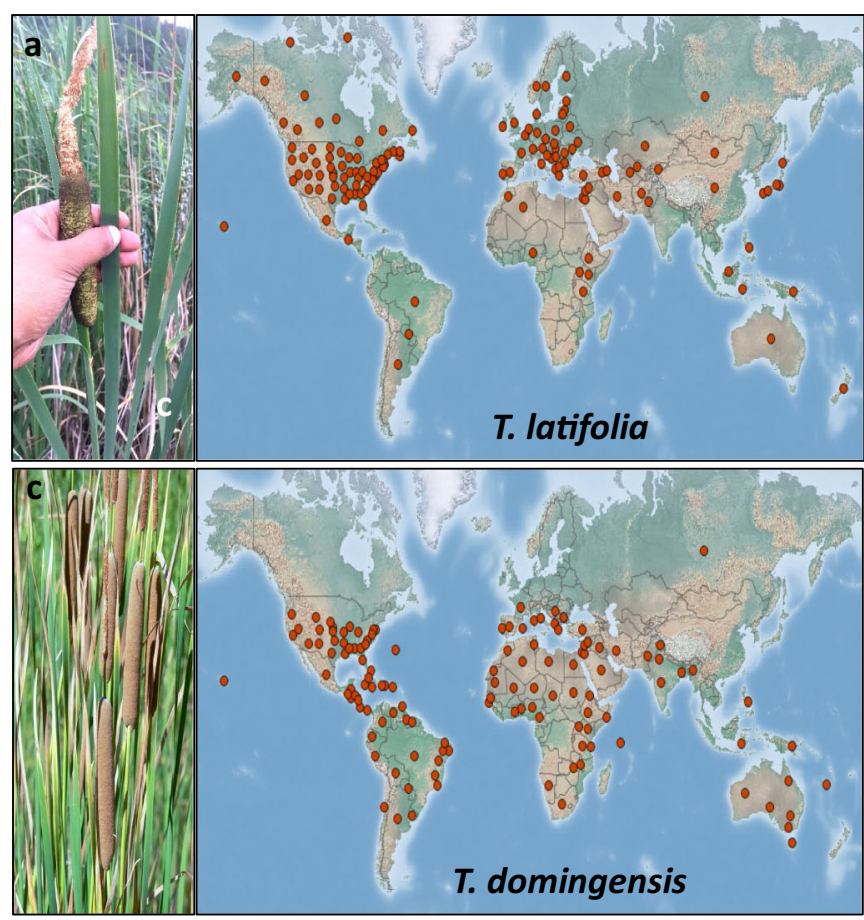

Fig. 1 Example photos of dominant Typha taxa in North America and locations (red dots) where a T. latifolia, $\mathbf{b}$ T. angustifolia, $\mathbf{c}$ T. domingensis and $\mathbf{d} T$. $\times$ glauca have been identified. Photos show differences in leaf

herbarium and pollen records in areas where the ranges of T. latifolia and T. angustifolia began to overlap (Shih and Finkelstein 2008). Aerial photo analyses have been used to verify independently the accuracy of sediment core pollen records for tracking the time series of Typha invasion; Lishawa et al. (2013) combined these approaches to produce high-resolution reconstructions of invasion dynamics for T. angustifolia and T. $\times$ glauca in Great Lakes coastal wetlands. Assessing invasion dynamics of $T$. domingensis is difficult because it is often confused with other species, particularly T. angustifolia (CABI 2018d; Wunderlin et al. 2018).

\section{Life History and Adaptive Morphological Traits}

\section{Rapid Growth and Morphology}

Typha dominance in wetlands is largely attributable to its large stature at maturity combined with rapid clonal expansion (Lishawa et al. 2010; Travis et al. 2011; Larkin et al. 2012a, b) (Fig. 2a). Width of the long, linear leaves varies among species; Typha latifolia has the widest leaves and T. angustifolia has the narrowest, while $T . \times$ glauca and T. domingensis have intermediate-width leaves (Grace and Wetzel 1981; Snow et al. 2010; Kirk et al. 2011) (Fig. 1). Typha growth rates are relatively high compared to other species, with a maximum of $30-40 \mathrm{~g} \mathrm{~m}^{-2} \mathrm{day}^{-1}$, for an annual total of 10-30 tons ha ${ }^{-1} \mathrm{yr}^{-1}$ (Andrews and Pratt 1978; Dubbe et al. 1988; Miller and Fujii 2010; Grosshans 2014). Rapid

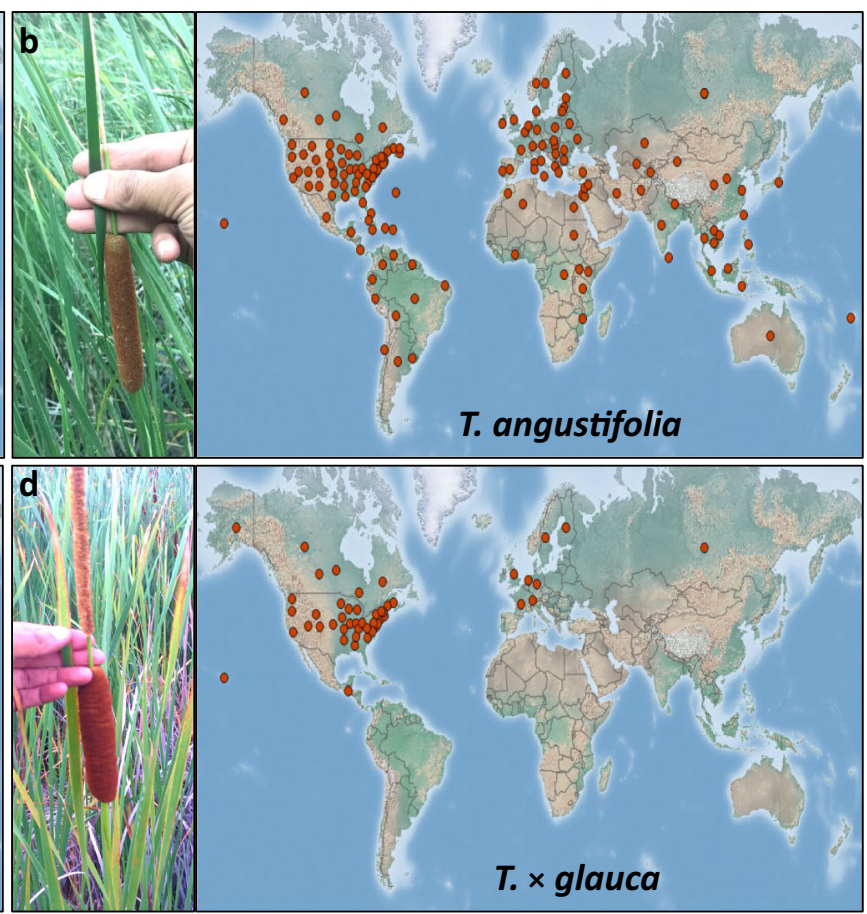

widths and gap lengths between male (upper yellow) and female (lower brown) regions of the inflorescence among the taxa. Distribution maps modified from (CABI 2018a, b, c, d)

growth in spring is fueled by stored carbohydrates (see rhizomes, Fig. 2c). Typha tends to be more responsive to environmental change than competitors, making it more adaptable to disturbed environments (Newman et al. 1996; Li et al. 2010; Webb and Zhang 2013). Typha also displays rapid nutrient uptake in nutrient-rich environments (Newman et al. 1996; Miao and Sklar 1998; Cicek et al. 2006).

\section{Air-Ventilation System}

The ability to supply belowground rhizomes and roots with oxygen $\left(\mathrm{O}_{2}\right)$ through a system of aerenchyma or intercellular air spaces is a key adaptation of wetland plants (Armstrong 1979; Armstrong et al. 1992) (Fig. 2b). Typha uses a pressurized gas flow system, in which $\mathrm{O}_{2}$ enters through stomata on younger leaves into a high-humidity intercellular atmosphere, then convects along a humidity gradient from leaves to rhizomes and roots and eventually out through older, dead or damaged leaves to the much drier, ambient atmosphere (Chanton et al. 1993; Bendix et al. 1994; Tornberg et al. 1994; Sorrell et al. 2000) (Fig. 2b). Gas flow may be enhanced by pressure developed from wind blowing across dead and broken stems, which have been shown to aerate rhizomes (Jordan and Whigham 1988; Armstrong et al. 1992). The high efficiency of the Typha root-aeration system helps give it a competitive advantage over other species, especially in organic-rich, flooded soils (McKee et al. 1989). For example, in the Everglades, $T$. domingensis was shown to have greater $\mathrm{O}_{2}$ 
Fig. 2 Typha has a number of adaptive traits that allow it to grow and thrive in wetland environments: a dense stands of Typha inhibit growth of competing vegetation; image is a hemispherical photo from the point of view of an emerging seedling in a Typha stand, b a Typha leaf cross-section shows aerenchyma that allows Typha to transport oxygen to roots efficiently, and $\mathbf{c}$ rhizomes and roots of Typha; rhizomes allow Typha to propagate clonally and store carbohydrates for regrowth in spring

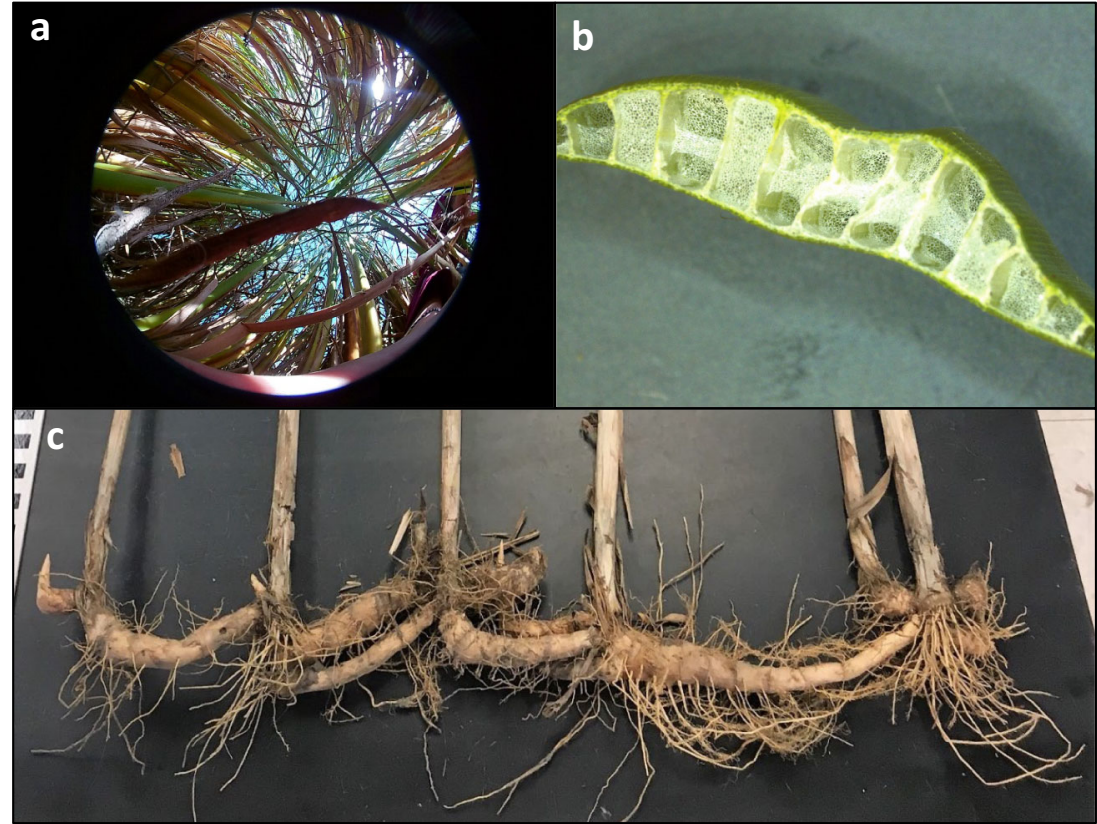

supply to roots than other native competitors like Cladium jamaicense (saw-grass) (Chabbi et al. 2000; Sorrell et al. 2000), allowing T. domingensis to maintain rapid nutrient uptake and relatively high photosynthetic rates in flooded soil (Koch et al. 1990; Pezeshki et al. 1996). The $\mathrm{O}_{2}$-transport mechanisms of Typha can also have secondary effects on methane $\left(\mathrm{CH}_{4}\right)$ emissions from wetlands (see Carbon and greenhouse gas) (Chanton et al. 1993; Chanton and Whiting 1996; Rose and Crumpton 1996; Faußer et al. 2012).

\section{Sexual Reproduction through Seeds}

Typha plants are monoecious, with both male and female flowers in an inflorescence (flower cluster); inflorescences develop as spikes at the tips of erect stems. Each inflorescence spike is two-tiered, with yellow, male, staminate flowers on the narrow top and brown, female, pistillate flowers on the broader portion below (Smith 2000) (Fig. 1). The gap between male and female inflorescence regions can generally be used to distinguish species, although distinguishing $T$. $\times$ glauca is less reliable based on morphology. Typha latifolia male and female inflorescences touch, whereas there is usually a gap between inflorescences for T. angustifolia (5-120 mm), T. $\times$ glauca (0-33 mm), and T. domingensis (0-8 mm) (Finlayson et al. 1985; Grace and Harrison 1986). Male flowers release up to 420-million pollen grains per inflorescence in spring, while female flowers release the single-seeded fruits in late summer (Mitich 2000). The small $(<100 \mu \mathrm{g})$, winddispersed fruits can number 20,000-700,000 per inflorescence and travel more than $1 \mathrm{~km}$ to colonize distant wetlands (Yeo 1964; Stewart et al. 1997; Mitich 2000; Baldwin and Cannon 2007). Elongated hairs on the stalk supporting the fruit aid in wind dispersal; if the fruits land in water, the hairs close, the fruit wall splits, and the single seed is released and sinks (Grace and Harrison 1986; Smith 2000). Seeds can germinate rapidly (within 2-20 days), but ungerminated seeds can remain viable in the soil and form a persistent seed bank (Leck and Simpson 1987; Stewart et al. 1997; Lorenzen et al. 2000).

Typha seeds have a number of environmental requirements for successful germination: moisture, temperature, light, and $\mathrm{O}_{2}$ all influence germination (Sifton 1959; Bedish 1964; Bonnewell et al. 1983; Welling et al. 1988; Ekstam and Forseby 1999; Ahee et al. 2015). Under field conditions, most germination occurs on exposed, saturated soils (Weller 1975; Beule 1979; Lorenzen et al. 2000), although seeds can germinate under water (Bedish 1964). Light is required for germination (Grace and Harrison 1986; Lorenzen et al. 2000), which limits germination in clear water deeper than $40 \mathrm{~cm}$ (Sifton 1959; Beule 1979) or in sediment deeper than $1 \mathrm{~cm}$ (Galinato and van der Valk 1986). Cold stratification is not an obligate requirement for $T$. $\times$ glauca (Galinato and van der Valk 1986), whereas other species (T. latifolia, T. domingensis) show greatest germination at higher temperatures $\left(>30^{\circ} \mathrm{C}\right)$ (Bonnewell et al. 1983; Lorenzen et al. 2000).

When the seeds germinate and seedlings begin to grow, they may be submerged in shallow $(2.5 \mathrm{~cm})$ water or on saturated soil (Bedish 1964; Beule 1979). They produce a series of small juvenile leaves then begin to produce the erect leaves typical of adult plants (Mitich 2000, for T. latifolia). Because the seeds are small compared to those of many co-occurring species (Leck and Simpson 1993), seedlings do not have abundant seed resources to draw on and must establish and grow quickly. Flooding soon after germination caused mortality in Typha seedlings, but after a month, seedlings could grow 
in water up to $40 \mathrm{~cm}$ deep (Beule 1979). Seedling success depends on appropriate light, temperature, and hydrology but also on water and substrate chemistry, including nutrient and auto-inhibitor (allelochemicals produced by Typha species) levels (McNaughton 1968; Grace and Harrison 1986; Gallardo et al. 1998; Smith and Newman 2001; Jarchow and Cook 2009). Seedling establishment appears to be rare, relying on gaps or other disturbances that create appropriate light environments (Leck and Simpson 1993).

\section{Asexual Reproduction through Rhizomes}

After seedling establishment, Typha develops axillary rhizomes with roots that anchor plants into wetland sediments (Fig. 2c). Rhizome tips turn erect to produce upright ramets (i.e., culms) with elongated linear leaves that form dense, nearly monospecific stands in wetlands; these stands can cover an area of 40-80 $\mathrm{m}^{2}$ within months to years (Yeo 1964; Grace and Harrison 1986). Field sampling in the Great Lakes region demonstrated that rhizomes can grow horizontally at least $76 \mathrm{~cm}$ in a summer in $60-75 \mathrm{~cm}$ deep water (D. Albert personal observations November 2018). Rhizomes also store energy-rich carbohydrates and nutrient reserves during the winter; these reserves are mobilized in spring to support rapid growth of new shoots (i.e., ramets) (Kausch et al. 1981; Hogg and Wein 1987; Garver et al. 1988; Steinbachová-Vojtíšková et al. 2006; Asaeda et al. 2008; Tursun et al. 2011). Typha can also survive as floating mats that can then colonize newly disturbed sites.

\section{Habitat}

\section{Hydrology}

According to the National Wetland Plants List of the US, species of Typha are considered obligate wetland plants, meaning they cannot survive in non-wetland habitats (Lichvar et al. 2016). As such, Typha is found in a wide variety of wetland habitats including marshes, shores, streambanks, ditches, and margins of lakes and ponds, and tidal wetlands showing a tolerance for a range of water levels (Harris and Marshall 1963; Stewart and Kantrud 1972; Newman et al. 1998; Safratowich et al. 2008).

Typha invasions into natural wetlands are often associated with hydrologic alterations. Typha is flood-tolerant and generally favored by moderate flooding (Harris and Marshall 1963; Bedish 1967; Grace and Wetzel 1982a; Grace and Harrison 1986; van der Valk 1994; Kercher and Zedler 2004; Li et al. 2004; Boers et al. 2007; Asamoah and Bork 2010). Periodic high water levels and prolonged flooding to depths $>1 \mathrm{~m}$ may reduce or eliminate populations (McDonald 1955; Harris and Marshall 1963; Farney and Bookhout 1982; Grace and Wetzel 1982a; de Swart et al. 1994; van der Valk
1994; Kowalski and Wilcox 1999), and periodic low water levels with resultant low soil moisture can also hinder Typha (Urban et al. 1993; Wilcox et al. 2008). Typha has some tolerance to drought and can colonize wetlands under drought conditions (Swanson et al. 2003) provided soils have relatively low redox potential from sufficient periods of anoxia (Pezeshki et al. 1996). Hydrologic (e.g., water depth) variability tends to keep Typha under control (Boers and Zedler 2008). Lack of variability (e.g., due to water-level control) can reduce extremes and provide elevation zones where Typha is never stressed and can therefore form nearmonotypic stands (Shay et al. 1999; Wilcox et al. 2008). In addition, Typha invasion can be enhanced by hydrologic alterations that raise the water table and create wetter soil conditions (see Regional problems). Typha latifolia is often favored in shallower waters, while T. angustifolia, $T$. $\times$ glauca, and T. domingensis are better adapted to deeper waters (Grace and Harrison 1986; Grace 1988, 1989; Waters and Shay 1990, 1992; Weiner 1993), though it is not uncommon for multiple species of Typha to be found occupying the same wetland zones (Grace and Wetzel 1982b; McKenzie-Gopsill et al. 2012; Pieper et al. 2018).

\section{Chemistry}

Sediment and water chemistry strongly influence Typha growth and survival. Typha is often outcompeted by other aquatic macrophytes in low-nutrient, oligotrophic conditions (Newman et al. 1996; Currie et al. 2014). Increased nitrogen (N) and phosphorus $(\mathrm{P})$ concentrations in wetland waters due to fertilizer runoff from agricultural fields promote the growth of Typha, allowing it to proliferate aggressively in nutrientenriched freshwater wetlands and brackish salt marshes (Boyd and Hess 1970; Newman et al. 1996; Miao and Sklar 1998; Galatowitsch et al. 1999) (see Nutrients).

Typha's salt tolerance is generally lower than many halophytic aquatic macrophytes. Typha can be found in fresh, moderately brackish, and brackish but not highly saline waters (Stewart and Kantrud 1972; Beare and Zedler 1987; Zedler et al. 1990; Glenn et al. 1995). Typha's salt intolerance restricts it from occurring in the most saline marine environments (>30 ppt) (Crain et al. 2004) and inland saline wetlands (Swanson 1992). Typha angustifolia can tolerate more saline conditions than T. latifolia, while $T$. $\times$ glauca's salinity tolerance falls in between the two parental species (Stewart and Kantrud 1972; Wilcox 1986; Grace and Harrison 1986). Typha domingensis is three-times more tolerant of sulfide than Cladium in the Everglades (Li et al. 2009). Typha also can grow in soils contaminated with heavy metals (e.g., Al, As, $\mathrm{Cd}, \mathrm{Cr}, \mathrm{Cu}, \mathrm{Hg}, \mathrm{Mn}, \mathrm{Ni}, \mathrm{Pb}$, and $\mathrm{Zn}$ ) (Manios et al. 2003; Jacob and Otte 2004; Tang et al. 2005; Bonanno and Cirelli 2017) and has been used to remediate contaminated water and soils in natural and constructed wetlands (see Bioremediation) 
(Allen and Kleinmann 1991; Mbuligwe 2004; Cicek et al. 2006).

\section{Genetics}

Hybridization between native and non-native species or genotypes is one of the primary drivers behind the evolution of invasiveness (Arnold 1997; Ellstrand and Schierenbeck 2000), often closely following species introductions (Abbott 1992; Rhymer and Simberloff 1996). For T. $\times$ glauca, in the majority of cases, $T$. angustifolia is the maternal parent and T. latifolia is the paternal parent (Ball and Freeland 2013; Freeland et al. 2013). Recent research using chloroplast DNA (cpDNA) suggests that $T$. $\times$ glauca may be a threeway hybrid involving T. latifolia, T. angustifolia, and an introgressed cpDNA lineage from an unidentified Typha genotype (Freeland et al. 2017). Pollen morphology has been used to identify T. latifolia, T. angustifolia, and their hybrids (Finkelstein 2003; Lishawa et al. 2013; Marburger 2013).

Typha species and hybrids are most conclusively identified using nuclear DNA microsatellite markers and cpDNA, which is possible because some of these DNA markers are associated only with one or the other parental species (TsyuskoFreeland et al. 2017). Six species-diagnostic microsatellite loci were used in studies in seven US Great Lakes national parks (Travis et al. 2010; Marburger and Travis 2013). The results of genetic analysis of adult and seed bank Typha populations revealed that $\mathrm{F} 1$ hybrids (i.e., the first-generation offspring of pure Typha species, Fig. 3) can account for up to $99 \%$ of individuals. Other genetic studies have repeatedly found F1 hybrids throughout the northeastern and midwest regions of the US (Kirk et al. 2011; Freeland et al. 2013), as well as in California and possibly Florida (S. Travis, unpublished data; note that $T$. domingensis microsatellite alleles have yet to be characterized, with preliminary evidence suggesting size overlap with those of $T$. angustifolia).

Seed production can be affected by parental genotypes. When $T . \times$ glauca is pollinated by either parental species (referred to as 'backcrossing'; Fig. 3), seed production by $T . \times$ glauca offspring was relatively high. When $T . \times$ glauca was pollinated by other $T$. $\times$ glauca (referred to as 'advancedgeneration' or 'F2' hybrids), its seed production was $75 \%$ Omeltchenko et al. 2003; Snow et al. 2010; Kirk et al. 2011;

lower, indicating reduced hybrid fertility (Pieper et al. 2017). However, even with relatively low hybrid fertility, there are viable seeds that allow $T$. $\times$ glauca to proliferate and spread independent of its parental species.

\section{Competition and Hybrid Vigor}

In the parts of North America where T. angustifolia, T. latifolia, and $T . \times$ glauca overlap, $T . \times$ glauca dominates wetlands at the expense of both parental species (Travis et al. 2010; Kirk et al. 2011; Freeland et al. 2013), where it typically achieves much larger clone sizes (Travis et al. 2011), given that all three taxa can occupy similar habitat types (Olson et al. 2009; McKenzie-Gopsill et al. 2012; Zapfe and Freeland 2015; Pieper et al. 2018). The success of invasive hybrids can often be explained by heterosis, or hybrid vigor, which arises when hybrids have better fitness than parental species; there is some evidence for this in T. $\times$ glauca. For example, at one site in Ontario, Canada, T. latifolia was the tallest plant at the beginning of the growing season, but F1 hybrids quickly attained and maintained a greater height than either parental species (Zapfe and Freeland 2015). Similarly, common garden experiments found that hybrids outperformed $T$. latifolia in terms of total and aboveground biomass (BunburyBlanchette et al. 2015). Hybrids may also limit the fecundity of T. latifolia because hybrid pollination of T. latifolia stigmas by $T$. $\times$ glauca does not result in viable seeds (Pieper et al. 2017). Finally, $T . \times$ glauca produces copious leaf litter, which negatively affects the growth of competing plants (Vaccaro et al. 2009; Larkin et al. 2012a). Leachate from T. $\times$ glauca leaf litter also inhibits the germination of T. latifolia and T. angustifolia seeds while having no effect on $T$. $\times$ glauca seed germination (Szabo et al. 2018).

\section{Section 2: Regional Problems with Typha Invasion in North America}

The taxa of Typha in North America have expanded their range and abundance over the last $50-100$ years, particularly in regions such as the Laurentian Great Lakes (LGL), Florida Everglades, and midwestern Prairie Pothole Region (PPR; Fig. 4). Here, we present case studies from each of these three

Fig. 3 Pathways of hybrid T. $\times$ glauca formation between T. latifolia and T. angustifolia

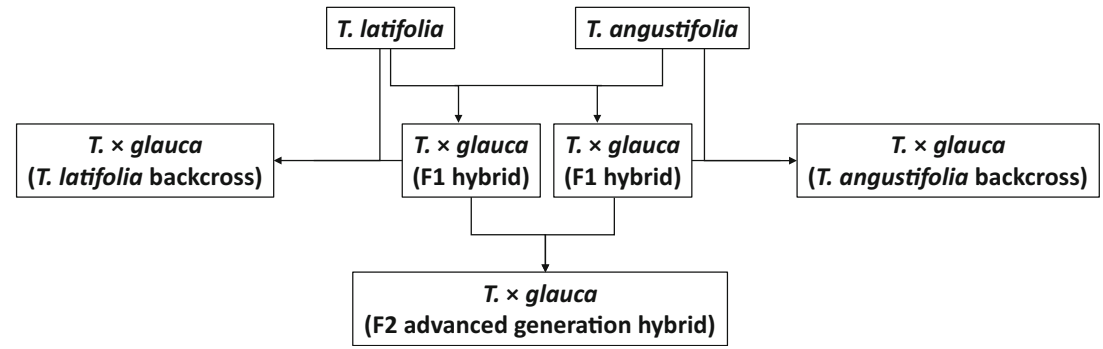


regions. The specific circumstances and timelines for expansion are unique to each region, albeit there are also common mechanistic drivers among regions. In particular, increased nutrient inputs into wetlands from agricultural runoff and disruption of natural hydrologic regimes are repeatedly identified as underlying drivers of Typha invasion. Corridors associated with roads and railroads, as well as boat travel, are also likely drivers of Typha expansion.

\section{Laurentian Great Lakes and Manitoba Coastal Wetlands}

\section{Historical Presence and Current Extent}

The Laurentian Great Lakes (LGL) region has thousands of kilometers of coastal lacustrine wetlands in the US and Canada that host a number of invasive plants, including Typha species. Three taxa of Typha occur in LGL wetlands: T. latifolia, T. angustifolia, and T. $\times$ glauca. While pollen records indicate that $T$. latifolia is native to eastern North America, pollen and herbarium records show increased abundance of T. latifolia, as well as westward invasion and proliferation by $T$. angustifolia, into LGL coastal wetlands beginning in the mid-1800s (Galatowitsch et al. 1999; Shih and Finkelstein 2008). The first known herbarium collection of T. angustifolia was from a Lake Ontario marsh in Oswego, New York, in 1880 (Wibbe 1880), followed by a Lake Erie coastal marsh in 1882 (Miller 1882), and a southern Lake Michigan coastal wetland in 1895 (Umbach 1895). Typha $\times$ glauca is largely missing from early herbarium records, most likely because hybridization was not widely recognized. However, T. $\times$ glauca occurred in LGL coastal wetlands at least since 1909, when its presence was documented at Illinois Beach on southern Lake Michigan (Gates 1912). Data from the Great Lakes Coastal Wetlands Monitoring Program illustrate the current extent of invasive Typha $(T . \times$ glauca and T. angustifolia) in the LGL. Between 2011 and
2013, invasive Typha were the dominant plant taxa in $13.5 \%$ of all LGL coastal wetland areas (Carson et al. 2018), where dominance is defined as $\geq 25 \%$ cover (Frieswyk et al. 2007). Lake Ontario has the highest level of invasive Typha dominance, at nearly $50 \%$ of wetland area, followed by Lake Erie (22\%), Lake Michigan (12\%), Lake Huron (6\%), and Lake Superior (1\%).

Similar to the LGL system, the large lakes in Manitoba Canada have also undergone widespread Typha invasion. Shay et al. (1999) used aerial photographs to map changes in vegetation types at specific sites in Delta Marsh of Lake Manitoba from 1948 to 1997 . They indicate invasion of the hybrid T. $\times$ glauca first occurred in Delta Marsh during a period following extensive flooding during the 1950s. Using historical aerial photography Grosshans (2001) constructed vegetation maps of the entire Delta Marsh and examined long-term changes in vegetation communities over a 36years period (1965-1997), documenting the considerable invasion of Typha throughout this coastal wetland system.

\section{Ecological Drivers of Typha Invasion}

Laurentian Great Lakes coastal wetlands are naturally dynamic ecosystems due primarily to variability in water levels over a range of time scales. Over decades, lake water levels vary by as much as $2 \mathrm{~m}$ (Gronewold et al. 2013), shifting the shallowsloping shorelines by up to several hundred meters and resulting in broad changes in soil inundation, wetland conditions, and vegetation zonation (Minc 1997; Albert et al. 2005). Laurentian Great Lakes wetlands typically consist of three water-level-mediated herbaceous vegetation zones: wet meadow, emergent marsh, and submergent marsh. Periodic waterlevel changes maintain plant diversity by disturbing successional trajectories and shifting the breadth, extent, and location of vegetation zones (Wilcox 2004). Following water-level retreat, wind-dispersed seeds and those in seed banks germinate on exposed mudflats (Keddy and Reznicek 1986), and long-

Fig. 4 Typha invasion has been particularly aggressive in North America in part due to nutrient enrichment from agricultural runoff and hydrologic stabilization: a the Laurentian Great Lakes Region, b the Florida Everglades, and $\mathbf{c}$ the midwestern Prairie Pothole Region

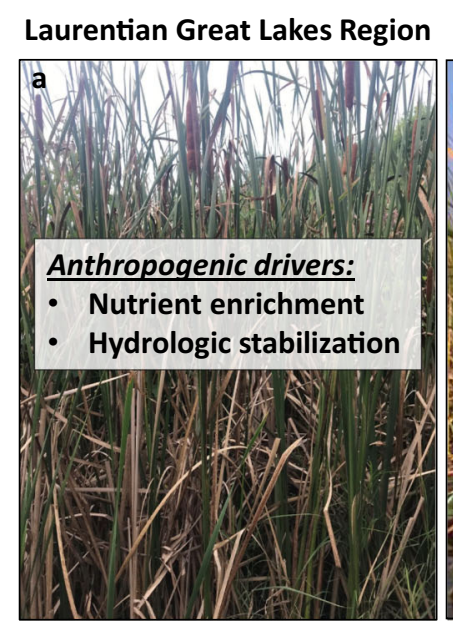

Everglades

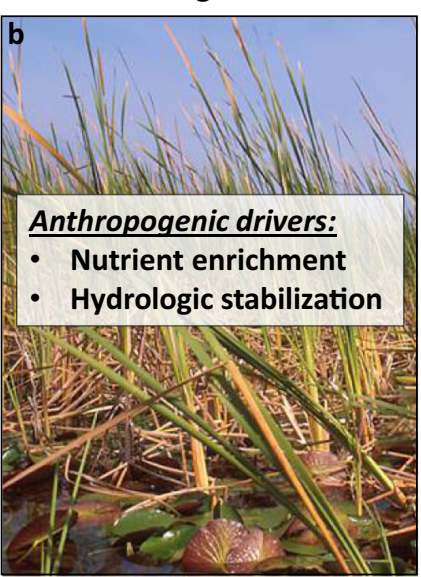

Prairie Pothole Region

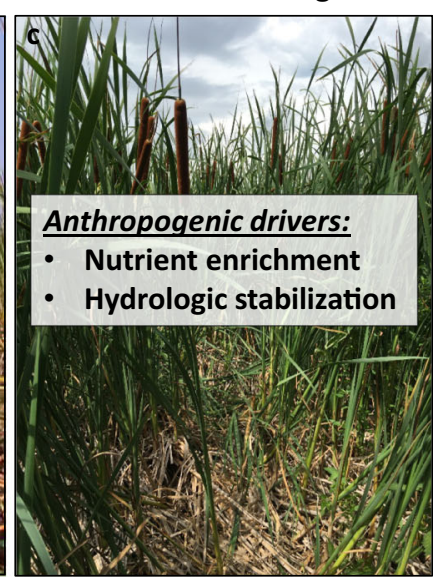


term persistent rhizomatous species emerge. In less perturbed LGL wetlands, T. latifolia typically persists as a subdominant plant-community member, occurring primarily at the margin between the emergent marsh and wet meadow communities. However, anthropogenic disturbances to natural nutrient and hydrologic regimes tend to favor invasive Typha over native plants in LGL wetlands.

Studies from around the LGL region have demonstrated that anthropogenic hydrologic disturbances enhance the competitive ability of Typha. Typha tolerates a wide range of water levels (Waters and Shay 1990; Bunbury-Blanchette et al. 2015), exhibiting increased competitive dominance under continuously-flooded conditions (Boers and Zedler 2008), prolonged low water levels (Lishawa et al. 2010), and when exposed to rapidly changing water levels (Hall and Zedler 2010). Reduced hydrologic variability and stabilized, aboveaverage water levels, resulting from water-level control on Lake Ontario, have resulted in increased dominance by invasive Typha and the widespread displacement of wet-meadow communities (Wilcox and Meeker 1995; Wilcox et al. 2008). In-depth studies of large-scale Typha invasion took place on Lake Ontario, which became a regulated reservoir beginning around 1960 following construction of the St. Lawrence Seaway (Wilcox and Meeker 1995; Hudon et al. 2006; Wilcox and Xie 2007; Wilcox et al. 2008; Wilcox and Xie 2008). The annual variability was reduced from 1.5 to $0.7 \mathrm{~m}$, and low lake levels during the growing season no longer occurred, even in years with low water supply. Detailed analyses of aerial photographs spanning a period from the 1950s-2001 showed that upslope wet meadows were continuously being lost to invasion by Typha (Wilcox et al. 2008). The results indicated that Typha invaded lakeward by forming floating mats, while landward invasion was more pervasive and occurred at the expense of grasses and sedges since sustained higher lake levels allowed Typha to outcompete sedges and grasses more tolerant of drier soil conditions. These findings corroborate those of Wilcox et al. (1984) in which vegetation types in the Cowles Bog Wetland Complex at Indiana Dunes National Lakeshore (adjacent to southern Lake Michigan) were mapped using aerial photographs from 1938 to 1982. They concluded that Typha invasion of sedge-grass meadow was promoted by continually wet conditions that resulted from seepage from a diked pond on adjacent lands. Stabilized high water levels have also been linked to increased dominance and faster rates of $T$. $\times$ glauca spread in interior Illinois (Boers et al. 2007) and Wisconsin wetlands, where $T$. $\times$ glauca clones can spread at rates of up to $4 \mathrm{~m}$ in diameter per year (Boers and Zedler 2008). Competitive dominants, such as Carex spp. (sedges), expand more slowly via vegetative growth and have reduced seedling survival under flooded conditions (Hall and Zedler 2010).

Similarly, in the Manitoba lakes, regulation of lake levels induced an expansion of Typha upgradient into Phragmites australis (common reed) communities and downgradient into open, shallow water. Extensive studies at Delta Marsh showed that Typha expanded in response to increasing and stable water levels (Waters and Shay 1990, 1992; Shay et al. 1999; Seabloom et al. 2001) and did so by vegetative growth from small colonies found in openings created by past extreme flooding (de Swart et al. 1994; Seabloom et al. 2001). At neighboring Lake Winnipeg, Grosshans et al. (2004) concluded that Typha invasion was partly related to lack of periodic low water levels following regulation of lake levels. Additionally, water-level control resulted in loss of emergent vegetation and erosion of uplands separating adjoining water bodies resulted in the amalgamation and expansion of marsh bays (Grosshans et al. 2004).

Plant communities tend to be more susceptible to invasions when disturbance to vegetation co-occurs with eutrophication (Burke and Grime 1996). This pattern holds in LGL and Manitoba coastal wetlands, where Typha tends to become dominant in hydrologically-disturbed and nutrient-enriched sites, such as within dikes (Thiet 2002; Herrick and Wolf 2005), where wetlands have been isolated from natural hydrologic variability and nutrient exchange with lakes (Mitsch 1992; Hill et al. 1998). Herrick and Wolf (2005) found that diked LGL wetlands had greater soil organic matter, plant available nutrients $(\mathrm{N}, \mathrm{P}$, potassium $[\mathrm{K}])$, and more than double the Typha cover than in paired, undiked wetlands (58.5\% vs. $21.7 \%$ ). Sustained flooding benefits Typha in part because under anoxic conditions, $\mathrm{P}$ becomes more biologically available (Young and Ross 2001), and Typha is able to use excess $\mathrm{N}$ and $\mathrm{P}$ more efficiently than native sedge and rush species that they displace (Woo and Zedler 2002; Larkin et al. 2012b). As such, Typha exhibits greater P retention and growth when persistently inundated (Boers and Zedler 2008). Prolonged low-water conditions have also been linked with increased presence and dominance of invasive Typha (Tulbure et al. 2007). These low-water effects have been documented even in otherwise-intact northern LGL coastal wetlands (Lishawa et al. 2010), likely due to increasing propagule pressure in the region. However, T. angustifolia stands were less robust after several low-water years, leading to lower stem density and invasion by herbaceous meadow and wetland tree species (Albert and Brown 2008). Extensive stands of $T$. angustifolia were also replaced by invasive $P$. australis in the southern LGL during the low-water period that began in 1999 (Albert and Brown 2008).

\section{Florida Everglades}

\section{Historical Presence and Current Extent}

The Everglades is a large, oligotrophic, subtropical wetland, covering approximately $7900 \mathrm{~km}^{2}$ in southern Florida (Light and Dineen 1994). It consists of a mosaic of plant 
communities that occur along topographic gradients from deepwater sloughs, to wet prairies, to Cladium-dominated communities, to marl prairies and tree islands (Davis and Ogden 1994; Gunderson 1994). Typha domingensis and T. latifolia are considered native in this landscape. While there are some references to $T$. angustifolia, multiple databases listing Typhaceae do not include Florida as within the range of T. angustifolia (Flora of North America 2000; Gann et al. 2001-2018; Wunderlin et al. 2018). As noted elsewhere, while artificial hybridization and putative field hybrids of $T$. domingensis and T. latifolia have been reported in California (Smith 1967), natural hybrids are found in few locations and are reportedly highly sterile (Flora of North America 2000). To date, there is no clear evidence of hybridization of these species in the Everglades, and in general, even intraspecific genetic variation within Typha populations is very low (Zhang et al. 2008).

Much of the documentation of Typha within the Everglades has focused on the northern and central parts of the ecosystem, where Typha is abundant on the periphery of the system (i.e., adjacent to canals; Fig. 5), especially in close proximity to inflow structures, but is generally sparse within the interior marsh (Rutchey et al. 2005; Rutchey et al. 2008; Gann and Richards 2014). For example, Typha relative abundance estimated using 400-m grids in Water Conservation Areas (WCAs) 1 and 2A, the two northernmost impoundments (Fig. 5), was 13\% (Gann and Richards 2014). More recently, Typha invasions have been documented in the southern Taylor Slough within Everglades National Park (Surratt et al. 2012). In 2014 , vegetation mapping within $63,1-\mathrm{km}^{2}$ sites throughout the Everglades landscape documented that Typha alone or Typha with C. jamaicense or shrubs occurred in $60 \%$ of the sites with cover ranging from $<1 \%, 1-5 \%$, and $5-26 \%$ in 37 , 45 , and $18 \%$ of the sites, respectively. While systemwide mapping of Typha has not been conducted for over a decade, there is evidence that in some areas the rate of expansion is declining in response to reductions in $\mathrm{P}$ loading to the Everglades (Rutchey et al. 2008; Zweig and Newman 2015). For example, in WCA-2A, the average annual rate of Typha expansion decreased from 961 ha $^{-1}$ during 1991-1995, to 312 ha $^{-1}$ during 1995-2003 (Rutchey et al. 2008).

\section{Ecological Drivers of Typha Invasion}

Everglades plant communities developed within a sub-tropical, rain-driven, flat carbonate system. As a result, most populations within the pristine Everglades are adapted to periodic fire, fluctuating hydroperiod, and low nutrient (specifically P) conditions (Davis 1943; Steward and Ornes 1983; Gunderson 1994; Richardson et al. 2008a). Low nutrient availability is not conducive to Typha species dominance, thus Typha in the undisturbed Everglades historically occurred as scattered diffuse stands (Davis 1994), with small pockets associated with nutrient-enriched areas such as wading-bird colonies or alligator holes. However, starting in the 1800 s, canals were dug within the northern Everglades to drain the peatlands for agriculture and provide flood control for urban development along the northern and eastern portions (Light and Dineen 1994). The remnant Everglades system is composed of impoundments, WCAs and Everglades National Park. Today, instead of the historical, rain-driven sheet flow, water moves through the ecosystem via approximately $3380 \mathrm{~km}$ of canals, $>1200$ culverts and water control structures, and 77 pump stations (South Florida Water Management District 2018). This altered hydrology has had a significant impact on the vegetation. Typha expanded into large areas of the Everglades primarily as a result of $\mathrm{P}$ enrichment from agricultural runoff (Urban et al. 1993; Davis 1994; Newman et al. 1996; Craft and Richardson 1997; Miao and Sklar 1998; Miao and DeBusk 1999; McCormick et al. 2002; Childers et al. 2003; Sklar et al. 2005; Noe and Childers 2007; Richardson 2008; McCormick et al. 2009). Typha has been able to outcompete other species due to its rapid growth rate and high plasticity that can take advantage of $\mathrm{P}$ enrichment (Lorenzen et al. 2001; Vymazal and Richardson 2003). By contrast, $C$. jamaicense, the dominant species of the Everglades ridge community, is adapted to low $\mathrm{P}$ conditions; $C$. jamaicense has high production of acid phosphatase extracellular enzymes for $\mathrm{P}$ acquisition under low $\mathrm{P}$ conditions (Lorenzen et al. 2001; Kuhn et al. 2002; Webb and Zhang 2013). The shape and arrangement of Typha invasion in a nutrientenriched portion of the northern Everglades tends to follow the pattern of historic sloughs (Fig. 5) (Rutchey and Vilchek 1999), suggesting that sloughs may be particularly susceptible because of the deeper water and low stature, predominantly floating-leaved vegetation (McCormick et al. 2009). In addition, upon nutrient enrichment in sloughs, the native floating periphyton disappears, and remnant communities have low biomass due to shading created by tall, dense Typha stands (McCormick et al. 1997; Vaithiyanathan and Richardson 1999; Gaiser et al. 2005; Gaiser et al. 2011; Hagerthey et al. 2011).

Disturbances, such as changes in hydrology, overdrainage, or fire, also provide a competitive advantage to $T$. domingensis in the peat-based Everglades system (Gunderson 1994; Newman et al. 1998; Miao et al. 2001; Smith and Newman 2001; Smith et al. 2001; Richardson 2008; Tian et al. 2010; Wu et al. 2012). Increased water depth (Newman et al. 1996) and flooding duration (Urban et al. 1993) allow T. domingensis to outcompete $C$. jamaicense. Typha aboveground tissues conduct pressurized bulk air flow during the day (Chanton et al. 1993) that oxygenates its rhizosphere (Chabbi et al. 2000) and enables it to withstand the reduced conditions caused by flooding. In drained conditions, however, T. domingensis expansion results from soil oxidation, which can result in P release (Newman et al. 1998). 


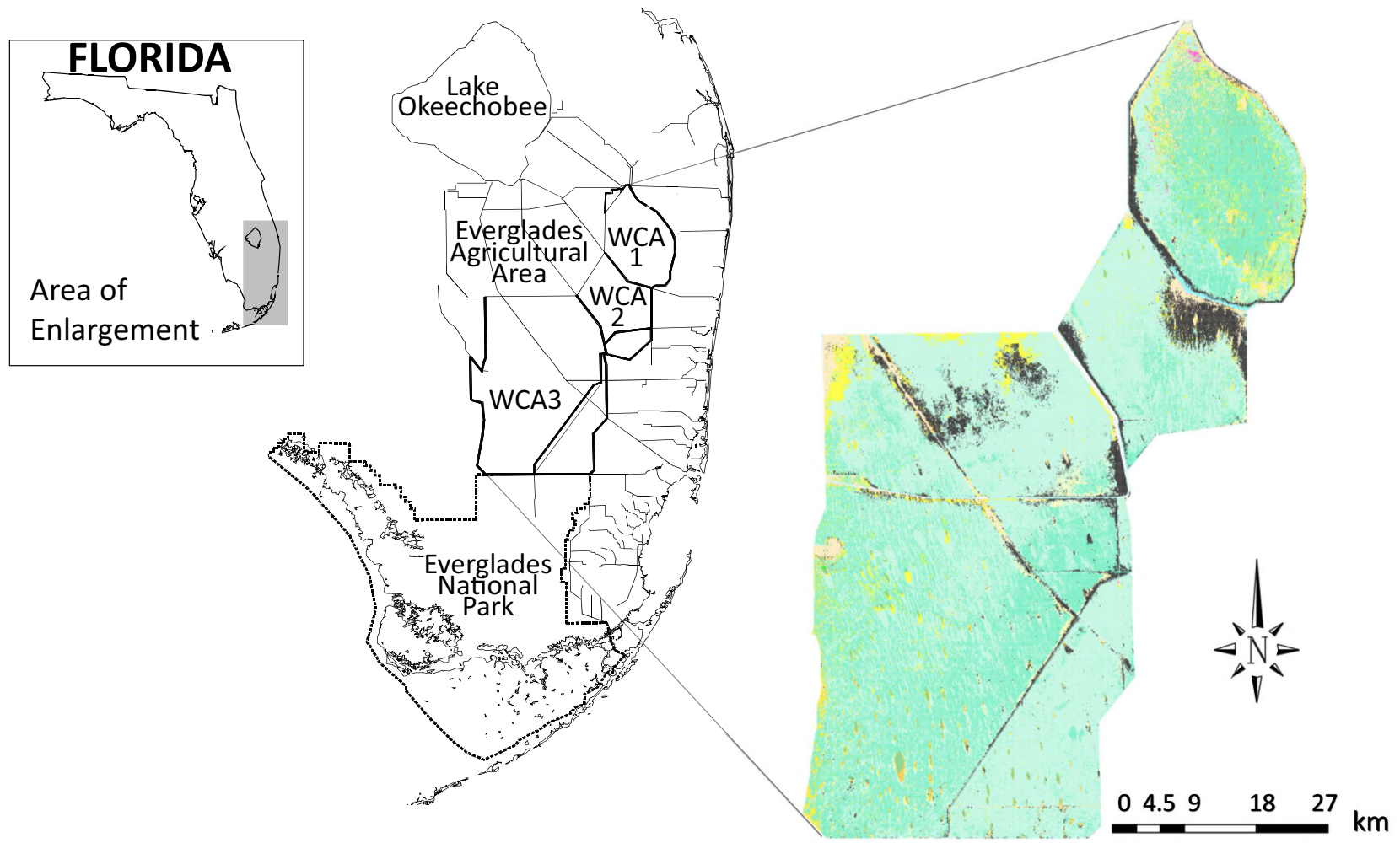

Fig. 5 The spatial extent of Typha (black shading) throughout the northern and central Everglades observed in 2003-2004 (Rutchey et al. 2008; Sklar et al. 2009, 2011). Note the extensive Typha coverage adjacent to canal systems

Similarly, both peat burns and surface vegetation burns promote $T$. domingensis expansion through the release of bioavailable $\mathrm{P}$ (peat burn only) and the creation of openings that alleviate competition and create opportunities for invasion (Smith and Newman 2001; Richardson et al. 2008a; Richardson et al. 2008b). Typha domingensis invasion has historically occurred in the north-central Everglades (i.e., WCAs, Fig. 5). Detailed north-to-south transects in WCA2A from 1990 until 2002 showed that $T$. domingensis densities were dominant in the more eutrophic sites close to canal $\mathrm{P}$ loadings, while $C$. jamaicense dominated less-impacted or oligotrophic sites further in the interior away from the canals (Miao and Sklar 1998; Richardson 2008).

Once established, Typha dominance can be maintained for prolonged periods, even when nutrient loads to the system are reduced. With roots predominantly within the upper $20 \mathrm{~cm}$ (Miao and Sklar 1998) but extending deeper, Typha is able to 'mine' legacy $\mathrm{P}$ in nutrient-enriched soils, translocating $\mathrm{P}$ from soils back into the water column; such mining presents a long-term source of $\mathrm{P}$ even after reductions in $\mathrm{P}$ loading into the Everglades (Noe and Childers 2007; Richardson et al. 2008b). In addition, the rapid growth of Typha in nutrientenriched areas results in the rapid accumulation of peat
(0.5- $\rightarrow 1 \mathrm{~cm} \mathrm{y}^{-1}$ compared to $\sim 1 \mathrm{~mm} \mathrm{yr}^{-1}$ in unenriched areas (Reddy et al. 1993; Craft and Richardson 1997). This in turn creates higher elevations that are more susceptible to drying and more favorable to transitional wetland species such as Salix caroliniana (coastal plain willow).

\section{The Prairie Pothole Region}

\section{Historical Presence and Current Extent}

The Prairie Pothole Region (PPR) contains millions of shallow, depressional wetlands, commonly referred to as 'potholes,' which are nested within a cropland and grassland matrix (Euliss et al. 2006; Badiou et al. 2011; Dahl 2014). Potholes generally are classified as palustrine emergent wetlands with periods of inundation ranging from ephemeral to permanent (Stewart and Kantrud 1971; Cowardin et al. 1979), mean water depths ranging from less than 0.5-2 m (Stewart and Kantrud 1972; Dahl 2014; Tangen et al. 2015), and salinities ranging from fresh to hypersaline (Stewart and Kantrud 1972; Swanson et al. 1988; LaBaugh 1989; Euliss et al. 2014; Goldhaber et al. 2014; Mushet et al. 2015a). 
According to historical accounts and reviews, Typha was not prominent in the PPR prior to the mid-twentieth century (Kantrud 1986, 1992; Sojda and Solberg 1993; Galatowitsch et al. 1999). In the North Dakota State University (NDSU) Herbarium, the earliest collection of T. latifolia in North Dakota was in 1891, and seven additional collections were made from 1906 to 1912 (Dekeyser, NDSU Herbarium Curator, pers. obs). The first collection of T. angustifolia was in 1942, and the first verified specimen of $T$. $\times$ glauca was in 1963. Since that time, Typha has become ubiquitous throughout the region (Stewart and Kantrud 1972; Kantrud 1986; Ralston et al. 2007; Safratowich et al. 2008; Post van der Burg et al. 2014). Potholes have been associated with T. angustifolia and T. latifolia, and T. $\times$ glauca has become dominant in many areas (Stewart and Kantrud 1971, 1972; Kantrud 1986). In the North Dakota portion of the PPR, Ralston et al. (2007) showed that 23-49\% of wetlands surveyed contained Typha depending on location in the PPR. Also, Ralston et al. (2007) suggested that wetlands with Typha were, on average, larger than the wetlands without Typha and that Typha covered 37\% of individual wetlands.

\section{Ecological Drivers of Typha Invasion}

In their natural state, PPR wetlands are characterized by dynamic vegetation zones, which are composed of distinct plant communities that fluctuate seasonally, as well as with wet and dry annual cycles (Euliss et al. 2004; van der Valk 2005; Euliss and Mushet 2011). These dynamic shifts between inundated and dry conditions generally do not favor establishment and persistence of dominant, monotypic vegetation communities. Historic grazing and wildfire regimes of prairie ecosystems also precluded establishment of such vegetation communities.

Natural disturbances, such as grazing and fire that preclude Typha, are no longer prominent in many areas, while anthropogenic disturbances such as tillage, siltation, and drainage result in environments where Typha flourishes (Kantrud 1986; Swanson and Duebbert 1989; Gleason and Euliss 1998; Anteau 2012; Wiltermuth and Anteau 2016). Many potholes exist within agricultural fields where they can receive nutrient and sediment inputs that promote the spread of Typha (Martin and Hartman 1987; Wang et al. 1994; Kantrud and Newton 1996; Gleason and Euliss 1998; Werner and Zedler 2002; Woo and Zedler 2002; Tangen et al. 2015). Sedimentation can inhibit seed germination of other species and reduce water depths of potholes (sediment filling) so that they no longer exceed depths that are detrimental to Typha (Jurik et al. 1994; Wang et al. 1994; Gleason and Euliss 1998). Soil structure and hydrology of a wetland can be considerably modified by sedimentation via a decrease in soil organic matter and an increase in soil bulk density (Werner and Zedler 2002), which favor Typha over native species. Wetlands in a cropland matrix also can receive greater inputs of precipitation runoff, resulting in lengthened periods of the saturated or moist-soil conditions preferred by Typha (Euliss and Mushet 1996; van der Kamp et al. 2003). Lastly, while salinity of potholes varies greatly across spatial and temporal scales, the majority of wetlands fall within ranges that support Typha (Stewart and Kantrud 1971, 1972; Ralston et al. 2007; Gleason et al. 2009); and recent wetting of potholes in response to increased precipitation inputs (Mushet et al. 2015b) has likely increased the number capable of supporting Typha.

Wetlands of the PPR landscape exist in intermittentlyconnected watersheds characterized by smaller, more ephemeral wetlands in the upper parts of the watershed and larger, more permanent wetlands in the lower parts of the watershed (McCauley and Anteau 2014; Hayashi et al. 2016). Demand to increase agricultural production has motivated the drainage of many PPR wetlands, which has been particularly focused on the drainage of smaller, more ephemeral wetlands (Dahl 1990) into larger wetlands through either surface ditches or subsurface drainage systems (i.e., 'consolidation drainage') (Krapu et al. 2004; Anteau 2012; McCauley et al. 2015). Wetlands that receive drainage water have markedly greater and more stable water levels than they did before drainage (Wiltermuth 2014; McCauley et al. 2015; Anteau et al. 2016). Additionally, the PPR has experienced recordhigh water levels since the mid-1990s due to changes in climate and weather patterns, increasing the amount of water entering wetlands even in areas that do not have a large degree of consolidation drainage (Anteau et al. 2016; McKenna et al. 2017). These effects of land use and climate have a synergistic interaction that increases water levels of basins until they stabilize at their basin spill point (McCauley et al. 2015; Anteau et al. 2016; Post van der Burg et al. 2016). While increases in water level can reduce Typha abundance in the short term, the eventual stabilized conditions can promote proliferation of Typha over time (Shay et al. 1999; Euliss et al. 2004; Anteau 2012; Wiltermuth and Anteau 2016).

\section{Section 3: Ecological, Biogeochemical and Agricultural Impacts of Typha Invasion}

The invasion and subsequent dominance of wetlands by invasive Typha result in predictable patterns of change at nearly all trophic levels in wetland ecosystems (Angeloni et al. 2006; Mitchell et al. 2011; Lishawa et al. 2013; Lishawa et al. 2014; Lishawa et al. 2017) (Fig. 6). 

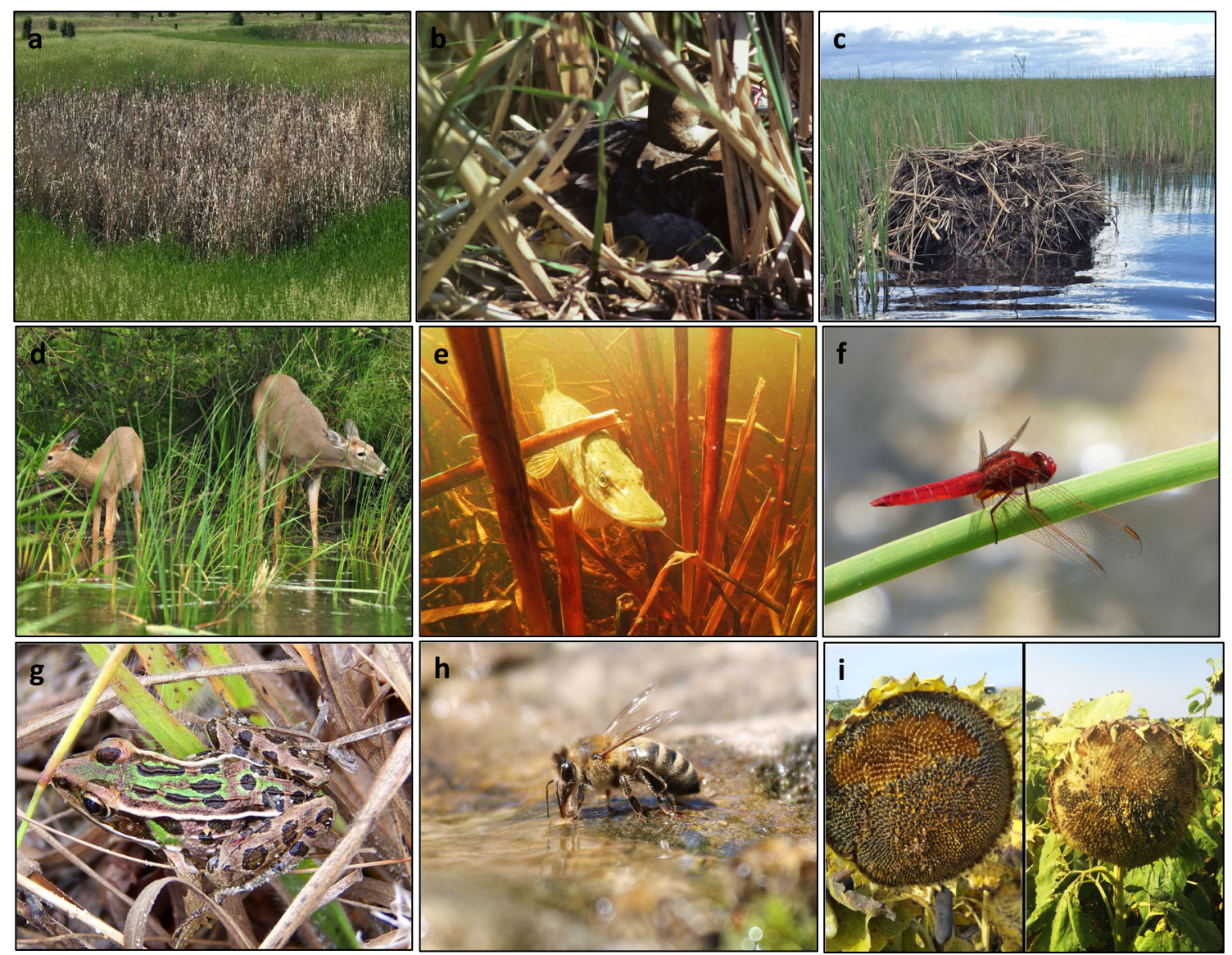

Fig. 6 Typha invasion impacts nearly all trophic levels in and around wetland ecosystems: a native vegetation - standing dead Typha from previous years' growth forms dense cover that inhibits competing plant establishment; b waterbird breeding habitat - Canvasback (Aythya valisineria) nesting in Typha; $\mathbf{c}$ muskrat den building material; $\mathbf{d}$ deer cover; e northern pike spawning habitat; $\mathbf{f}$ invertebrate habitat; $\mathbf{g}$ amphibian habitat; $\mathbf{h}$ pollinator habitat; $\mathbf{i}$ agriculture - sunflower damage from blackbirds that roost in Typha stands

\section{Flora and Fauna}

\section{Plants}

Invasive Typha dominance impacts the diversity and abundance of a range of native taxa, decreasing plant diversity (Frieswyk and Zedler 2007; Wilcox et al. 2008; Farrer and Goldberg 2009; Tuchman et al. 2009), altering plantcommunity structure (Grosshans et al. 2004; Lishawa et al. 2010), and modifying the physical structure of vegetation (Lishawa et al. 2017). Both direct and indirect mechanisms are responsible for the displacement of native plant species by invasive Typha. Directly, Typha has higher rates of primary productivity (Tuchman et al. 2009) and more efficient use of excess nutrients (Woo and Zedler 2002; Larkin et al. 2012b), conferring competitive dominance over native sedges. Indirectly, standing-dead leaf litter in Typha stands accumulates to the detriment of native species, while minimally affecting Typha growth rates (Farrer and Goldberg 2009; Tuchman et al. 2009; Vaccaro et al. 2009; Mitchell et al. 2011; Larkin et al. 2012a) (Fig. 6a)., except when litter was experimentally applied to a depth of $50 \mathrm{~cm}$, which caused a decreased in Typha productivity (Jordan et al. 1990).

Data collected from stand-age gradients in the field and from long-term mesocosm experiments indicate that, with increasing stand-age, litter mass and cover, Typha density, soil organic matter, organic sediment depth, and soil denitrification potential tend to increase, while plant species richness and evenness decrease (Mitchell et al. 2011; Lishawa et al. 2014). Thus, time since a site has been invaded serves as a useful proxy for degradation of the system and its potential for restoration.

\section{Waterfowl and Wildlife}

Dense stands of Typha eliminate open-water zones and replace other emergent species and submerged aquatic species (Kantrud 1992; Cressey 2016; Lawrence et al. 2016a). Typha impacts wildlife principally by displacing forageproducing plants and altering vegetative structure that many wildlife species are dependent upon (Kantrud 1986). 
Prior to the invasion of Typha, communities of emergent annual and perennial plants that occupy less permanently ponded parts of wetlands typically have greater diversity (e.g., Polygonum [knotweed], Carex, Eleocharis [spikerush], Scirpus spp. [bulrush], Schoenoplectus [bulrush]) (Kantrud 1986; Weller 1988; Cressey 2016). These emergent plants produce great densities of seeds that are consumed by many waterbird species (Krapu and Reinecke 1992; Haukos and Smith 1993; Dugger et al. 2007; Greer et al. 2007; Hagy and Kaminski 2012). In contrast, Typha seeds are very small and not considered a wildlife food. Typha also expands into more permanently ponded parts of wetlands that typically have submerged, aquaticvegetation communities. Seeds, tubers, and vegetation of submerged aquatic vegetation are energy-rich forage for many waterbirds, especially waterfowl (Krapu and Reinecke 1992). Additionally, submerged aquatic vegetation also provides ideal habitat for many aquatic-macroinvertebrate species that various waterbird species consume (Krapu and Reinecke 1992; Anteau et al. 2011; Anteau 2012).

Relative to Typha, many of the displaced emergent species are shorter with much smaller diameter stems, which provides adequate overhead cover for nesting and secretive marsh waterbirds while still allowing movement within the canopy (Kantrud 1986). For example, Typha is less preferred by waterbirds than bulrushes, which have smaller diameter stems and lower stem densities that allow swimming and flushing escape (Low 1945; Mack and Flake 1980; Raven et al. 2007) (Fig. 6b). In many cases, dense Typha stands quickly fill wetland basins, precluding most waterbird use and reducing the length of time a wetland can exist in the waterfowl-optimal hemi-marsh condition (Kantrud 1986, 1992; Sojda and Solberg 1993; Solberg and Higgins 1993; Linz et al. 1996a, b; Linz and Blixt 1997). While secretive marsh birds are often associated with dense stands of Typha, most species require a more varied habitat structure not present in Typha-dominated systems (Johnson and Dinsmore 1986; Linz et al. 1997; Rehm and Baldassarre 2007; Hill 2017).

Typha provide abundant forage and den construction material for muskrats (Ondatra zibethicus; Fig. 6c), and Typha dynamics have been linked to muskrat population trends (Errington 1939; Weller 1988; Kantrud 1992). Additionally, the dense cover of Typha provides excellent hiding and thermal cover for white-tailed deer (Odocoileus virginianus; Fig. 6d), pheasants (Phasianus colchicus), and invasive wild boar (Sus scrofa), which helps support their populations in highly agricultural landscapes that may have limited tree and shrub cover (Fritzell 1989; Kantrud 1992; Homan et al. 2000; Homan et al. 2003).

\section{Fishes}

The tendency for invasive Typha to grow in dense, homogeneous stands and reduce native plant diversity (Frieswyk and
Zedler 2007; Wilcox et al. 2008; Tuchman et al. 2009; Lishawa et al. 2010) can negatively affect fish communities (Smokorowski and Pratt 2007; Hagerthey et al. 2014). Diverse plant assemblages and heterogeneous plant growth forms found in native marsh habitats tend to result in increased diversity and species richness of larval (Höök et al. 2001; Tanner et al. 2004), juvenile, and adult fish communities (Tonn and Magnuson 1982), and the increased growth and survival of fishes (Olson et al. 1998). Invasive Typha stands contain fewer submergent plant species with highly dissected leaves and fewer floating-leaved plants compared to native marsh areas (Lawrence et al. 2016a), reducing options for cover and foraging for fishes. For example, foraging by ambush predators such as largemouth bass (Micropterus salmoides), northern pike (Esox lucius), or Florida gar (Lepisosteus platyrhinchus) may be negatively affected by the increased stem density and reduced heterogeneity of Typha stands (Hagerthey et al. 2014; Trebitz and Hoffman 2015).

The conversion of native coastal marsh habitat to a Typha monoculture can reduce the utility of these areas as spawning sites for economically important fish species. For example, in the Upper St. Lawrence River, Typha invasion replaced native sedge species, thereby reducing northern pike (Fig. 6e) spawning habitat and causing overlap in pike and muskellunge (Esox masquinongy) spawning sites (Cooper et al. 2008). Furthermore, the increase in stem density and litter caused by Typha can reduce water column dissolved oxygen, making these spawning grounds inhospitable as nursery and rearing areas for larval and juvenile fishes (Bunch et al. 2010; Hagerthey et al. 2014; Bunch et al. 2015). Though dense Typha stands can be suboptimal for some fish species, when combined with differences in nutrient levels, Turner et al. (1999) observed higher fish biomass in nutrient-enriched Typha areas compared to oligotrophic areas dominated by native plant species in the Everglades.

\section{Invertebrates}

Typha invasion can alter aquatic-invertebrate communities (Fig. 6f) by reducing structural complexity as heterogeneous, native marshes are converted to areas dominated by dense, thick-stemmed Typha that produces copious litter (Krecker 1939; Farrer and Goldberg 2009; Lawrence et al. 2016a). Macroinvertebrates, however, have been shown to colonize Typha litter and often display varied responses to vegetation communities (Nelson et al. 1990b; Batzer 2013; Yozzo and Osgood 2013). In P-enriched areas of the Florida Everglades King and Richardson (2007) concluded that Typha growth effected periphyton and the aquatic invertebrates that rely on it as a food source. Lawrence et al. (2016a) found that in Great Lakes coastal wetlands, invasive Typha plots had reduced submerged and floating-leaved plant species diversity 
compared to native marsh plots, which corresponded with a decrease in macroinvertebrate biomass and density. These data suggest that increasing habitat heterogeneity by reducing the abundance of Typha (Cardinale et al. 1997) may increase macroinvertebrate biomass, thereby improving habitat for higher trophic levels such as birds (Kostecke et al. 2005). For example, Schummer et al. (2012) found increased macroinvertebrate abundance in dredged ponds within Lake Erie coastal wetlands compared to Typha-dominated areas. In addition to homogenizing habitat, the abundant litter produced by Typha can result in hypoxia, reducing macroinvertebrate abundance and causing shifts in macroinvertebrate communities (Rose and Crumpton 1996; Christensen and Crumpton 2010). Similar to data for fishes, when Typha presence was combined with nutrient differences, McCormick et al. (2004) documented a significant increase in macroinvertebrate densities in P-enriched Typha stands compared to unenriched sites when using sweep nets to collect data. However, the same study found the opposite result when using different sampling devices, i.e., Hester Dendy samplers, demonstrating the effects of sampling protocol and challenges in this field of research.

Crayfish seem to show a different pattern in response to Typha invasion compared to other invertebrate taxa. For example, in the nutrient-enriched Everglades, Typha-dominated plots had the greatest density and biomass of crayfish (Procambarus fallax) compared to plots where Typha was removed (Hagerthey et al. 2014). Similarly, in Great Lakes coastal wetlands, crayfish (Orconectes spp.) abundance was lower in native-marsh sites compared to Typha-invaded sites (A. Schrank, unpublished data). It is unknown whether absence of crayfish in native-marsh sites is a result of increased predation by more abundant fish predators or habitat preference by crayfish.

\section{Amphibians}

Amphibians are key components of wetland food webs as they uniquely rely on both aquatic and terrestrial habitats within their lifetimes, and transfer a significant quantity of nutrients across the aquatic-terrestrial boundary (Brazner et al. 2007) (Fig. 6g). Amphibians are widely used as bioindicators because many species are sensitive to changes in physical and chemical habitats, including non-native plant species invasions (Mifsud 2014). Dense stands of invasive Typha have the potential to negatively affect amphibians by increasing marsh desiccation and reducing and fragmenting habitat for reproduction, larval development, and movement and migration (Meyer 2003; Perez et al. 2013; Mifsud 2014). Although studies of Typha effects on amphibians are limited, negative correlations between dense stands of invasive $P$. australis and amphibian species richness have been documented (Meyer 2003; Mifsud 2014). Amphibians are likely unable to move as effectively through dense stems of $P$. australis, and amphibians in Typha would be similarly challenged due to the structural similarity. Perez et al. (2013) found that dense stands of $P$. australis slowed larval development of juvenile wood frogs (Lithobates sylvaticus), although the mechanism for this was not clear. It has also been suggested that the high carbon:nitrogen:phosphorus ratio and consequent slow decomposition rate of Typha litter may negatively affect frog larvae (Stephens et al. 2013). Finally, invaded wetlands are commonly managed via herbicide and/or burning (Linz and Homan 2011; Svedarsky et al. 2016), which can negatively affect amphibians (Russell et al. 1999; Howe et al. 2004).

\section{Pollinators}

Bees and other insects play a critical role in pollination and maintaining ecosystem function (Ollerton et al. 2011; Calderone 2012) (Fig. 6h). The importance of wetlands in supporting bee diversity and forage plants has only recently been studied (Smart et al. 2017; Stephenson 2017), and the effects of invasive Typha on bee populations are largely unknown. Spread of invasive plants into native habitats has the potential to negatively affect bee populations through reduction in native flower diversity and flower fitness (Larson et al. 2006; Larson et al. 2014). In general, homogenization of habitat caused by invasive species is likely to have the greatest effect on bee species that have narrow and specialized pollen diets (e.g., oligolectic bees). Although bees will readily collect pollen from Typha (Smart et al. 2017), Typha pollen has limited nutritional value and may be toxic to bees (Schmidt et al. 1989). Honey bees fed Typha pollen have reduced survival relative to those fed pollen from other plants (Schmidt et al. 1987). In the Northern Great Plains, beekeepers favor areas with wetlands when selecting locations to keep honey bee colonies for the summer, presumably because wetlands support flowering plants throughout the growing season and provide water sources to foraging bees (Gallant et al. 2014; Otto et al. 2016).

\section{Nutrients}

Typha invasion magnifies $\mathrm{N}$ and $\mathrm{P}$ availability and biogeochemical cycling in wetlands (Fig. 7a). Feedbacks between enhanced nutrient availability and Typha invasion can complicate interpretation of field observations when evaluating cause and effect of this pattern. Most studies point to elevated nutrients facilitating Typha invasion, which then leads to further changes in ecosystem nutrient cycling due to the characteristics of Typha (Farrer and Goldberg 2009; Currie et al. 2014).

Typha invasion is associated with increased sediment deposition in wetlands, which accelerates inputs of sediment-attached $\mathrm{N}$ and $\mathrm{P}$. Typha domingensis and 


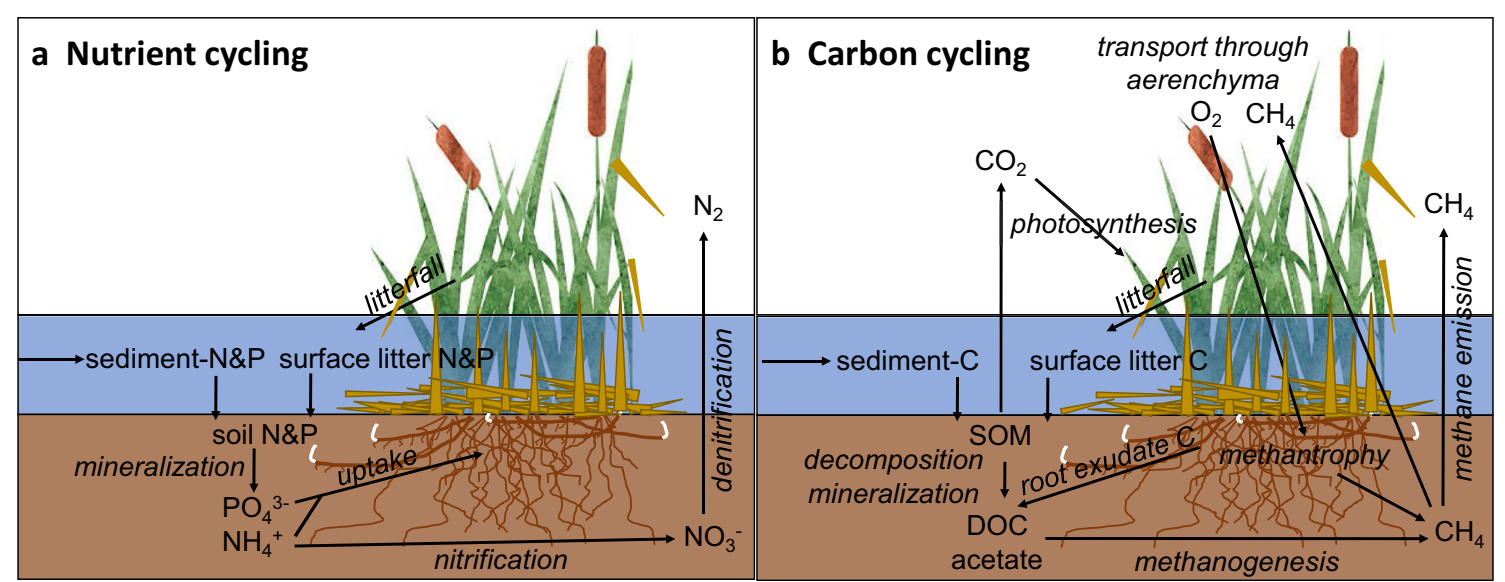

Fig. 7 Typha affects many biogeochemical processes including a nutrient and $\mathbf{b}$ carbon cycling

T. angustifolia both increase sedimentation and associated nutrient deposition (Horppila and Nurminen 2001; Anderson and Mitsch 2006). Typha $\times$ glauca is also associated with areas of greater sedimentation in wetlands (Werner and Zedler 2002). Both increased deposition and the accumulated organic matter left after litter decomposition can raise the soil surface relative to the water table (Kirschner et al. 2001), resulting in further alteration of nutrient cycles.

Invasive $T$. $\times$ glauca amplifies internal nutrient cycling in wetland ecosystems (Currie et al. 2014). Much higher concentrations of extractable nitrate, ammonium, and phosphate are commonly found in soils of $T . \times$ glauca patches in marshes it has invaded (Angeloni et al. 2006; Farrer and Goldberg 2009; Tuchman et al. 2009; Lishawa et al. 2010; Geddes et al. 2014; Lishawa et al. 2014). Typha $\times$ glauca has greater nutrient uptake rates than native wetland plants (Larkin et al. 2012b), leading to increases in N and P concentrations (Woo and Zedler 2002) and standing stock (Boers and Zedler 2008) in T. $\times$ glauca after nutrient fertilization. In the Everglades, T. dom ingensis is capable of accessing legacy $\mathrm{P}$ in nutrientenriched soils even after $\mathrm{P}$ input into the system has been decreased (Noe and Childers 2007; Richardson et al. 2008 b). Increases in above-ground plant nutrient uptake and concentrations are greater for invading $T$. domingensis than for native sedges in the Everglades, but no differences in nutrient resorption proficiency typically occur (Davis 1991; Newman et al. 1996; Noe et al. 2001; Childers et al. 2003; Miao 2004; Noe and Childers 2007). The elevated $\mathrm{N}$ concentrations and greater biomass production of T. $\times$ glauca also result in greater ecosystem $\mathrm{N}$ retention (Currie et al. 2014). Yet, when invasive Typha is treated with herbicide to meet management objectives, decreased plant demand results in increased soil inorganic nutrient availability (Lawrence et al. 2016b; Elgersma et al. 2017), which may set the stage for reinvasion, algal blooms, or export of nutrients to adjacent aquatic systems. Nutrient release is of particular concern in ecosystems such as the Everglades, where downstream ecosystems are oligotrophic.

Typha invasion also affects soil-nutrient biogeochemistry through its production of large amounts of detritus. Only the litter of $T . \times$ glauca, and not live plants, increased soil $\mathrm{N}$ mineralization rates and extractable ammonium concentrations in a transplant experiment (Farrer and Goldberg 2009). Phosphorus enrichment, which led to $T$. domingensis invasion, also stimulated soil P availability (Rejmánková 2001) and $\mathrm{N}$ mineralization (White and Reddy 2000). Typha $\times$ glauca was able to utilize $\mathrm{N}$ from its own litter more than co-occurring native plants could (Larkin et al. 2012b). Typha domingensis litter immobilizes more $\mathrm{N}$ and $\mathrm{P}$ during decomposition than native sedges (Davis 1991). Nutrient and litter manipulations suggested that the physical structure of T. angustifolia litter was a key factor in nutrient cycling, rather than decomposition (Jordan et al. 1989; Jordan et al. 1990). In a brackish tidal marsh, $T$. angustifolia litter minimized the stimulation of sediment $\mathrm{N}$ and $\mathrm{P}$ concentrations in response to experimental fertilization through some physical mechanism, perhaps shading that cooled the soil (Jordan et al. 1989).

Finally, soil denitrification is altered by Typha invasion. The soil under $T$. $\times$ glauca has greater denitrification gene diversity but not gene abundance (Angeloni et al. 2006; Geddes et al. 2014). Greater denitrification potential rates are associated with Typha in constructed wastewater treatment wetlands (Chen et al. 2014) and in natural wetlands invaded by $T$. $\times$ glauca, although there are variable patterns of change in denitrification with age since invasion (Geddes et al. 2014; Lishawa et al. 2014). Because denitrification is a valuable ecosystem service that removes reactive $\mathrm{N}$ from the biosphere and improves water quality, enhanced rates of denitrification that result from Typha invasion should be weighed against other ecosystem services that may be impaired by invasion (Lishawa et al. 2014). 


\section{Carbon and Greenhouse Gases}

Despite extensive work investigating carbon (C) cycling associated with wetland plant communities, few studies have explicitly examined effects of Typha invasion. Understanding invasion impacts on C-related processes is challenging because Typha invasion and the wetland $\mathrm{C}$ cycle are both sensitive to changes in hydrology and nutrient additions, making it difficult to establish causality in observational studies. For example, nutrient additions can simultaneously facilitate Typha invasion and strongly increase soil organic matter (SOM) (Martina et al. 2014), creating the impression that Typha increases SOM. Further, the relative impact of invasion is also a function of the species that are replaced. Here, we draw on studies that explicitly examined Typha invasion impacts on C-related processes, as well as those that addressed the underlying mechanisms associated with Typha invasion (Fig. 7b).

Due to traits associated with resource acquisition (i.e., growing tall, producing large amounts of aboveground and root belowground biomass), plant invasions tend to enrich SOM and increase $\mathrm{C}$ storage in plant, litter, and microbial biomass pools (Liao et al. 2008; Ehrenfeld 2010; Vilà et al. 2011). Typha conforms to this syndrome, as Typha-invaded stands tend to be more productive and taller than the species they replace. In the LGL, $T . \times$ glauca produces $\sim 2$ times as much aboveground biomass as the native sedge- and rushdominated communities it typically replaces (Lawrence et al. 2017), and T. domingensis in the Everglades tends to be $\sim 1.5$ times taller than the native sawgrass it outcompetes (Miao and Sklar 1998). Since Typha's high primary productivity promotes $\mathrm{CO}_{2}$ uptake while anoxic soils slow down $\mathrm{CO}_{2}$ release via decomposition and other heterotrophic processes, $\mathrm{C}$ tends to accumulate in surface litter and soils in Typha-invaded wetlands; this has been documented in paleoecological studies of Typha-dominated marsh sites (e.g., Finkelstein et al. 2005). Surface litter can accumulate rapidly when Typha invades due to high aboveground biomass production coupled with relatively slow decomposition rates, largely due to a prolonged standing dead phase (Davis and van der Valk 1978; Vaccaro et al. 2009). For example, litter mass doubled within 10 years of Typha invasion in a Lake Michigan coastal wetland (Mitchell et al. 2011). Standing dead and surface litter can account for one-half to two-thirds (600-2500 $\mathrm{g}_{\text {litter }}{ }^{-2}$ ) of the total aboveground biomass in established Typha stands (Childers et al. 2003; Vaccaro et al. 2009), representing a large $\mathrm{C}$ pool. High rates of nutrient resorption also promote $\mathrm{C}$ storage; by examining three co-occurring wetland invaders, Martina et al. (2014) demonstrated that it is the combination of a large quantity and low quality of litter that promotes $\mathrm{C}$ accretion under Typha. In a mesocosm experiment, Lawrence et al. (2017) found that the percentage of soil C doubled after 10 years of invasion. Although feedbacks between hydrology, nutrients, and plant dominance may confound interpretations from field surveys, across 14 northern Great Lakes wetlands, Typha-dominated stands had greater SOM (14\% vs. $5 \%)$ and deeper surface organic horizons $(16 \mathrm{~cm}$ vs. $3 \mathrm{~cm})$ than uninvaded reference stands (Lishawa et al. 2010). Using a space-for-time substitution approach in a Lake Huron wetland complex, Mitchell et al. (2011) demonstrated that SOM content increased with time since Typha invasion.

Typha invasion alters $\mathrm{CH}_{4}$ emission from wetlands. A primary mechanism by which plants regulate $\mathrm{CH}_{4}$ emissions from wetlands is by providing the methanogen community with $\mathrm{C}$ substrates for anaerobic respiration (Sutton-Grier and Megonigal 2011). Biomass turnover and root exudation provide microbial communities with labile $\mathrm{C}$, with many studies observing greater $\mathrm{CH}_{4}$ emissions with greater Typha biomass production (Whiting and Chanton 1993; Updegraff et al. 2001; Cheng et al. 2007; Zhang et al. 2010; Kao-Kniffin et al. 2011). Similarly, 10 years after experimental Typha invasion, Lawrence et al. (2017) observed greater $\mathrm{CH}_{4}$ emissions from Typha-dominated vs. Carex/Schoenoplectus-dominated mesocosms, with aboveground biomass and soil $\mathrm{C}$ positively associated with $\mathrm{CH}_{4}$ emissions. In addition to providing abundant $\mathrm{C}$ substrates, spongy, aerenchymatous Typha tissues also provides a pathway for $\mathrm{CH}_{4}$ produced in the underlying anoxic sediment to bypass oxidized surface sediments and waters, thereby increasing $\mathrm{CH}_{4}$ emissions. McInerney and Helton (2016) observed greater $\mathrm{CH}_{4}$ emissions when Typha was present compared to unvegetated controls in constructed wetlands. Typha-mediated $\mathrm{CH}_{4}$ emissions accounted for $>50 \%$ of $\mathrm{CH}_{4}$ leaving the littoral zone of a dense Typha pond (Sebacher et al. 1985). Yavitt and Knapp (1995) and Yavitt and Knapp (1998) suggested that Typha acts as a capacitor, filling with $\mathrm{CH}_{4}$ at night and emitting during the day. This is supported by Windham-Myers et al. (2018), who observed 2-times greater $\mathrm{CH}_{4}$ emissions during the daytime than night in a Typha-dominated marsh.

Aerenchyma may also oxygenate the rhizosphere, potentially shifting microbial composition and activity and promoting $\mathrm{CH}_{4}$ oxidation that could reduce net emissions (Carmichael et al. 2014). This mechanism may be at least partially responsible for observations of negative (or no) relationships between biomass and $\mathrm{CH}_{4}$ emissions. Across nine wetland plant species, Kao-Kniffin et al. (2010) examined relationships among $\mathrm{CH}_{4}$ emission, biomass, and microbial communities and found that Typha had one of the lowest rates of emissions, and in general, $\mathrm{CH}_{4}$ emissions decreased with greater plant biomass. Within an impounded restored freshwater wetland in California, Windham-Myers et al. (2018) observed higher $\mathrm{CH}_{4}$ emissions from Typha-dominated vs. Schoenoplectus-dominated plots, despite Typha plots having lower aboveground-biomass. In a parallel study, He et al. (2015) observed lower acetoclastic methanogenesis activity via Methanosarcina in Typha rhizomes than Schoenoplectus. 
Kao-Kniffin et al. (2011) showed that an increase in $\mathrm{CH}_{4^{-}}$ producing archaea isolated from the rhizosphere of Typha was associated with enhanced plant biomass from $\mathrm{CO}_{2}$-stimulated roots, and that $\mathrm{CO}_{2}$-enrichment (700 ppm) elevated $\mathrm{CH}_{4}$ emissions (148\%).

\section{Agriculture}

The proliferation of Typha has impacted industrial-scale agriculture, small-scale production, and subsistence farming across the globe. Typha can affect a variety of agricultural sectors directly by competing with water-submerged crops such as wild rice, taro, and water chestnut (Muenscher 1955; Smith et al. 1977; Hawaii Invasive Species Council 2008; Minnesota Department of Natural Resources 2008; Pillsbury and McGuire 2009; Kumar 2011), or indirectly by altering sediment characteristics, salinity, plant communities, water quality, and water availability (Otis 1914; Glenn et al. 1995; Holm et al. 1997; Werner and Zedler 2002). However, Typha is not a major weed in large-scale production where herbicides, land preparation, and water management are used in integrated weed management plans (Mahajan et al. 2014).

Typha can act as a physical barrier to water flow and obstruct rivers, irrigation canals, farm ponds, reservoirs, and drainage ditches (Timmons et al. 1963; Hamdoun and El Tigani 1977; Kumar 2011; Rodenburg and Johnson 2013; Sabo et al. 2016). For example, after dam and canal installation in Nigeria, the expansion of $T$. domingensis caused river blockage that further reduced flooding, negatively affecting recession agriculture (Ringim et al. 2015). Additionally, impeded water flow combined with monotypic stands of Typha can interfere with fishing by obstructing travel and decreasing quality of fisheries (Morton 1975; Holm et al. 1997; Ringim et al. 2015). In India, about $40 \%$ of freshwater lakes are rendered unsuitable for pisciculture because of invasion by aquatic weeds, including Typha (Kumar 2011). Typha can also capture blowing snow in agricultural fields and result in the ponding of snow-melt water that can delay or prevent farmers from planting in these areas. To combat this effect, farmers will often burn Typha stands in the fall or early winter to remove standing vegetation (Renton et al. 2015).

Typha can also impact livestock forage, health, and pastureland. Typha provides low quality forage in terms of nutrient content and palatability (Timmons et al. 1963; Kirby et al. 2002). Although generally edible, a few cases have implicated Typha in poisoning horses (Kingsbury 1964), cattle (Hurst 1942), and humans (Woodcock 1925). Large stands of Typha can harbor increased disease vectors, such as mosquitoes, snails and parasitic worms, potentially putting livestock and humans at greater disease risk (Cantrell 1981; Cogels et al. 1997; Pfukenyi et al. 2005; Pope et al. 2005; Salako et al. 2016). In the case of traditional grazing in Nigeria, large swaths of Typha have reduced the amount of available dryseason pasture (Degeorges and Reilly 2006).

Typha-dominated wetlands provide habitat for wildlife species that impact agriculture. Typha has been found in feral hog diets and may help sustain hog populations when agricultural crops are not available (Bratton 1974; Herrero et al. 2004). Extensive swaths of Typha are roosting habitat for flocks of grain-eating birds. Weavers (Ploceidae) throughout Europe, Asia, and Africa impact rice (Oryza), wheat (Triticum), millet (Panicum), and sorghum (Sorghum) (Tanko 2007; Borokoni and Babalola 2012; Ringim et al. 2015). In South America, Dickcissels (Cardinalidae) feed on cereals such as rice and sorghum (Basili and Temple 1999). In North America, blackbirds (Icteridae) forage on sunflower (Helianthus) (Fig. 6i), corn (Zea), and rice (Meanley 1965; Dolbeer 1990; Glahn et al. 1994; Linz et al. 2011; Peer and Abernathy 2017). Interestingly, in California, limited area of fresh, green Typha growth has prompted the tricolored blackbird (Agelaius tricolor) to nest in agricultural fields, which requires producer buyouts or altered haying schedules to protect this endangered species (Meese 2006; Graves et al. 2013; Holyoak et al. 2014).

\section{Case Study: Typha, Blackbirds, and Crop Damage in the PPR}

Research on management of Typha-dominated wetlands and influences on wildlife and concurrent agricultural damage has mainly been carried out in the depressional wetlands of the PPR. Three blackbird species, red-winged blackbirds (Agelaius phoeniceus L.), common grackles (Quiscalus quiscula L.), and yellow-headed blackbirds (Xanthocephalus xanthocephalus Bonaparte) cause significant economic damage to crops, especially sunflower (Fig. 6i) and corn (Peer et al. 2003; Klosterman et al. 2013; Shwiff et al. 2017). Their combined post-breeding population, estimated at 75 million, prefers Typha-dominated semi-permanent wetlands as roost sites during late summer due to the increased protection provided by dense Typha stands (Peer et al. 2003). Flocks emanate from these safe havens to forage in nearby crops (Ralston et al. 2007), especially corn and sunflower (Klosterman et al. 2013). In 2009 and 2010, Klosterman et al. (2013) estimated that blackbirds annually damaged $\$ 1.3$ million USD and \$3.5 million USD of ripening corn and sunflower in North Dakota, respectively. Managing the areal coverage of Typha to reduce the availability of blackbird habitat is one method of dispersing large blackbird concentrations to many smaller roosts (Linz et al. 1995; Linz and Homan 2011), thereby reducing the severity of localized damage (Leitch et al. 1997) while improving wetland habitat (Linz 1992; Solberg and Higgins 1993; Linz and Homan 2011; Linz and Klug 2017).

Changing climate and hydrology may result in earlier and more robust spring growth of Typha, which then persists as 
live vegetation into autumn. Earlier-developing Typha would provide enhanced nesting habitat for blackbirds that are correspondingly arriving earlier on nesting grounds (Torti and Dunn 2005; Forcey and Thogmartin 2017). Dense Typha stands, combined with an adequate moisture regime, provide habitat for late-migrating blackbirds foraging on late-maturing crop varieties, especially sunflower and corn, which are supplanting small grains in the northern Great Plains (Klosterman et al. 2013). Harvested row crops, in combination with greater areal coverage of Typha within roost sites, could provide superior stopover habitats for blackbirds during both fall and spring migration in the US and Canada (Homan et al. 2006; Hagy et al. 2008; Galle et al. 2009). The relationships between climate change, hydrology, evolving wetland habitat, cold-tolerant crop varieties, blackbird migration, and Typha could well change crop damage distribution and intensity across agricultural areas of North America (Melillo et al. 2014; Forcey and Thogmartin 2017; Klug 2017).

\section{Section 4: Ecosystem Services}

\section{Customary and Traditional Uses}

Typha has long been important to indigenous peoples from various regions of the world, who have relied on each part of the plant for an assortment of uses ranging from food and medicine to production of goods (Morton 1975; Mitich 2000). Different portions of the plant are eaten raw or prepared in various ways (Fig. 8a), and flour made from Typha rhizomes has comparable protein content to corn, rice, and wheat. Typha can also be a source of feed and bedding material for livestock, albeit palatability is lower than other forage (Morton 1975; Mitich 2000; Ciria et al. 2005). Several cultures have developed medicinal applications for Typha ranging from treatment of burns, to use as an astringent, diuretic or wound wrapping, to a remedy for several afflictions. Plant parts have been used to produce goods such as woven baskets and mats, rope and twine, paper, sandals, fans, torches, spear handles, toys, and boats. In fact, harvesting $T$. domingensis for such goods may increase plant diversity in central Mexican wetlands (Hall et al. 2008). For some indigenous nations and communities, Typha remains an important food and medicinal plant and is regarded alongside other plants and animals as family or kin (Reo and Ogden 2018). In the LGL, Anishinaabe families continue to gather Typha for a wide variety of uses, primarily as a food item in the early spring (Fig. 8a). Reo and Ogden (2018) described a workshop in which elders taught youth how to harvest and prepare Typha. At this same workshop, participants successfully used the invasive $T$. $\times$ glauca to prepare traditional and new recipes as a way of enacting and discussing what Anishinaabe-Typha relations might look like in an era of invasive species.

Typha biomass also shows promise for use as building material and insulation and has shown potential for production of bio-adhesives (Morton 1975; Mitich 2000; Colbers et al. 2017). Typha 'seed fluff' has been used to stuff pillows, cushions, and mattresses, as kindling for lighting fires (Fig. 8b), and as fill for life-jackets during World War II (Morton 1975; Mitich 2000). More recently, Yu et al. (2017) suggested that porous $\mathrm{C}$ extracted from Typha could be used as an adsorbent and supercapacitor.

\section{Bioremediation}

Bioremediation is a soil and water management technique that uses biological organisms to break down and remove contaminants, including industrial, agricultural, and urban runoff (Gottschall et al. 2007; Pietro and Ivanoff 2015), wastewater (Vymazal 2013; Bhatia and Goyal 2014; Vymazal 2014), and mine waste (Groudev et al. 2008). Natural and constructed wetlands are widely used for various types of bioremediation, including phytoremediation (plants), microbial bioremediation (microorganisms), and mycoremediation (fungi) (Stottmeister et al. 2003; Marchand et al. 2010; Headley and Tanner 2012; Biswas 2015; Truu et al. 2015). Typha, in particular, has been associated with successful phytoremediation efforts, largely for metals and nutrients, due in large part to its rapid growth rates, capacity for elemental uptake, tolerance of contaminated environments, and limited translocation of
Fig. 8 Indigenous uses of Typha for a) cooking and $\mathbf{b}$ ) as part of a fire starter kit. Pictures taken at a workshop on Anishinaabe-Typha relationships (Reo and Ogden 2018)
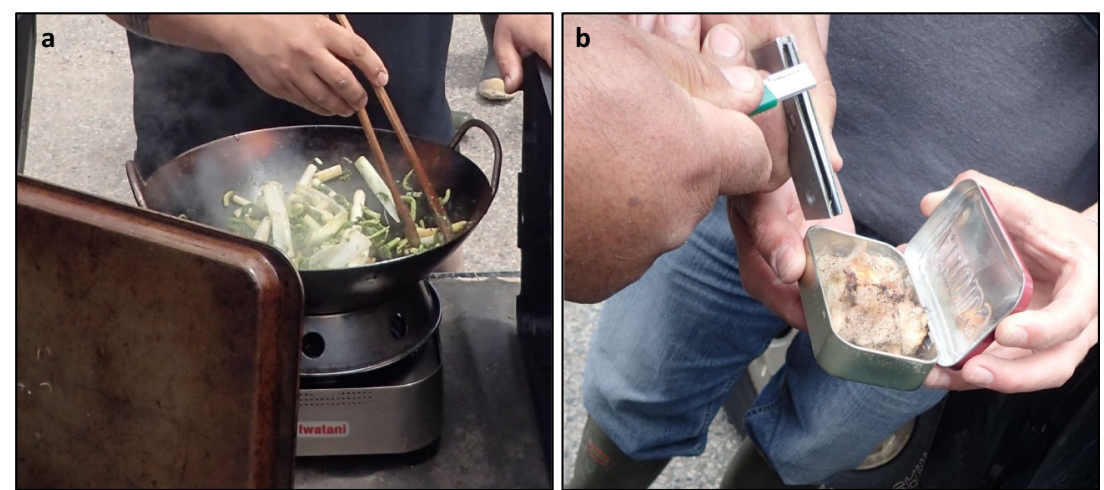
harmful elements from roots to aboveground biomass (Coon et al. 2000; Hegazy et al. 2011; Leto et al. 2013; Lyubenova et al. 2013; Gomes et al. 2014; Mufarrege et al. 2014; Pandey et al. 2014; Lominchar et al. 2015; Bonanno and Cirelli 2017).

In many parts of North America where Typha is considered invasive, nutrient removal (mainly $\mathrm{N}$ and $\mathrm{P}$ ) is important. The high biomass, growth rate, and clonal expansion rates of Typha result in stands of Typha acting as $\mathrm{N}$ and P sinks; thus, Typha stands may be useful for phytoremediation efforts (Coon et al. 2000; Woo and Zedler 2002; Gottschall et al. 2007; Gebremariam and Beutel 2008; Varnell et al. 2010; Grosshans et al. 2013; Chen and Vaughan 2014; Grosshans 2014; Grosshans et al. 2014; Jeke et al. 2015; Berry et al. 2017). Chen and Vaughan (2014), however, caution that prolonged inundation may affect the ability of Typha-dominated systems to remove P. In a six-years study of a Typhadominated wetland that served as a filter for a lotic system, Coon et al. (2000) reported that the wetland removed $28 \%$ of $\mathrm{P}$ inputs. Gottschall et al. (2007) reported that a Typha-dominated wetland removed up to $9 \%$ of total Kjeldahl N (sum of organic nitrogen, ammonia, and ammonium), $21 \%$ of ammonium, and 5\% of total P from livestock wastewater. Jeke et al. (2015) determined that harvesting of Typha biomass when aboveground nutrient concentrations are at their peak results in removal of $4 \%$ of total $\mathrm{N}$ and $3 \%$ of total $\mathrm{P}$ from municipal biosolids. Grosshans (2014) and Grosshans et al. (2013, 2014) evaluated harvesting of Typha biomass as a watershed remediation practice to reduce $\mathrm{P}$ loading to downstream Lake Winnipeg, resulting in 1-2 kg P per metric ton of biomass per year removed through harvested biomass in late summer. Gebremariam and Beutel (2008) showed that Typha was effective for treating nitrate-dominated wastewaters, with removal rates ranging up $400-500 \mathrm{mg} \mathrm{N} \mathrm{m}^{-2} \mathrm{~d}^{-1}$ when nitrate levels exceeded $15 \mathrm{mg} \mathrm{N} \mathrm{L}^{-1}$.

Many studies and reviews have indicated that various species of Typha show promise for phytoremediation of metals in wastewaters due to their ability to bioaccumulate metals such $\mathrm{Cd}, \mathrm{Cr}, \mathrm{Fe}, \mathrm{Hg}, \mathrm{Ni}, \mathrm{Pb}$, and $\mathrm{Zn}$ (Demirezen and Aksoy 2004; Maddison et al. 2009; Marchand et al. 2010; Hegazy et al. 2011; Mojiri et al. 2013; Bhatia and Goyal 2014; Sultana et al. 2014; Lominchar et al. 2015; Bonanno and Cirelli 2017). In a review of metal removal in constructed wetlands, Marchand et al. (2010) summarized removal rates for monocultures of Typha ranging from 48 to $99 \%$ for $\mathrm{Cd}, \mathrm{Cr}, \mathrm{Fe}, \mathrm{Ni}$, $\mathrm{Pb}$, and $\mathrm{Zn}$; moreover, Sultana et al. (2014) found $\mathrm{Cr}$ removal efficiency rates for Typha ranging from 50 to $95 \%$. Bhatia and Goyal (2014) reported that macrophytes including Typha accumulated 2049-6648 $\mu \mathrm{g}$ metal per gram of dry plant biomass and (Mojiri et al. 2013) reported that, under optimal conditions, $T$. domingensis removed $0.97,0.47$, and $0.37 \mathrm{mg} \mathrm{kg}^{-1}$ of $\mathrm{Pb}, \mathrm{Ni}$, and $\mathrm{Cd}$, respectively. Various studies also reported high $\mathrm{Hg}$ bioaccumulation factors for Typha (Gomes et al. 2014; Lominchar et al. 2015; Bonanno and Cirelli 2017). In addition, phytoabsorption by Typha has been suggested for treating de-icing salts in road ditches (Morteau et al. 2015).

\section{Bioremediation Case Study: South Florida Stormwater Treatment Areas}

In the 1990s, the State of Florida implemented a strategy to reduce total $\mathrm{P}$ loads from nutrient-rich stormwater runoff into the Everglades ecosystem by constructing bioremediation treatment wetlands, or Stormwater Treatment Areas (STAs) (Chimney and Goforth 2001). Currently, more than 23,000 ha have been converted to STAs where plants such as Typha uptake $\mathrm{P}$ (Chimney 2018). The $\mathrm{P}$ is stored in plant biomass and soils (as partially decomposed plant material), resulting in lower P loads transported downstream to the Everglades. In 2017 alone, it was estimated that STAs reduced total P loads and concentrations by nearly $85 \%$, preventing $>100$ metric tons of $\mathrm{P}$ from flowing into the Everglades (Chimney 2018). Furthermore, it has been estimated that over the 23 years since their establishment, the STAs have retained approximately 2300 metric tons of total $\mathrm{P}$ that otherwise would have been transferred to the Everglades (Chimney 2018).

Establishment of the STAs has provided ample opportunity for researchers to examine the effectiveness of treatment wetlands and wetland vegetation (e.g., Typha) for nutrient remediation in a subtropical region. Bhomia et al. (2015) and Pietro and Ivanoff (2015) examined soil and P accretion rates and P removal efficiency, while Chimney and Pietro (2006) and Dierberg and DeBusk (2008) assessed plant decomposition and particulate P. Other researchers have examined topics such as annual P loading, storage and removal, wetland restoration, mass balance models, and hydrology (e.g., Newman and Pietro 2001; Juston and DeBusk 2006, 2011; Moustafa et al. 2011; Juston et al. 2013; Chen et al. 2015). Chimney and Pietro (2006) reported low decomposition rates for Typha compared to other plant species, suggesting that Typha-dominated wetlands would be ideal for retaining P; however, various species of submerged aquatic vegetation may remove greater amounts of soluble P than Typha. To date, research from the south Florida STAs and elsewhere (see references in Kadlec and Wallace 2009) indicates that wetlands and their associated plant communities, including Typha, can be effective at bioremediation.

\section{Biomass Harvest}

Management of Typha often includes removal of biomass (Fig. 9d), and recent research and reviews have examined the potential use of this biomass as a biofuel crop (Dubbe et al. 1988; Ciria et al. 2005; Wang et al. 2011; Grosshans et al. 2013; Grosshans 2014; Grosshans et al. 2014; Elhaak et al. 2015; Rahman et al. 2015; Svedarsky et al. 2016; Ahmad 


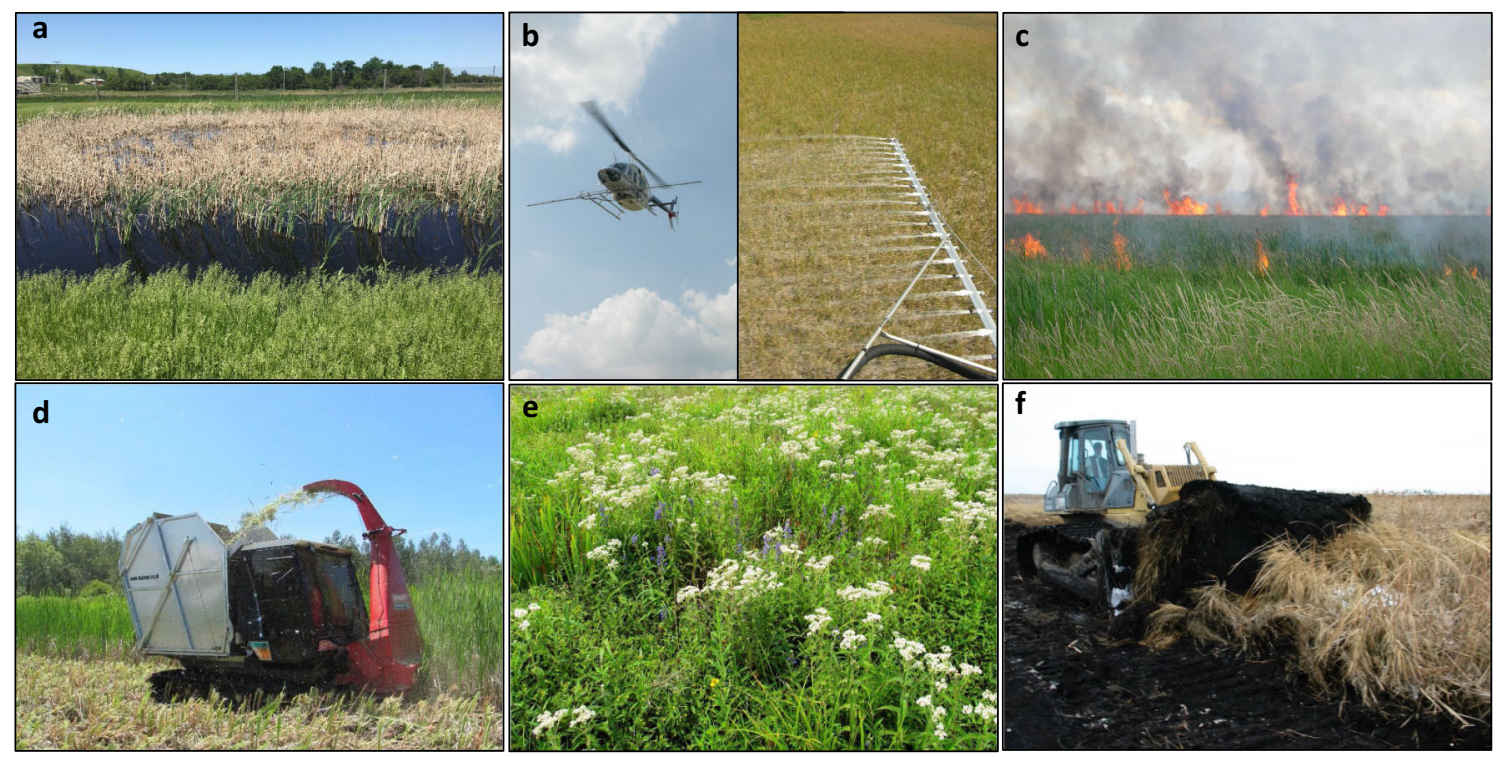

Fig. 9 Various examples of Typha management techniques: a water-level manipulation at an experimental wetland at the U.S. Geological Survey, Northern Prairie Wildlife Research Center in the Prairie Pothole Regionnote that flooding killed most of the Typha in the wetland, but some rhizomes near the wetland edge were able to send up new ramets that require additional treatments; $\mathbf{b}$ aerial application of herbicide to manage Typha within the northern Everglades; $\mathbf{c}$ prescribed burn of a Typha marsh at Agassiz National Wildlife Refuge, Minnesota, USA in 2006 where flame heights reached $>9 \mathrm{~m}$; d harvesting Typha $\times$ glauca with a biomass harvester designed for wetland use (Loglogic Softrak, Devon England, U.K.) in Cheboygan Marsh, Michigan, USA; e re-vegetation to restore floristic diversity at Cowles Bog Wetland Complex in Indiana Dunes National Lakeshore; and f) removal of Typha biomass and sediment to restore wetland habitat in the Prairie Pothole Region et al. 2017; Berry et al. 2017; Rebaque et al. 2017; Carson et al. 2018). In a review of Typha management in the northern Great Plains, Svedarsky et al. (2016) highlighted numerous advantages that Typha has over other sources of biomass, including that it occurs in wetland areas that are not suitable for conventional agriculture, it is quickly renewable, it is a Cneutral resource, tillage and replanting are typically not required, and harvesting Typha can improve wetland habitats. Rahman et al. (2015) demonstrated that byproducts of fresh Typha biomass can be used directly in the production of ethanol, as well as indirectly through the cultivation of microalgae that can then be used to produce ethanol. Moreover, Berry et al. (2017) suggested that, in addition to providing a biofuel feedstock and reducing downstream nutrient loading, harvesting of plant (e.g., Typha) biomass from surface-water retention systems provided additional income for landowners through various revenue streams.

A number of studies have examined the thermal characteristics of Typha, and identified optimal processing methods for ethanol production. Studies show T. latifolia holds great promise as a bioenergy feedstock due to its structural cellwall polysaccharides (Rebaque et al. 2017), high yields, thermal properties (Ciria et al. 2005), and favorable kinetic and thermodynamic properties (Ahmad et al. 2017). In a study examining $T$. latifolia as a potential biofuel alternative to petroleum, Aysu et al. (2012) determined conversion percentages from supercritical gas extraction that ranged from roughly $55-70 \%$, values comparable to other plants such as
Phalaris arundinacea (reed canarygrass) (52-73\%) and Arundo donax (giant reed) (40-82\%) (Aysu 2012; Aysu and Küçük 2013). Carson et al. (2018) quantified Typha's potential as a feedstock for biogas production in anaerobic digesters and determined that untreated Typha was a suitable material for use in mixed source biomass digesters.

A comprehensive study was conducted at Netley-Libau Marsh at Lake Winnipeg, Canada, to assess the feasibility of annual biomass (including Typha) harvesting for nutrient bioremediation and biofuel production (Cicek et al. 2006; Grosshans 2014). Annual biomass harvesting would result in the removal of $\sim 1.0-1.4 \mathrm{kt}$ of total $\mathrm{N}$ and 188-227 tons of total $\mathrm{P}$ from inflows from the Red River, which enter Lake Winnipeg through Netley-Libau Marsh (Cicek et al. 2006). Cicek et al. (2006) also examined the efficacy of various bioenergy production technologies and concluded that they could produce 1.754.71 MW of power, in addition to the added benefit of usable, cogenerated heat. Grosshans (2014) estimated that harvesting Typha biomass resulted in 15-20 tons dry mass $\mathrm{ha}^{-1}$, effectively removing 30-60 $\mathrm{kg} \mathrm{P} \mathrm{ha}{ }^{-1}$ year ${ }^{-1}$. Moreover, compressed Typha fuel pellets produced heat similar to commercial wood pellets, with values ranging from 16-20 $\mathrm{MJ} \mathrm{kg}^{-1}$ (Grosshans et al. 2013; Grosshans 2014; Grosshans et al. 2014; Carson et al. 2018). Grosshans (2014) noted that further exploration of economic factors is required to assess feasibility of biomass harvest for nutrient removal and biofuel feedstock, and 
that harvesting Typha for multiple uses (e.g., nutrient capture, bioenergy, habitat management, $\mathrm{C}$ offsets, biochar) likely would be required to make the process economically viable. Grosshans et al. (2013, 2014) subsequently implemented Typha harvesting at an applied scale in a managed wetland utilized for water retention in the Lake Winnipeg Watershed in Manitoba, Canada. This work demonstrated that managed Typha wetlands utilized for water retention provide a suite of stacked benefits in addition to flood water storage: reduced nutrient loading, enhanced wildlife habitat and biodiversity, and sustainable biomass for renewable energy and bioproducts. The 500ha Pelly's Lake engineered wetland provides 148 ha-m of controlled water storage and has removed over 5 metric tons of $\mathrm{P}$ through Typha harvest management.

\section{Section 5: Management and Restoration}

\author{
"In theory, there is no difference between theory and \\ practice. But in practice, there is." \\ -Yogi Berra
}

Control of Typha has long been a wetland management concern. Early approaches involved herbicide treatments and water-level manipulations (Steenis et al. 1959; Harris and Marshall 1963). Later, studies tested hand-cutting, mowing, crushing, cultivation, scraping, herbicides, explosives, fire, altering salinity levels, flooding, and drought (Nelson and Dietz 1966; Linde et al. 1976; Beule 1979). On-going studies continue testing various treatments to control Typha (Mallik and Wein 1986; Comes and Kelley 1989; Kostecke et al. 2004; Asamoah and Bork 2010; Linz and Homan 2011; Rodgers and Black 2012; Hagerthey et al. 2014). Controlling Typha with mechanical or chemical methods alone is rarely successful because of the large rhizome system that allows Typha to regenerate quickly ( $\mathrm{Tu}$ et al. 2001; Svedarsky et al. 2016). Regardless of management technique employed, multiple actions are typically needed to control Typha, and hydrology and timing relative to Typha's life history should be considered (Linde et al. 1976; Beule 1979; Gleason et al. 2012; Wilcox et al. 2018). Moreover, the effects of successful treatments often are short-lived, and active management and repeated treatments likely will be required. The goal of this section is to provide a general overview of various management techniques; existing reviews on Typha management provide considerably more detail on control strategies, including Apfelbaum (1985), Sojda and Solberg (1993), and more recently, Svedarsky et al. (2016).

\section{Water-Level Manipulation}

Aquatic plants vary in their response to water depth, and it has been suggested that Typha vigor can be inhibited when water depth exceeds tolerable levels of $1 \mathrm{~m}$ (Linde et al. 1976; Beule 1979; Grace and Wetzel 1982a; Grace 1989; Waters and Shay 1990; Sojda and Solberg 1993; van der Valk 1994; Chen et al. 2010) (Fig. 9a). Typha also has been shown to be sensitive to drought (Nelson and Dietz 1966; van der Valk and Davis 1980; Li et al. 2004; Asamoah and Bork 2010). Consequently, water-level manipulation has the potential to control Typha via flooding or desiccating substrates. However, water-level manipulations, both draining and flooding, appear to be most effective when coupled with other management techniques such as burning or cutting (e.g., Nelson and Dietz 1966; Mallik and Wein 1986; Ball 1990). In wetlands with organic soils, extensive draining causes an increase in inorganic nutrients, as well as increased fire risk, potentially thus exacerbating Typha invasion (Newman et al. 1998; Smith et al. 2003).

\section{Herbicide Management}

Herbicides used to chemically control Typha include 2,4dichlorophenoxyacetic acid (2,4-D) (Steenis et al. 1959; Corns and Gupta 1971), glyphosate (Schimming et al. 1987; Messersmith et al. 1992; Solberg and Higgins 1993; Linz and Homan 2011), imazapyr (Foloni and Pitelli 2005), and imazamox (Rodgers and Black 2012). Each of these herbicides has commercially available formulations labeled by the US Environmental Protection Agency for aquatic use. All these herbicides are classified as systemic (absorbed and translocated throughout the plant) and are considered nonselective (kill or damage all plants), although selective control has been reported for imazamox applied at low rates (Rodgers and Black 2012). Applications of these herbicides are typically carried out as foliar treatments by ground applicators using tank sprayers, but large treatments can be performed using aircraft (Sojda and Solberg 1993; Thompson et al. 2010; Linz and Homan 2011; Newman et al. 2017) (Fig. 9b) or smaller, more targeted treatments can be applied by handwicking stems (Wilcox et al. 2018). Herbicide treatment efficacy is reportedly season-dependent, with the most effective control achieved in late summer months when Typha are actively growing and transporting carbohydrates to their rhizomes (Linz and Homan 2011).

Excess nutrients are one of the key drivers of Typha invasion (Woo and Zedler 2002; Larkin et al. 2012b), and increasing nutrient availability creates conditions more suitable for re-invasion. Hagerthey et al. (2014) found that total P in the flocculant and soil layers were elevated in herbicide-treated and burned Everglades Typha marshes compared to untreated controls. Similar findings of increased pore-water and plant- 
available $\mathrm{N}$ and $\mathrm{P}$ were observed in wetlands that were glyphosate-treated to control T. $\times$ glauca (Lawrence et al. 2016b). Thus, application of herbicide may provide shortterm control of Typha but ultimately create conditions for more aggressive re-invasion.

Development of herbicide resistance in Typha has the potential to occur, particularly when using reduced herbicide application rates (Neve and Powles 2005). Restoration practitioners utilizing this approach should include an herbicide resistance management program in their management plan (Norsworthy et al. 2012). Zheng et al. (2017) found absorption of the herbicide glyphosate is four-times greater for native T. latifolia than $T . \times$ glauca, suggesting herbicide application could be causing resistance in the hybrid $T . \times$ glauca, and could ultimately aid the spread of the more glyphosateresistant hybrid while eliminating native species.

\section{Burning}

Prescribed fire is a broadly used technique for controlling invasive plants such as Typha (Beule 1979; Sojda and Solberg 1993; Ponzio et al. 2004; Gleason et al. 2012; Svedarsky et al. 2016) (Fig. 9c). Studies have shown that T. $\times$ glauca cover can be reduced immediately after burns, but can recover rapidly due to limited belowground effects of fire (Smith and Kadlec 1985; Gleason et al. 2012). In contrast, fire has been shown to favor $T$. domingensis by creating openings in the landscape and increasing bioavailable $\mathrm{P}$ (Smith and Newman 2001); fire can temporarily increase T. domingensis dominance over native species for 1-2 years post-fire (Ponzio et al. 2004). Therefore, the efficacy of fire for controlling Typha is highly variable, and results are often best when combined with other management techniques (e.g., Mallik and Wein 1986; Kostecke et al. 2004). A critical factor for implementing fires in wetland systems is the ability to manipulate water levels; if a site cannot be sufficiently dried, the probability of an effective fire is reduced (Gleason et al. 2012). Fire also eliminates the dense litter layer, which can facilitate re-establishment by native species but also reinvasion by Typha.

\section{Physical Disturbance}

Physical disturbances such as grazing, mowing, disking, shearing, crushing, and scraping are commonly used to control Typha (Beule 1979; Murkin and Ward 1980; Schultz 1987; Ball 1990; Sojda and Solberg 1993; Payne 1998; Wilcox et al. 2018). Weed-cutting boats (Hellsten et al. 1999), fangueo aquatic tractors (Osland et al. 2011), aquatic weed-wackers (Lishawa et al. 2015), conventional agriculture equipment including haybines and rotary disc mowers (Grosshans et al. 2013; Grosshans et al. 2014; Svedarsky et al. 2016) and a tracked biomass harvester (Lishawa et al.
2017) (Fig. 9d) have been used to remove Typha or reduce its biomass. In the PPR, Smith et al. (2016) found that physical removal of Typha and the underlying sediment from wetlands resulted in plant communities that were closer in composition and structure to uninvaded reference wetlands. Reducing aboveground biomass by cutting and then flooding was shown to be effective by reducing $\mathrm{O}_{2}$ transport to the rhizomes and limiting future growth (Weller 1975; Sale and Wetzel 1983; Jordan and Whigham 1988; Ball 1990). Likewise, cutting Typha below water and removing its biomass results in high levels of Typha mortality (Berke 2017; Lishawa et al. 2017). Where flooding is not possible, cutting Typha ramets when stored carbohydrates in the rhizomes are at their lowest concentrations reduces survival (Sojda and Solberg 1993). Multiple cuts may be necessary to draw down robust rhizome carbohydrate reserves; Hall and Zedler (2010) found that four cutting treatments in one season were necessary to reduce $T$. $\times$ glauca rhizome starch concentrations below reference levels in a nutrient-enriched urban wetland. Additionally, repeat and follow-up treatments such as herbicide application are often needed to reduce new growth from re-sprouting (Wilcox et al. 2018).

\section{Biomass Harvest}

Harvesting Typha biomass and its litter for bioenergy production consistently increases native biodiversity and habitat complexity over the short-term under a range of environmental conditions. In a heavily invaded Lake Huron coastal wetland, aboveground harvest under dry and flooded conditions in summer resulted in a doubling of native plant species richness and diversity for at least 2 years following treatment (Lishawa et al. 2015; Berke 2017). Lishawa et al. (2017) found that harvesting Typha biomass above water appears to be more effective for restoring native emergent plant dominance in younger Typha stands, while cutting below water significantly increases subm ergent plant diversity. Harvesting T. domingensis biomass in central Mexico increased native species richness and Shannon diversity (Hall et al. 2008). While harvesting alone does not always eliminate Typha, it consistently increases native plant diversity; however, repeated harvests are likely needed to alter environmental conditions in invaded stands. Five years after a one-time aboveground Typha harvest, no differences were detected between harvested and unmanipulated Typha-dominated reference plots in terms of microbial community composition, $\mathrm{CO}_{2}$ flux, or porewater nutrient concentrations, despite an increase in the relative dominance of native species (Keyport et al. 2019). This suggests that the legacy effects of Typha invasion on sediment parameters may be more persistent than those on plant community composition. 


\section{Herbivory and Grazing}

Herbivores such as muskrats, cattle, goats, and geese will feed on Typha seedlings, as well as roots, stems, and leaves of mature plants (Takos 1947; Bellrose 1950; Smith 1988; Lacki et al. 1990; Nelson et al. 1990a; Sojda and Solberg 1993; Campbell and MacArthur 1994; Silliman et al. 2014). The grass carp (Ctenopharyngodon idella) has even been identified as a potential control agent for Typha (Carney and deNoyelles 1986), although many states prohibit its introduction. Muskrats also favor Typha for use in constructing lodges (Bellrose and Brown 1941; Danell 1979; Clark 1994). Although research and observation indicate that muskrats may decrease Typha biomass (Sojda and Solberg 1993; Connors et al. 2000; Farrell et al. 2010), formal research assessing the potential of muskrats to control extensive Typha stands is limited. Silliman et al. (2014) demonstrated that grazing by goats or other livestock can be an effective method for controlling $P$. australis, suggesting that it may also be a viable control option for Typha. Sojda and Solberg (1993) suggested that grazing-associated mortality of mature plants is rare, especially for those with extensive rhizomes, but that grazing could be effective in controlling seedlings. Also, reducing Typha litter biomass using invertebrate litter consumers, such as shrimp (Kong et al. 2019), may improve growth of native plants. As with other treatments, effects of grazing likely would be maximal when combined with other treatments (e.g., water-level manipulation), and implementation should consider the life history of Typha (Sojda and Solberg 1993).

\section{Re-Vegetation}

Plant community composition following Typha removal is dependent on the composition of the remnant seed bank, incoming propagules, and environmental conditions (e.g., nutrient regime). Studies have shown that seed banks play an important role in wetland vegetation dynamics and that seed banks and plant species composition of disturbed wetlands can be quite different than those of natural wetlands (van der Valk and Davis 1978; Galatowitsch and van der Valk 1996; Gleason et al. 2003). Therefore, the addition of competitive herbaceous species by planting plugs and/or seeding may be needed to supplement natural recovery of native plant species (Smith et al. 2002; van der Valk and Baalman 2018) (Fig. 9e). Soil transplantation also has shown promise as a technique for establishing desired wetland vegetation while inhibiting the spread of Typha (Brown and Bedford 1997). In terms of assessing the success of restoration or re-vegetation efforts, prolonged studies are required since vegetation succession trajectories often do not follow long-term expectations, and hydrologic conditions of wetlands can vary significantly over time (Zedler 2000; Euliss et al. 2004; Aronson and
Galatowitsch 2008; Matthews et al. 2009; Matthews and Spyreas 2010).

\section{Nutrient Management}

Typha response to nutrient enrichment is stronger than that of many competing species (Newman et al. 1996; Woo and Zedler 2002), suggesting that Typha management could be more effective if combined with nutrient reductions (i.e., treating an underlying cause of Typha dominance). In a modeling study, Elgersma et al. (2017) found that reducing nutrient inputs was more effective at limiting Typha growth compared to herbicide, fire, or mowing in the absence of nutrient reductions. A small-scale experimental study using $\mathrm{C}$ additions to sequester $\mathrm{N}$ demonstrated that reductions in nutrient availability can reduce the competitive ability of a nitrophilic wetland invader (Perry et al. 2004), but largescale application of this approach is logistically challenging, especially in wetlands. When restoring degraded or former cropland wetlands, methods also include excavation of accumulated sediments and associated biomass such as Typha rhizomes that will also remove nutrients from the wetland (Smith et al. 2016) (Fig. 9f). Watershed-scale nutrient reduction efforts are extremely challenging to implement, especially given the predominance of nonpoint sources of nutrients in agricultural areas where Typha invades, such as the LGL, Lake Winnipeg watershed, Everglades, and PPR (Luscz et al. 2015). Observed declines in Typha expansion during a period of reduced external nutrient loading in the Everglades (Rutchey et al. 2008) provides some evidence that nutrient reductions may indirectly benefit management efforts. Recent large-scale studies indicate that external nutrient-load reductions, combined with active Typha management, can result in the establishment of more desirable emergent and submerged species, which in turn can reduce nutrient accumulation (Newman et al. 2018) and potentially Typha regrowth.

\section{Management Trade-Offs}

Ultimately, managing Typha involves trade-offs. While cutting followed by flooding or cutting below water is highly effective at killing Typha (Weller 1975; Sale and Wetzel 1983; Jordan and Whigham 1988; Ball 1990), this approach results in high levels of mortality to native emergent species as well (Lishawa et al. 2017). Amphibians and other gillbreathing organisms are also at risk from aggressive and high frequency nature of Typha control, particularly during early spring and summer when larvae are present and metamorphosing, although there is still considerable uncertainty regarding these impacts (Krynak et al. 2017).

In the Everglades, initial active Typha management efforts using aerially applied glyphosate and imazapyr shifted a Typha marsh to an open water habitat dominated by 
periphyton and submersed aquatic-vegetation, but it also removed remnant macrophytic vegetation typical of Everglades marsh communities (Hagerthey et al. 2014). However, the use of herbicide for selective Typha control may provide opportunities to limit mortality to remnant native-plant communities targeted for restoration and may present a viable management option when mechanical removal techniques are impractical. Rodgers and Black (2012) found that aerial applications of imazamox at moderate doses effectively controlled Typha for 1 year in Everglades marsh plant communities, with little to no mortality of other native plant species. By contrast, aerial imazamox applications in highly nutrient enriched areas with greater Typha densities resulted in moderate Typha control and required follow up treatments to sustain control (Newman et al. 2017; Newman et al. 2018). However, regular use of herbicides may also lead to herbicide resistance and spread of more resistant hybrids (Zheng et al. 2017). Thus, additional research on selective control of Typha is needed to determine species-level differences among Typha congeners and the tolerance of other wetland species to lower imazamox application rates in order to minimize frequency and rates of application.

Integrated Typha management strategies, which emphasize a holistic approach by utilizing combinations of control methods, may improve Typha management outcomes while reducing the reliance on herbicides (Buhler 2002; Buckley et al. 2004). Which combinations and sequencing of management tools will be most effective is likely dependent on the species of Typha, environmental conditions, management objectives, and scale of management operation.

\section{Section 6: Future Research Needs}

Despite the abundance of research articles on Typha, there are still major research gaps that need to be addressed. Here we identify several essential topics for future research.

\section{Distribution}

Niche modeling approaches are needed to better predict future distributions of all Typha taxa under scenarios of global change, as there have been few studies on climatic limitations of Typha. Scenarios to be explored through modeling should focus on the role of warmer temperatures and changes in timing of seasonal temperature shifts, magnitude of annual and diurnal temperature ranges, and frequency of extreme temperature maxima or minima. Modeling efforts should also include exploring the effects of altered hydrological regimes, other human impacts, including eutrophication and road salt inputs (Hood 2013), competing invasive species (e.g., P. australis), and the direct effects of higher $\mathrm{CO}_{2}$ on Typha distributions.
To validate resulting models, paleoecological records extending through Pleistocene interglacials and pre-Quaternary intervals, particularly those that experienced warmer temperatures than the Holocene and are potential analogs for future warmer worlds (Fischer et al. 2018), are needed. These will inform constraints on future distributions of $T$. angustifolia and other Typha species. Typha pollen and macrofossils are documented in paleobotanical records at least as old as the early Miocene (23 million years ago) (Lee et al. 2012), suggesting that the fossil record can be further exploited to understand the responses of Typha to global change.

\section{Genetics}

Future work is urgently needed on the potential contributions of non-native lineages to regional patterns of invasion by Typha in North America. Recent work by Travis and Marburger (unpublished data) using microsatellite markers indicated the possibility of introgression of T. angustifolia alleles into northern Everglades Typha populations, in spite of the apparent absence of pure T. angustifolia in the region. This observation is explainable through linkage of microsatellite markers to $T$. angustifolia genes under positive selection, whose spread well ahead of the actual hybridization front could have been facilitated through a pattern of repeated backcrossing to increasingly southern populations of either $T$. domingensis or T. latifolia. Note, however, that firm conclusions in this regard await a more thorough characterization of $T$. domingensis alleles, which may partially overlap with those of $T$. angustifolia.

Additionally, evidence for tri-hybrid crosses among the three Typha species needs further exploration. Development of more nuclear and cytoplasmic markers, as well as whole genome sequencing, could clarify genetic relationships of the species and hybrids, while seed bank/pollen studies across North America would show the regional variation and persistence of hybrids over longer periods of time.

\section{Ecological Impacts}

The majority of research on the ecological impacts of invasive Typha has focused on changes in plant and avian communities. However, Typha invasion impacts all wetland trophic levels, and more research on the impacts of Typha on fishes, invertebrates, amphibians, and pollinators is needed. Studies should examine the potential impacts of Typha invasion on wetland food webs, as well as on the makeup and structure of wetland biotic communities (e.g., aquatic invertebrates, amphibians). In the PPR, research related to pollinator habitats, including wetlands, has been identified as nationally important. Focal areas for research should include impacted areas such as the LGL, Florida Everglades, and PPR, along with areas that are likely to be impacted. 


\section{Biogeochemistry}

Soils in Typha-dominated wetlands tend to have greater rates of denitrification, as well as $\mathrm{N}$ mineralization. However, to the best of our knowledge, a comprehensive N-budget that directly compares these elevated rates of $\mathrm{N}$ mineralization against increased denitrification rates is not yet available. A related question with management implications is how to reverse the positive feedback between nutrient availability and Typha species invasions. Further, experimental investigation of how Typha invasion alters rhizospheric-microbial relationships and $\mathrm{CH}_{4}$ emissions is necessary to better understand the role of Typha invasions on wetland C balance.

\section{Management}

The initial question regarding Typha management relates to the decision on when it is necessary. Some obvious cases for management are in natural areas where native vegetation has been displaced by Typha invasion, mostly by $T$. angustifolia and T. × glauca (e.g., Wilcox 1986; Wilcox et al. 2008) or when the native Typha species, e.g., T. domingensis has created a monoculture due to anthropogenic disturbance (Newman et al. 1998; Smith and Newman 2001). However, in other cases, especially when T. latifolia is the Typha species present, photointerpretation studies may be needed making use of historical imagery to determine if invasion is ongoing. Models constructed in a GIS environment may be developed to predict future changes in Typha invasion and need for management, such as when changes will be made in water-level management (e.g., Wilcox and Xie 2007). There is also a very real need for information on when it is necessary to repeat management. The effects of Typha management are often temporary, but the extent to which this is the case is often hard to know because of the lack of long-term monitoring in most restoration projects.

An interdisciplinary, systems approach is needed for Typha management, especially for $T$. × glauca; ideally Typha-choked wetland basins could be partially harvested to achieve a spectrum of uses, including enhanced wildlife habitat, nutrient bioremediation, biofuel production, bioproduct generation (e.g., construction materials), stimulation of local economies, and climate change mitigation. Simultaneous research is needed to identify the appropriate combination of biological, engineering, and economic conditions of various sites needed to achieve project feasibility. A major outstanding question is why $T . \times$ glauca is so problematic from a management perspective in so many places, whereas T. latifolia is present in these regions but is generally not a management concern. Little is known about the role herbivores and pathogens play in limiting growth of different Typha taxa, and whether 'enemy escape' plays a role in Typha invasions. Better understanding these questions using basic ecological research will promote systems-based management approaches. A complementary approach might include an economic Input-Output model integrating the costs and benefits of Typha management in relation to biomass harvest and agriculture damage (Shwiff et al. 2017). Finally, there is great potential to improve management and stewardship responses to Typha invasions through collaboration with indigenous peoples to integrate customary and traditional uses of Typha by local communities.

Despite frequent mention of integrated pest management (IPM) as a cost-effective, environmentally-sound approach to invasive plant management, there is little research involving Typha and IPM (but see Mallik and Wein 1986; Kostecke et al. 2004; Wilcox et al. 2018). More research is needed to determine optimal combinations and sequencing of control tools for Typha, particularly in systems where Typha is often difficult to control. For example, sustained control of $T$. domingensis is challenging in nutrient-enriched Everglades marshes using herbicides or fire alone (Newman et al. 2018). In addition, tradeoffs between Typha management and downstream impacts of Typha management, e.g., translocation of nutrients to unenriched areas, require further investigation. Field studies evaluating different control tool combinations may reveal sustainable management strategies. However, it is important to note that IPM strategies are likely to be highly influenced by scale, as well as species- and region-dependent given documented variation in management outcomes. Therefore, studies should encompass a broad range of habitats such as the LGL, Florida Everglades, and PPR, be conducted at appropriate scales to inform management (e.g., management unit, wetland complex), and be of adequate length to assess long-term outcomes.

Acknowledgments This research was funded in part by the U.S. Geological Survey Land Resources Mission Area, Land Change Science Research and Development Program. We sincerely thank the many scientists who have contributed to our understanding of Typha through decades of dedicated research on this genus. We thank Jacob Meier and Olivia Johnson for assistance with figures, Lowell Washburn and Craig Bihrle for deer and pike photos, and Isa Woo and Gregg Knutsen for reviewing our manuscript.

Open Access This article is distributed under the terms of the Creative Commons Attribution 4.0 International License (http:// creativecommons.org/licenses/by/4.0/), which permits unrestricted use, distribution, and reproduction in any medium, provided you give appropriate credit to the original author(s) and the source, provide a link to the Creative Commons license, and indicate if changes were made.

\section{References}

Abbott RJ (1992) Plant invasions, interspecific hybridization and the evolution of new plant taxa. Trends in Ecology \& Evolution 7:401-405

Ahee JE, Van Drunen WE, Dorken ME (2015) Analysis of pollination neighbourhood size using spatial analysis of pollen and seed production in broadleaf cattail (Typha latifolia). Botany 93:91-100 
Ahmad MS, Mehmooda MA, Taqvi STH, Elkamel A, Liu CG, Xu JR, Rahimuddin SA, Gull M (2017) Pyrolysis, kinetics analysis, thermodynamics parameters and reaction mechanism of Typha latifolia to evaluate its bioenergy potential. Bioresource Technology 245: 491-501

Albert DA, Brown PW (2008) Analysis of vegetation in adjacent dikedundiked coastal wetlands. Available via MNFI https://mnfi.anr.msu. edu/reports/2008-14\%20Diked\%20Wetland\%20Rpt\%20-\%20Ecol. pdf. Accessed 1 Sept 2018

Albert DA, Wilcox DA, Ingram JW, Thompson TA (2005) Hydrogeomorphic classification for Great Lakes coastal wetlands. Journal of Great Lakes Research 31:129-146

Allen P, Kleinmann RLP (1991) The use of constructed wetlands in the treatment of acid mine drainage. Natural Resources Forum 15:178184

Anderson CJ, Mitsch WJ (2006) Sediment, carbon, and nutrient accumulation at two 10-year-old created riverine marshes. Wetlands 26: 779-792

Andrews NJ, Pratt DC (1978) Energy potential of cattails (Typha spp.) and productivity in managed stands. Journal of the Minnesota Academy of Science 44

Angeloni NL, Jankowski KJ, Tuchman NC, Kelly JJ (2006) Effects of an invasive cattail species (Typha $\times$ glauca) on sediment nitrogen and microbial community composition in a freshwater wetland. FEMS Microbiology Letters 263:86-92

Anteau MJ (2012) Do interactions of land use and climate affect productivity of waterbirds and prairie-pothole wetlands? Wetlands 32:1-9

Anteau MJ, Afton AD, Anteau ACE, Moser EB (2011) Fish and land use influence Gammarus lacustris and Hyalella azteca (Amphipoda) densities in large wetlands across the upper Midwest. Hydrobiologia 664:69-80

Anteau MJ, Wiltermuth MT, van der Burg MP, Pearse AT (2016) Prerequisites for understanding climate-change impacts on northern prairie wetlands. Wetlands 36:299-307

Apfelbaum SI (1985) Cattail (Typha spp.) management. Natural Areas Journal 5:9-17

Armstrong W (1979) Aeration in higher plants. Advances in Botanical Research 7:226-332

Armstrong J, Armstrong W, Beckett PM (1992) Phragmites australis: Venturi- and humidity-induced pressure flows enhance rhizome aeration and rhizosphere oxidation. New Phytologist 120:197-207

Arnold ML (1997) Natural hybridization and evolution. Oxford University Press, New York

Aronson MFJ, Galatowitsch S (2008) Long-term vegetation development of restored prairie pothole wetlands. Wetlands 28:883-895

Asaeda T, Sharma P, Rajapakse L (2008) Seasonal patterns of carbohydrate translocation and synthesis of structural carbon components in Typha angustifolia. Hydrobiologia 607:87-101

Asamoah SA, Bork EW (2010) Drought tolerance thresholds in cattail (Typha latifolia): a test using controlled hydrologic treatments. Wetlands 30:99-110

Aysu T (2012) Supercritical fluid extraction of reed canary grass (Phalaris arundinacea). Biomass and Bioenergy 41:139-144

Aysu T, Küçük MM (2013) Liquefaction of giant reed (Arundo donax L.) by supercritical fluid extraction. Fuel 103:758-763

Aysu T, Turhan M, Küçük MM (2012) Liquefaction of Typha latifolia by supercritical fluid extraction. Bioresource Technology 107:464-470

Badiou P, McDougal R, Pennock D, Clark B (2011) Greenhouse gas emissions and carbon sequestration potential in restored wetlands of the Canadian prairie pothole region. Wetlands Ecology and Management 19:237-256

Baldwin B, Cannon A (2007) Typha review. Available via UMT http:// files.cfc.umt.edu/cesu/NPS/USU/2006/06Baldwin GRKO Typha\%20review_frpt.pdf. Accessed 1 Sept 2018
Ball JP (1990) Influence of subsequent flooding depth on Typha control by burning and mowing. Journal of Aquatic Plant Management 28: $32-36$

Ball D, Freeland JR (2013) Synchronous flowering times and asymmetrical hybridization in Typha latifolia and T. angustifolia in northeastern North America. Aquatic Botany 104:224-227

Basili GD, Temple SA (1999) Winter ecology, behavior, and conservation needs of Dickcissels in Venezuela. Studies in Avian Biology 19: 289-299

Batzer DP (2013) The seemingly intractable ecological responses of invertebrates in north American wetlands: a review. Wetlands 33:1-15

Beare PA, Zedler JB (1987) Cattail invasion and persistence in a coastal salt marsh: the role of salinity reduction. Estuaries 10:165-170

Bedish JW (1964) Studies of the germination and growth of cattail in relation to marsh management. Retrospective Theses and Dissertations

Bedish JW (1967) Cattail moisture requirements and their significance to marsh management. American Midland Naturalist:288-300

Bellrose FC (1950) The relationship of muskrat populations to various marsh and aquatic plants. The Journal of Wildlife Management 14: 299-315

Bellrose FC, Brown LG (1941) The effect of fluctuating water levels on the muskrat population of the Illinois River valley. The Journal of Wildlife Management 5:206-212

Bendix M, Tornbjerg T, Brix H (1994) Internal gas transport in Typha latifolia L. and Typha angustifolia L. 1. Humidity-induced pressurization and convective throughflow. Aquatic Botany 49:75-89

Berke K (2017) Nutrient removal and vegetation recovery through successive harvesting of the invasive hybrid cattail (Typha $\times$ glauca) in Great Lakes coastal wetlands. Thesis, Loyola University

Berry P, Yassin F, Grosshans R, Lindenschmidt K-E (2017) Surface water retention systems for cattail production as a biofuel. Journal of Environmental Management 203:500-509

Beule JD (1979) Control and management of cattails in southeastern Wisconsin wetlands. Wisconsin Department of Natural Resources Technical Bulletin No. 112

Bhatia M, Goyal D (2014) Analyzing remediation potential of wastewater through wetland plants: a review. Environmental Progress \& Sustainable Energy 33:9-27

Bhomia RK, Inglett PW, Reddy KR (2015) Soil and phosphorus accretion rates in sub-tropical wetlands: Everglades Stormwater treatment areas as a case example. Science of the Total Environment 533: 297-306

Biswas K (2015) Biological agents of bioremediation: a concise review. Frontiers in Environmental Microbiology 1:39-43

Boers AM, Zedler JB (2008) Stabilized water levels and Typha invasiveness. Wetlands 28:676-685

Boers AM, Veltman RLD, Zedler JB (2007) Typha×glauca dominance and extended hydroperiod constrain restoration of wetland diversity. Ecological Engineering 29:232-244

Bonanno G, Cirelli GL (2017) Comparative analysis of element concentrations and translocation in three wetland congener plants: Typha domingensis, Typha latifolia and Typha angustifolia. Ecotoxicology and Environmental Safety 143:92-101

Bonnewell V, Koukkari WL, Pratt DC (1983) Light, oxygen, and temperature requirements for Typha latifolia seed germination. Canadian Journal of Botany 61:1330-1336

Borokoni T, Babalola F (2012) Management of invasive plant species in Nigeria through economic exploitation: lessons from other countries. Management of Biological Invasions 3:45-55

Boxem R, Davis EL, Vermaire JC (2018) Long-term environmental change and shifts in the aquatic plant community of Jones Creek, Thousand Islands National Park, Ontario, Canada based on plant macrofossil analysis. Journal of Paleolimnology 60:349-360

Boyd CE, Hess LW (1970) Factors influencing shoot production and mineral nutrient levels in Typha latifolia. Ecology 51:296-300 
Bratton SP (1974) The effect of the European wild boar (Sus scrofa) on the high-elevation vernal flora in Great Smoky Mountains National Park. Bulletin of the Torrey Botanical Club 101:198-206

Brazner JC, Danz NP, Niemi GJ, Regal RR, Trebitz AS, Howe RW, Hanowski JM, Johnson LB, Ciborowski JJH, Johnston CA, Reavie ED, Brady VJ, Sgro GV (2007) Evaluation of geographic, geomorphic and human influences on Great Lakes wetland indicators: a multi-assemblage approach. Ecological Indicators 7:610-635

Brown SC, Bedford BL (1997) Restoration of wetland vegetation with transplanted wetland soil: An experimental study. Wetlands 17:424 437

Buckley YM, Rees M, Paynter Q, Lonsdale M (2004) Modelling integrated weed management of an invasive shrub in tropical Australia. Journal of Applied Ecology 41:547-560

Buhler DD (2002) Challenges and opportunities for integrated weed management. Weed Science 50:273-280

Bunbury-Blanchette AL, Freeland JR, Dorken ME (2015) Hybrid Typha $\times$ glauca outperforms native T. latifolia under contrasting water depths in a common garden. Basic and Applied Ecology 16:394402

Bunch AJ, Allen MS, Gwinn DC (2010) Spatial and temporal hypoxia dynamics in dense emergent macrophytes in a Florida lake. Wetlands 30:429-435

Bunch AJ, Allen MS, Gwinn DC (2015) Influence of macrophyteinduced hypoxia on fish communities in lakes with altered hydrology. Lake and Reservoir Management 31:11-19

Burke MJW, Grime JP (1996) An experimental study of plant community invasibility. Ecology 77:776-790

CABI (2018a) Typha x glauca. In: Invasive Species Compendium. Available via CABI. https://www.cabi.org/ISC/datasheet/107745. Accessed 22Oct 2018

CABI (2018b) Typha latifolia. In: Invasive Species Compendium. Available via CABI. https://www.cabi.org/ISC/datasheet/54297. Accessed 22 Oct 2018

CABI (2018c) Typha angustifolia. In: Invasive Species Compendium. Available via CABI. https://www.cabi.org/ISC/datasheet/54294. Accessed 22 Oct 2018

CABI (2018d) Typha domingensis. In: Invasive Species Compendium. Available via CABI. https://www.cabi.org/ISC/datasheet/54296. Accessed 22 Oct 2018

Calderone NW (2012) Insect pollinated crops, insect pollinators and US agriculture: trend analysis of aggregate data for the period 19922009. PLoS One 7:e37235

Campbell KL, MacArthur RA (1994) Digestibility and assimilation of natural forages by muskrat. The Journal of Wildlife Management 58:633-641

Cantrell MA (1981) Bilharzia snails and water level fluctuations in a tropical swamp. Oikos 36:226-232

Cardinale BJ, Burton TM, Brady VJ (1997) The community dynamics of epiphytic midge larvae across the pelagic-littoral interface: do animals respond to changes in the abiotic environment? Canadian Journal of Fisheries and Aquatic Sciences 54:2314-2322

Carmichael MJ, Bernhardt ES, Bräuer SL, Smith WK (2014) The role of vegetation in methane flux to the atmosphere: should vegetation be included as a distinct category in the global methane budget? Biogeochemistry 119:1-24

Carney CE, deNoyelles F Jr (1986) Grass carp as a potential control agent for cattails. Transactions of the Kansas Academy of Science 89:8689

Carson BD, Lishawa SC, Tuchman NC, Monks AM, Lawrence BA, Albert DA (2018) Harvesting invasive plants to reduce nutrient loads and produce bioenergy: an assessment of Great Lakes coastal wetlands. Ecosphere 9:e02320

Chabbi A, McKee KL, Mendelssohn IA (2000) Fate of oxygen losses from Typha domingensis (Typhaceae) and Cladium jamaicense
(Cyperaceae) and consequences for root metabolism. American Journal of Botany 87:1081-1090

Chanton JP, Whiting GJ (1996) Methane stable isotopic distributions as indicators of gas transport mechanisms in emergent aquatic plants. Aquatic Botany 54:227-236

Chanton JP, Whiting GJ, Happell JD, Gerard G (1993) Contrasting rates and diurnal patterns of methane emission from emergent aquatic macrophytes. Aquatic Botany 46:111-128

Chen H, Vaughan K (2014) Influence of inundation depth on Typha domingensis and its implication for phosphorus removal in the Everglades stormwater treatment area. Wetlands 34:325-334

Chen H, Zamorano MF, Ivanoff D (2010) Effect of flooding depth on growth, biomass, photosynthesis, and chlorophyll fluorescence of Typha domingensis. Wetlands 30:957-965

Chen Y, Wen Y, Zhou Q, Vymazal J (2014) Effects of plant biomass on nitrogen transformation in subsurface-batch constructed wetlands: a stable isotope and mass balance assessment. Water Research 63: $158-167$

Chen H, Ivanoff D, Pietro K (2015) Long-term phosphorus removal in the Everglades stormwater treatment areas of South Florida in the United States. Ecological Engineering 79:158-168

Cheng X, Peng R, Chen J, Luo Y, Zhang Q, An S, Chen J, Li B (2007) $\mathrm{CH}_{4}$ and $\mathrm{N}_{2} \mathrm{O}$ emissions from Spartina alterniflora and Phragmites australis in experimental mesocosms. Chemosphere 68:420-427

Childers DL, Doren RF, Jones R, Noe GB, Rugge M, Scinto LJ (2003) Decadal change in vegetation and soil phosphorus pattern across the Everglades landscape. Journal of Environmental Quality 32:344 362

Chimney MJ (ed) (2018) Chapter 5B: Performance and Operation of the Everglades Stormwater Treatment Areas. In: 2018 South Florida Environmental Report. South Florida Water Management District. Available via SFWMD http://apps.sfwmd.gov/sfwmd/SFER/2018 sfer_final/v1/chapters/v1_ch5b.pdf. Accessed 22 Oct 2018

Chimney MJ, Goforth G (2001) Environmental impacts to the Everglades ecosystem: a historical perspective and restoration strategies. Water Science and Technology 44:93-100

Chimney MJ, Pietro KC (2006) Decomposition of macrophyte litter in a subtropical constructed wetland in South Florida (USA). Ecological Engineering 27:301-321

Christensen JR, Crumpton WG (2010) Wetland invertebrate community responses to varying emergent litter in a prairie pothole emergent marsh. Wetlands 30:1031-1043

Cicek N, Lambert S, Venema HD, Snelgrove KR, Bibeau EL, Grosshans R (2006) Nutrient removal and bio-energy production from NetleyLibau Marsh at Lake Winnipeg through annual biomass harvesting. Biomass and Bioenergy 30:529-536

Ciotir C, Freeland J (2016) Cryptic intercontinental dispersal, commercial retailers, and the genetic diversity of native and non-native cattails (Typha spp.) in North America. Hydrobiologia 768:137-150

Ciotir C, Kirk H, Row JR, Freeland JR (2013) Intercontinental dispersal of Typha angustifolia and T. latifolia between Europe and North America has implications for Typha invasions. Biological Invasions 15:1377-1390

Ciotir C, Szabo J, Freeland J (2017) Genetic characterization of cattail species and hybrids (Typha spp.) in Europe. Aquatic Botany 141: $51-59$

Ciria MP, Solano ML, Soriano P (2005) Role of macrophyte Typha latifolia in a constructed wetland for wastewater treatment and assessment of its potential as a biomass fuel. Biosystems Engineering 92:535-544

Clark WR (1994) Habitat selection by muskrats in experimental marshes undergoing succession. Canadian Journal of Zoology 72:675-680

Cogels FX, Coly A, Niang A (1997) Impact of dam construction on the hydrological regime and quality of a Sahelian lake in the river Senegal basin. Regulated Rivers: Research \& Management 13:2741 
Colbers B, Cornelis S, Geraets E, Gutiérrez-Valdés N, Tran LM, MorenoGiménez E, Ramírez-Gaona M (2017) A feasibility study on the usage of cattail (Typha spp.) for the production of insulation materials and bio-adhesives. Available via WURC http://edepot.wur.nl/ 429929. Accessed 1 Sept 2018

Comes RD, Kelley AD (1989) Control of common Typha with postemergence herbicides. Journal of Aquatic Plant Management 27: 20-23

Connors LM, Kiviat E, Groffman PM, Ostfeld RS (2000) Muskrat (Ondatra zibethicus) disturbance to vegetation and potential net nitrogen mineralization and nitrification rates in a freshwater tidal marsh. The American Midland Naturalist 143:53-63

Coon WF, Bernard JM, Seischab FK Effects of a cattail wetland on water quality of Irondequoit Creek near Rochester. U. S. Geological Survey Water-Resources Investigations Report, New York, pp 2000, 2000-4032

Cooper JE, Mead JV, Farrell JM, Werner RG (2008) Potential effects of spawning habitat changes on the segregation of northern pike (Esox lucius) and muskellunge (E. masquinongy) in the upper St. Lawrence River. Hydrobiologia 601:41-53

Corns WG, Gupta RK (1971) Chemical control of cattail, Typha latifolia. Canadian Journal of Plant Science 51:491-497

Cowardin LM, Carter V, Golet FC, LaRoe ET (1979) Classification of wetlands and deepwater habitats of the United States. U.S. Department of the Interior, Fish and Wildlife Service, Office of Biological Services FWS/OBS-79/31

Craft CB, Richardson CJ (1997) Relationships between soil nutrients and plant species composition in Everglades peatlands. Journal of Environmental Quality 26:224-232

Crain CM, Silliman BR, Bertness SL, Bertness MD (2004) Physical and biotic drivers of plant distribution across estuarine salinity gradients. Ecology 85:2539-2549

Cressey R (2016) Changes in wetland conditions and wetland plant communities in the Prairie Pothole Region after 50 years. Thesis, South Dakota State University

Currie WS, Goldberg DE, Martina J, Wildova R, Farrer E, Elgersma KJ (2014) Emergence of nutrient-cycling feedbacks related to plant size and invasion success in a wetland community-ecosystem model. Ecological Modelling 282:69-82

Dahl TE (1990) Wetland losses in the United States 1780's to 1980's. U.S. Department of the Interior, fish and wildlife service, Washington, D.C, p 13

Dahl TE (2014) Status and trends of prairie wetlands in the United States 1997 to 2009. U.S. Department of the Interior, Fish and Wildlife Service, Washington, D.C., p 67

Danell K (1979) Reduction of aquatic vegetation following the colonization of a northern Swedish lake by the muskrat, Ondatra zibethica. Oecologia 38:101-106

Davis JH (1943) The natural features of southern Florida, especially the vegetation, and the Everglades. State of Florida Department of Conservation, Florida Geological Survey Geological Bulletin No. 25

Davis SM (1991) Growth, decomposition, and nutrient retention of Cladium jamaicense Crantz and Typha domingensis Pers. in the Florida Everglades. Aquatic Botany 40:203-224

Davis SM (1994) Phosphorus inputs and vegetation sensitivity in the Everglades. In: Davis SM, Ogden JC (eds) Everglades: the ecosystem and its restoration. St. Lucie Press, Delray Beach, pp 357-378

Davis SM, Ogden JC (eds) (1994) Everglades: the ecosystem and its restoration. St. Lucie Press, Delray Beach

Davis CB, van der Valk AG (1978) The decomposition of standing and fallen litter of Typha glauca and Scirpus fluviatilis. Canadian Journal of Botany 56:662-675

de Swart EOAM, van der Valk AG, Koehler KJ, Barendregt A (1994) Experimental evaluation of realized niche models for predicting responses of plant species to a change in environmental conditions. Journal of Vegetation Science 5:541-552

Degeorges A, Reilly BK (2006) Dams and large scale irrigation on the Senegal River: impacts on man and the environment. International Journal of Environmental Studies 63:633-644

Demirezen D, Aksoy A (2004) Accumulation of heavy metals in Typha angustifolia (L.) and Potamogeton pectinatus (L.) living in sultan Marsh (Kayseri, Turkey). Chemosphere 56:685-696

Dierberg FE, DeBusk TA (2008) Particulate phosphorus transformations in South Florida stormwater treatment areas used for Everglades protection. Ecological Engineering 34:100-115

Dolbeer RA (1990) Ornithology and integrated pest management: redwinged blackbirds Agelaius phoeniceus and corn. Ibis 132:309-322

Dubbe DR, Garver EG, Pratt DC (1988) Production of cattail (Typha spp.) biomass in Minnesota, USA. Biomass 17:79-104

Dugger BD, Moore ML, Finger RS, Petrie MJ (2007) True metabolizable energy for seeds of common moist-soil plant species. The Journal of Wildlife Management 71:1964-1967

Ehrenfeld JG (2010) Ecosystem consequences of biological invasions. Annual Review of Ecology, Evolution, and Systematics 41:59-80

Ekstam B, Forseby Å (1999) Germination response of Phragmites australis and Typha latifolia to diurnal fluctuations in temperature. Seed Science Research 9:157-163

Elgersma KJ, Martina JP, Goldberg DE, Currie WS (2017) Effectiveness of cattail (Typha spp.) management techniques depends on exogenous nitrogen inputs. Elementa: Science of Anthropocene 5

Elhaak MA, Mohsen AA, Hamada E-SAM, El-Gebaly FE (2015) Biofuel production from Phragmites australis (cav.) and Typha domingensis (pers.) plants of Burullus Lake. Egyptian Journal of Experimental Biology 11:237-243

Ellstrand NC, Schierenbeck KA (2000) Hybridization as a stimulus for the evolution of invasiveness in plants? Proceedings of the National Academy of Sciences 97:7043-7050

Errington PL (1939) Reaction of muskrat populations to drought. Ecology 20:168-186

Euliss NH Jr, Mushet DM (1996) Water-level fluctuation in wetlands as a function of landscape condition in the prairie pothole region. Wetlands 16:587-593

Euliss NH Jr, Mushet DM (2011) A multi-year comparison of IPCI scores for prairie pothole wetlands: implications of temporal and spatial variation. Wetlands 31:713-723

Euliss NH Jr, LaBaugh JW, Fredrickson LH, Mushet DM, Laubhan MK, Swanson GA, Winter TC, Rosenberry DO, Nelson RD (2004) The wetland continuum: a conceptual framework for interpreting biological studies. Wetlands 24:448-458

Euliss NH Jr, Gleason RA, Olness A, McDougal RL, Murkin HR, Robarts RD, Bourbonniere RA, Warner BG (2006) North American prairie wetlands are important nonforested land-based carbon storage sites. Science of the Total Environment 361:179-188

Euliss NH Jr, Mushet DM, Newton WE, Otto CRV, Nelson RD, LaBaugh JW, Scherff EJ, Rosenberry DO (2014) Placing prairie pothole wetlands along spatial and temporal continua to improve integration of wetland function in ecological investigations. Journal of Hydrology 513:490-503

Farney RA, Bookhout TA (1982) Vegetation changes in a Lake Erie marsh (Winous Point, Ottawa County, Ohio) during high water years

Farrell JM, Murry BA, Leopold DJ, Halpern A, Rippke MB, Godwin KS, Hafner SD (2010) Water-level regulation and coastal wetland vegetation in the upper St. Lawrence River: inferences from historical aerial imagery, seed banks, and Typha dynamics. Hydrobiologia 647:127-144

Farrer EC, Goldberg DE (2009) Litter drives ecosystem and plant community changes in cattail invasion. Ecological Applications 19:398412 
Faußer AC, Hoppert M, Walther P, Kazda M (2012) Roots of the wetland plants Typha latifolia and Phragmites australis are inhabited by methanotrophic bacteria in biofilms. Flora - Morphology, Distribution, Functional Ecology of Plants 207:775-782

Finkelstein SA (2003) Identifying pollen grains of Typha latifolia, Typha angustifolia, and Typha $\times$ glauca. Canadian Journal of Botany 81: 985-990

Finkelstein SA, Peros MC, Davis AM (2005) Late Holocene paleoenvironmental change in a Great Lakes coastal wetland: integrating pollen and diatom datasets. Journal of Paleolimnology 33:112

Finlayson M, Forrester RI, Mitchell DS, Chick AJ (1985) Identification of native Typha species in Australia. Australian Journal of Botany 33:101-107

Fischer H, Meissner KJ, Mix AC, Abram NJ, Austermann J, Brovkin V, Capron E, Colombaroli D, Daniau AL, Dyez KA (2018) Palaeoclimate constraints on a world with post-industrial warming of 2 degrees and beyond. Nature Geoscience

Flora of North America (2000) Flora of North America north of Mexico, volume 22: Magnoliophyta: Alismatidae, Arecidae, Commelinidae (in part), and Zingiberidae. Oxford University Press, New York

Foloni LL, Pitelli RA (2005) Avaliação da sensibilidade de diversas espécies de plantas daninhas aquáticas ao carfentrazone-ethyl, em ambiente controlado. Planta Daninha 23:329-334

Forcey GM, Thogmartin WE (2017) Effects of habitat and climate on blackbird populations. In: Linz GM, Avery ML, Dolbeer RA (eds) Ecology and Management of Blackbirds (Icteridae) in North America. CRC Press, Boca Raton, pp 101-118

Freeland J, Ciotir C, Kirk H (2013) Regional differences in the abundance of native, introduced, and hybrid Typha spp. in northeastern North America influence wetland invasions. Biological Invasions 15: 2651-2665

Freeland JR, Ciotir C, Wensink L, Dorken M (2017) Widespread cytonuclear discordance in narrow-leaved cattail (Typha angustifolia) does not explain the dominance of its invasive hybrid (Typha $\times$ glauca). Hydrobiologia 792:53-65

Frieswyk CB, Zedler JB (2007) Vegetation change in Great Lakes coastal wetlands: deviation from the historical cycle. Journal of Great Lakes Research 33:366-380

Frieswyk CB, Johnston CA, Zedler JB (2007) Identifying and characterizing dominant plants as an indicator of community condition. Journal of Great Lakes Research 33:125-135

Fritzell EK (1989) Mammals in the prairie wetlands. In: Van der Valk AG (ed) Northern prairie wetlands. Iowa State University Press, Ames, pp 268-301

Gaiser EE, Trexler JC, Richards JH, Childers DL, Lee D, Edwards AL, Scinto LJ, Jayachandran K, Noe GB, Jones RD (2005) Cascading ecological effects of low-level phosphorus enrichment in the Florida Everglades. Journal of Environmental Quality 34:717-723

Gaiser EE, McCormick PV, Hagerthey SE, Gottlieb AD (2011) Landscape patterns of periphyton in the Florida Everglades. Critical Reviews in Environmental Science and Technology 41: 92-120

Galatowitsch SM, van der Valk AG (1996) The vegetation of restored and natural prairie wetlands. Ecological Applications 6:102-112

Galatowitsch SM, Anderson NO, Ascher PD (1999) Invasiveness in wetland plants in temperate North America. Wetlands 19:733-755

Galinato MI, van der Valk AG (1986) Seed germination traits of annuals and emergents recruited during drawdowns in the Delta Marsh, Manitoba, Canada. Aquatic Botany 26:89-102

Gallant AL, Euliss NH Jr, Browning Z (2014) Mapping large-area landscape suitability for honey bees to assess the influence of land-use change on sustainability of national pollination services. PLoS One 9:e99268

Gallardo MT, Martin BB, Martin DF (1998) Inhibition of water fern Salvinia minima by cattail (Typha domingensis) extracts and by 2 - chlorophenol and salicylaldehyde. Journal of Chemical Ecology 24: $1483-1490$

Galle AM, Linz GM, Homan HJ, Bleier WJ (2009) Avian use of harvested crop fields in North Dakota during spring migration. Western North American Naturalist:491-500

Gann D, Richards JH (2014) WorldView-2 applications: Methodological testing and capability in relation to vegetation monitoring in the Everglades. Available via FIU. http://digitalcommons.fiu.edu/gis/ 26. Accessed 10 Dec 2018

Gann GD, Stocking CG, Collaborators (2001-2018) Floristic inventory of south Florida database online. Available via FISF. https:// regionalconservation.org/ircs/database/database.asp. Accessed 1 Sept 2018

Garver EG, Dubbe DR, Pratt DC (1988) Seasonal patterns in accumulation and partitioning of biomass and macronutrients in Typha spp. Aquatic Botany 32:115-127

Gates FC (1912) The vegetation of the beach area in northeastern Illinois and southeastern Wisconsin. Bulletin of the Illinois State Laboratory of Natural History (Vol 9), Urbana

Gebremariam SY, Beutel MW (2008) Nitrate removal and DO levels in batch wetland mesocosms: cattail (Typha spp.) versus bulrush (Scirpus spp.). Ecological Engineering 34:1-6

Geddes P, Grancharova T, Kelly JJ, Treering D, Tuchman NC (2014) Effects of invasive Typha $\times$ glauca on wetland nutrient pools, denitrification, and bacterial communities are influenced by time since invasion. Aquatic Ecology 48:247-258

Glahn JF, Richard DF, Hill EP (1994) Historical use of bamboo/cane as blackbird and starling roosting habitat: implications for roost management. Journal of Field Ornithology 65:237-246

Gleason RA, Euliss NH, Jr. (1998) Sedimentation of prairie wetlands. Great Plains Research 8:97-112

Gleason RA, Euliss NH Jr, Hubbard DE, Duffy WG (2003) Effects of sediment load on emergence of aquatic invertebrates and plants from wetland soil egg and seed banks. Wetlands 23:26-34

Gleason RA, Tangen BA, Laubhan MK, Finocchiaro RG, Stamm JF (2009) Literature review and database of relations between salinity and aquatic biota-applications to Bowdoin National Wildlife Refuge, Montana. U.S. Geological Survey Scientific Investigations Report:2009-5059

Gleason RA, Tangen BA, Laubhan MK, Lor S (2012) A multi-refuge study to evaluate the effectiveness of growing-season and dormantseason burns to control cattail. U.S. Geological Survey Scientific Investigations Report 2012-5143

Glenn E, Thompson TL, Frye R, Riley J, Baumgartner D (1995) Effects of salinity on growth and evapotranspiration of Typha domingensis Pers. Aquatic Botany 52:75-91

Goldhaber MB, Mills CT, Morrison JM, Stricker CA, Mushet DM, LaBaugh JW (2014) Hydrogeochemistry of prairie pothole region wetlands: role of long-term critical zone processes. Chemical Geology 387:170-183

Gomes MVT, de Souza RR, Teles VS, Araújo Mendes É (2014) Phytoremediation of water contaminated with mercury using Typha domingensis in constructed wetland. Chemosphere 103: 228-233

Gottschall N, Boutin C, Crolla A, Kinsley C, Champagne P (2007) The role of plants in the removal of nutrients at a constructed wetland treating agricultural (dairy) wastewater, Ontario, Canada. Ecological Engineering 29:154-163

Grace JB (1988) The effects of nutrient additions on mixtures of Typha latifolia L. and Typha domingensis pers. along a water-depth gradient. Aquatic Botany 31:83-92

Grace JB (1989) Effects of water depth on Typha latifolia and Typha domingensis. American Journal of Botany 76:762-768

Grace JB, Harrison JS (1986) The biology of Canadian weeds.: 73. Typha latifolia L., Typha angustifolia L. and Typha x glauca Godr. Canadian Journal of Plant Science 66:361-379 
Grace JB, Wetzel RG (1981) Habitat partitioning and competitive displacement in cattails (Typha): experimental field studies. The American Naturalist 118:463-474

Grace JB, Wetzel RG (1982a) Niche differentiation between two rhizomatous plant species: Typha latifolia and Typha angustifolia. Canadian Journal of Botany 60:46-57

Grace JB, Wetzel RG (1982b) Variations in growth and reproduction within populations of two rhizomatous plant species: Typha latifolia and Typha angustifolia. Oecologia 53:258-263

Graves EE, Holyoak M, Rodd Kelsey T, Meese RJ (2013) Understanding the contribution of habitats and regional variation to long-term population trends in tricolored blackbirds. Ecology and Evolution 3: 2845-2858

Greer AK, Dugger BD, Graber DA, Petrie MJ (2007) The effects of seasonal flooding on seed availability for spring migrating waterfowl. The Journal of Wildlife Management 71:1561-1566

Gronewold AD, Clites AH, Smith JP, Hunter TS (2013) A dynamic graphical interface for visualizing projected, measured, and reconstructed surface water elevations on the earth's largest lakes. Environmental Modelling \& Software 49:34-39

Grosshans RE (2001) Long-term vegetation dynamics following water level stabilization in a prairie marsh. Thesis, University of Manitoba

Grosshans RE (2014) Cattail (Typha spp.) biomass harvesting for nutrient capture and sustainable bioenergy for integrated watershed management. Dissertation, University of Manitoba

Grosshans RE, Wrubleski DA, Goldsborough LG (2004) Changes in the emergent plant community of Netley-Libau Marsh between 1979 and 2001. Available via University of Manitoba https://mspace.lib. umanitoba.ca/handle/1993/32048. Accessed 11 Dec 2018

Grosshans RE, Dohan R, Roy D, Venema HD, McCandless M (2013) Cattail harvesting for carbon offsets and nutrient capture: A" lake friendly" greenhouse gas project. Available via IISD https://www. iisd.org/library/cattails-harvesting-carbon-offsets-and-nutrientcapture-lake-friendly-greenhouse-gas-project. Accessed 11 Dec 2018

Grosshans RE, Grieger L, Ackerman J, Gauthier S, Swystun K, Gass P, Roy D (2014) Cattail biomass in a watershed-based bioeconomy: Commercial-scale harvesting and processing for nutrient capture, biocarbon, and high-value bioproducts. Available via IISD https:// www.iisd.org/library/cattail-biomass-watershed-basedbioeconomy-commercial-scale-harvesting-and-processing. Accessed 11 Dec 2018

Groudev S, Georgiev P, Spasova I, Nicolova M (2008) Bioremediation of acid mine drainage in a uranium deposit. Hydrometallurgy 94:93-99

Gunderson LH (1994) Vegetation of the Everglades: determinants of community composition. In: Davis SM, Ogden JC (eds) Everglades: the ecosystem and its restoration. St. Lucie Press, Delray Beach, pp 323-340

Hagerthey SE, Bellinger BJ, Wheeler K, Gantar M, Gaiser E (2011) Everglades periphyton: a biogeochemical perspective. Critical Reviews in Environmental Science and Technology 41:309-343

Hagerthey SE, Cook MI, Mac Kobza R, Newman S, Bellinger BJ (2014) Aquatic faunal responses to an induced regime shift in the phosphorus-impacted Everglades. Freshwater Biology 59:13891405

Hagy HM, Kaminski RM (2012) Apparent seed use by ducks in moistsoil wetlands of the Mississippi Alluvial Valley. The Journal of Wildlife Management 76:1053-1061

Hagy HM, Linz GM, Bleier WJ (2008) Optimizing the use of decoy plots for blackbird control in commercial sunflower. Crop Protection 27: $1442-1447$

Hall SJ, Zedler JB (2010) Constraints on sedge meadow self-restoration in urban wetlands. Restoration Ecology 18:671-680

Hall SJ, Lindig-Cisneros R, Zedler JB (2008) Does harvesting sustain plant diversity in central Mexican wetlands? Wetlands 28:776-792
Hamdoun AM, El Tigani KB (1977) Weed control problems in the Sudan. PANS 23:190-194

Harris SW, Marshall WH (1963) Ecology of water-level manipulations on a northern marsh. Ecology 44:331-343

Haukos DA, Smith LM (1993) Moist-soil management of playa lakes for migrating and wintering ducks. Wildlife Society Bulletin 21:288298

Hawaii Invasive Species Council (2008) Cattail (Typha latifolia). Available via HISP. https://dlnr.hawaii.gov/hisc/info/invasivespecies-profiles/cattail/. Accessed 1 Sept 2018

Hayashi M, van der Kamp G, Rosenberry DO (2016) Hydrology of prairie wetlands: understanding the integrated surface-water and groundwater processes. Wetlands 36:237-254

He S, Malfatti SA, McFarland JW, Anderson FE, Pati A, Huntemann M, Tremblay J, Glavina del Rio T, Waldrop MP, Windham-Myers L, Tringe SG (2015) Patterns in wetland microbial community composition and functional gene repertoire associated with methane emissions. $\mathrm{mBio} 6$

Headley TR, Tanner CC (2012) Constructed wetlands with floating emergent macrophytes: an innovative stormwater treatment technology. Critical Reviews in Environmental Science and Technology 42: 2261-2310

Hegazy AK, Abdel-Ghani NT, El-Chaghaby GA (2011) Phytoremediation of industrial wastewater potentiality by Typha domingensis. International journal of Environmental Science and Technology 8:639-648

Hellsten S, Dieme C, Mbengue M, Janauer GA, den Hollander N, Pieterse AH (1999) Typha control efficiency of a weed-cutting boat in the lac de Guiers in Senegal: a preliminary study on mowing speed and re-growth capacity. Hydrobiologia 415:249-255

Herrero J, Couto S, Rosell C, Arias P (2004) Preliminary data on the diet of wild boar living in a Mediterranean coastal wetland. Galemys 16: $115-123$

Herrick BM, Wolf AT (2005) Invasive plant species in diked vs. undiked Great Lakes wetlands. Journal of Great Lakes Research 31:277-287

Hilgartner WB, Brush GS (2006) Prehistoric habitat stability and postsettlement habitat change in a Chesapeake Bay freshwater tidal wetland, USA. The Holocene 16:479-494

Hill N (2017) Marshbird response to invasive cattail control using grazing, mowing, and herbicide, application in the Prairie Pothole Region of Minnesota. Available via USFWS https://www.fws.gov/ migratorybirds/pdf/surveys-and-data/Webless $\% 20$ Migratory $\%$ $20 \mathrm{Game} \% 20 \mathrm{Birds} / \mathrm{Marsh} \% 20 \mathrm{Bird} \% 20 \mathrm{pdf} \% 20$ files/ MarshbirdResponseToInvasiveCattailControlInMN.pdf. Accessed 1 Sept 2018

Hill NM, Keddy PA, Wisheu IC (1998) A hydrological model for predicting the effects of dams on the shoreline vegetation of lakes and reservoirs. Environmental Management 22:723-736

Hogg EH, Wein RW (1987) Growth dynamics of floating Typha mats: seasonal translocation and internal deposition of organic material. Oikos 50:197-205

Holm LG, Doll J, Holm E, Pancho JV, Herberger JP (1997) World weeds: natural histories and distribution. John Wiley \& Sons, New York

Holyoak M, Meese RJ, Graves EE (2014) Combining site occupancy, breeding population sizes and reproductive success to calculate time-averaged reproductive output of different habitat types: An application to tricolored blackbirds. PLoS One 9:e96980

Homan HJ, Linz GM, Bleier WJ (2000) Winter habitat use and survival of female ring-necked pheasants (Phasianus colchicus) in southeastern North Dakota. The American Midland Naturalist 143:463-480

Homan HJ, Linz GM, Carlson RC, Bleier WJ (2003) Spring distribution of ring-necked pheasants (Phasianus colchicus) following cattail reduction with glyphosate herbicide. Wildlife Research 30:159-166

Homan HJ, Sawin RS, Linz GM, Bleier WJ (2006) Habitat characteristics of spring blackbird roosts in east-Central South Dakota. Prairie Naturalist 38:183 
Hood WG (2013) Applying and testing a predictive vegetation model to management of the invasive cattail, Typha angustifolia L., in an oligohaline tidal marsh reveals priority effects caused by non-stationarity. Wetlands Ecology and Management 21:229-242

Höök TO, Eagan NM, Webb PW (2001) Habitat and human influences on larval fish assemblages in northern Lake Huron coastal marsh bays. Wetlands 21:281-291

Horppila J, Nurminen L (2001) The effect of an emergent macrophyte (Typha angustifolia) on sediment resuspension in a shallow north temperate lake. Freshwater Biology 46:1447-1455

Howe CM, Berrill M, Pauli BD, Helbing CC, Werry K, Veldhoen N (2004) Toxicity of glyphosate-based pesticides to four north American frog species. Environmental Toxicology and Chemistry 23:1928-1938

Hudon C, Wilcox D, Ingram J (2006) Modeling wetland plant community response to assess water-level regulation scenarios in the Lake Ontario-St. Lawrence River basin. Environmental Monitoring and Assessment 113:303-328

Hurst E (1942) The poison plants of New South Wales. New South Wales poison plants committee, Sydney

Jacob DL, Otte ML (2004) Influence of Typha latifolia and fertilization on metal mobility in two different $\mathrm{Pb}-\mathrm{Zn}$ mine tailings types. Science of the Total Environment 333:9-24

Jarchow ME, Cook BJ (2009) Allelopathy as a mechanism for the invasion of Typha angustifolia. Plant Ecology 204:113-124

Jeke NN, Zvomuya F, Cicek N, Ross L, Badiou P (2015) Biomass, nutrient, and trace element accumulation and partitioning in cattail (Typha latifolia L.) during wetland phytoremediation of municipal biosolids. Journal of Environmental Quality 44:1541-1549

Johnson RR, Dinsmore JJ (1986) Habitat use by breeding Virginia rails and soras. The Journal of Wildlife Management 50:387-392

Jordan TE, Whigham DF (1988) The importance of standing dead shoots of the narrow leaved cattail, Typha angustifolia L. Aquatic Botany 29:319-328

Jordan TE, Whigham DF, Correll DL (1989) The role of litter in nutrient cycling in a brackish tidal marsh. Ecology 70:1906-1915

Jordan TE, Whigham DF, Correll DL (1990) Effects of nutrient and litter manipulations on the narrow-leaved cattail, Typha angustifolia $\mathrm{L}$. Aquatic Botany 36:179-191

Jurik TW, Wang S-C, van der Valk AG (1994) Effects of sediment load on seedling emergence from wetland seed banks. Wetlands 14:159-165

Juston JM, DeBusk TA (2006) Phosphorus mass load and outflow concentration relationships in stormwater treatment areas for Everglades restoration. Ecological Engineering 26:206-223

Juston JM, DeBusk TA (2011) Evidence and implications of the background phosphorus concentration of submerged aquatic vegetation wetlands in Stormwater Treatment Areas for Everglades restoration. Water Resources Research 47

Juston JM, DeBusk TA, Grace KA, Jackson SD (2013) A model of phosphorus cycling to explore the role of biomass turnover in submerged aquatic vegetation wetlands for Everglades restoration. Ecological Modelling 251:135-149

Kadlec RH, Wallace S (2009) Treatment wetlands. CRC Press, Boca Raton

Kantrud HA (1986) Effects of vegetation manipulation on breeding waterfowl in prairie wetlands-A literature review. Available via DTIC http://www.dtic.mil/dtic/tr/fulltext/u2/a323112.pdf. Accessed 1 Sept 2018

Kantrud HA (1992) History of cattails on the prairies: wildlife impacts. In Linz GM (ed) Proceedings of the cattail management symposium, Fargo, pp 9-12. Available via USDA. https://www.aphis.usda.gov/ wildlife damage/nwrc/publications/92pubs/92-72.pdf. Accessed 1 Sept $20 \overline{18}$

Kantrud HA, Newton WE (1996) A test of vegetation-related indicators of wetland quality in the prairie pothole region. Journal of Aquatic Ecosystem Health 5:177-191
Kao-Kniffin J, Freyre DS, Balser TC (2010) Methane dynamics across wetland plant species. Aquatic Botany 93:107-113

Kao-Kniffin J, Freyre DS, Balser TC (2011) Increased methane emissions from an invasive wetland plant under elevated carbon dioxide levels. Applied Soil Ecology 48:309-312

Kausch AP, Seago JL Jr, Marsh LC (1981) Changes in starch distribution in the overwintering organs of Typha latifolia (Typhaceae). American Journal of Botany 68:877-880

Keddy PA, Reznicek AA (1986) Great Lakes vegetation dynamics: the role of fluctuating water levels and buried seeds. Journal of Great Lakes Research 12:25-36

Kercher SM, Zedler JB (2004) Flood tolerance in wetland angiosperms: a comparison of invasive and noninvasive species. Aquatic Botany 80:89-102

Keyport S, Carson BD, Johnson O, Lawrence BA, Lishawa SC, Tuchman NC, Kelly JJ (2019) Effects of experimental harvesting of an invasive hybrid cattail on wetland structure and function. Restoration ecology 27:389-398King RS, Richardson CJ (2007) subsidystress response of macroinvertebrate community biomass to a phosphorus gradient in an oligotrophic wetland ecosystem. Journal of the North American Benthological Society 26:491-508

Kingsbury JM (1964) Poisonous plants of the United States and Canada. Soil Science 98:349

Kirby DR, Krabbenhoft KD, Sedivec KK, DeKeyser ES (2002) Wetlands in northern plains prairies: benefitting wildlife \& livestock. Rangelands 24:22-25

Kirk H, Connolly C, Freeland JR (2011) Molecular genetic data reveal hybridization between Typha angustifolia and Typha latifolia across a broad spatial scale in eastern North America. Aquatic Botany 95: 189-193

Kirschner AKT, Riegl B, Velimirov B (2001) Degradation of emergent and submerged macrophytes in an oxbow lake of an embanked backwater system: implications for the terrestrialization process. International Review of Hydrobiology 86:555-571

Klosterman ME, Linz GM, Slowik AA, Homan HJ (2013) Comparisons between blackbird damage to corn and sunflower in North Dakota. Crop Protection 53:1-5

Klug PE (2017) The future of blackbird management research. In: Linz GM, Avery ML, Dolbeer RA (eds) Ecology and Management of Blackbirds (Icteridae) in North America. CRC Press, Boca Raton, pp 217-234

Koch MS, Mendelssohn IA, McKee KL (1990) Mechanism for the hydrogen sulfide-induced growth limitation in wetland macrophytes. Limnology and Oceanography 35:399-408

Kong X, Wu W, Tian K, Jia Y, Siddiq A, Lin H, Tian X (2019) Promotive performance of shrimp Neocaridina denticulata on Typha angustifolia leaf litter decomposition. Hydrobiologia 827:75-87

Kostecke RM, Smith LM, Hands HM (2004) Vegetation response to cattail management at Cheyenne bottoms, Kansas. Journal of Aquatic Plant Management 42:39-45

Kostecke RM, Smith LM, Hands HM (2005) Macroinvertebrate response to cattail management at Cheyenne bottoms, Kansas, USA. Wetlands 25:758-763

Kowalski KP, Wilcox DA (1999) Use of historical and geospatial data to guide the restoration of a Lake Erie coastal marsh. Wetlands 19:858 868

Krapu GL, Reinecke KJ (1992) Foraging ecology and nutrition. In: Batt BDJ, Afton AD, Anderson MG, Ankney CD, Johnson DJ, Kadlec JA, Krapu GL (eds) Ecology and management of breeding waterfowl. University of Minnesota Press, Minneapolis, pp 1-29

Krapu GL, Pietz PJ, Brandt DA, Cox RR (2004) Does presence of permanent fresh water affect recruitment in prairie-nesting dabbling ducks? The Journal of Wildlife Management 68:332-341

Krecker FH (1939) A comparative study of the animal population of certain submerged aquatic plants. Ecology 20:553-562 
Krynak KL, Burke DJ, Benard MF (2017) Rodeo ${ }^{\mathrm{TM}}$ herbicide negatively affects Blanchard's cricket frogs (Acris blanchardi) survival and alters the skin-associated bacterial community. Journal of Herpetology 51:402-410

Kuhn NL, Mendelssohn IA, McKee KL, Lorenzen B, Brix H, Miao SL (2002) Root phosphatase activity in Cladium jamaicense and Typha domingensis grown under ambient and elevated phosphorus levels. Wetlands 22:794-800

Kumar S (2011) Aquatic weeds problems and management in India. Indian Journal of Weed Science 43:118-138

LaBaugh JW (1989) Chemical characteristics of water in northern prairie wetlands. In: Van der Valk AG (ed) Northern prairie wetlands. Iowa State University Press, Ames, pp 56-90

Lacki MJ, Peneston WT, Adams KB, Vogt FD, Houppert JC (1990) Summer foraging patterns and diet selection of muskrats inhabiting a fen wetland. Canadian Journal of Zoology 68:1163-1167

Larkin DJ, Freyman MJ, Lishawa SC, Geddes P, Tuchman NC (2012a) Mechanisms of dominance by the invasive hybrid cattail Typha $\times$ glauca. Biological Invasions 14:65-77

Larkin DJ, Lishawa SC, Tuchman NC (2012b) Appropriation of nitrogen by the invasive cattail Typha $\times$ glauca. Aquatic Botany 100:62-66

Larson DL, Royer RA, Royer MR (2006) Insect visitation and pollen deposition in an invaded prairie plant community. Biological Conservation 130:148-159

Larson DL, Droege S, Rabie PA, Larson JL, Devalez J, Haar M, McDermott-Kubeczko M (2014) Using a network modularity analysis to inform management of a rare endemic plant in the northern Great Plains, USA. Journal of Applied Ecology 51:1024-1032

Lawrence BA, Bourke K, Lishawa SC, Tuchman NC (2016a) Typha invasion associated with reduced aquatic macroinvertebrate abundance in northern Lake Huron coastal wetlands. Journal of Great Lakes Research 42:1412-1419

Lawrence BA, Lishawa SC, Rodriguez Y, Tuchman NC (2016b) Herbicide management of invasive cattail (Typha $\times$ glauca $)$ increases porewater nutrient concentrations. Wetlands Ecology and Management 24:457-467

Lawrence BA, Lishawa SC, Hurst N, Castillo BT, Tuchman NC (2017) Wetland invasion by Typha $\times$ glauca increases soil methane emissions. Aquatic Botany 137:80-87

Leck MA, Simpson RL (1987) Seed bank of a freshwater tidal wetland: turnover and relationship to vegetation change. American Journal of Botany 74:360-370

Leck MA, Simpson RL (1993) Seeds and seedlings of the Hamilton marshes, a Delaware River tidal freshwater wetland. Proceedings of the Academy of Natural Sciences of Philadelphia 144:267-281

Lee DE, Conran JG, Lindqvist JK, Bannister JM, Mildenhall DC (2012) New Zealand Eocene, Oligocene and Miocene macrofossil and pollen records and modern plant distributions in the southern hemisphere. The Botanical Review 78:235-260

Leitch JA, Linz GM, Baltezore JF (1997) Economics of cattail (Typha spp.) control to reduce blackbird damage to sunflower. Agriculture, Ecosystems \& Environment 65:141-149

Leto C, Tuttolomondo T, La Bella S, Leone R, Licata M (2013) Effects of plant species in a horizontal subsurface flow constructed wetland phytoremediation of treated urban wastewater with Cyperus alternifolius L. and Typha latifolia L. in the west of Sicily (Italy). Ecological Engineering 61:282-291

Li S, Pezeshki SR, Goodwin S (2004) Effects of soil moisture regimes on photosynthesis and growth in cattail (Typha latifolia). Acta Oecologica 25:17-22

Li S, Mendelssohn IA, Chen H, Orem WH (2009) Does sulphate enrichment promote the expansion of Typha domingensis (cattail) in the Florida Everglades?1. Freshwater Biology 54:1909-1923

Li S, Lissner J, Mendelssohn IA, Brix H, Lorenzen B, McKee KL, Miao S (2010) Nutrient and growth responses of cattail (Typha domingensis) to redox intensity and phosphate availability. Annals of Botany 105:175-184

Liao C, Peng R, Luo Y, Zhou X, Wu X, Fang C, Chen J, Li B (2008) Altered ecosystem carbon and nitrogen cycles by plant invasion: a meta-analysis. New Phytologist 177:706-714

Lichvar RW, Banks DL, Kirchner WN, Melvin NC (2016) The national wetland plant list: 2016 wetland ratings. Phytoneuron 2016-30:117. ISSN $21532733 \mathrm{X}$

Light SS, Dineen JW (1994) Water control in the Everglades: a historical perspective. In: Davis SM, Ogden JC (eds) Everglades: the ecosystem and its restoration. St. Lucie Press, Delray Beach, pp 47-84

Linde AF, Janisch T, Smith D (1976) Cattail-The significance of its growth, phenology and carbohydrate storage to its control and management. Wisconsin Department of Natural Resources Technical Bulletin No. 94

Linz GM (ed) (1992) Proceedings of the cattail management symposium, Fargo, ND. Available via USDA. https://www.aphis.usda.gov/ wildlife damage/nwrc/publications/92pubs/92-72.pdf. Accessed 1 Sept 2018

Linz GM, Blixt DC (1997) Black terns benefit from cattail management in the northern Great Plains. Colonial Waterbirds:617-621

Linz GM, Homan HJ (2011) Use of glyphosate for managing invasive cattail (Typha spp.) to disperse blackbird (Icteridae) roosts. Crop Protection 30:98-104

Linz GM, Klug PE (2017) Strategies for evading blackbird damage. In: Linz GM, Avery ML, Dolbeer RA (eds) Ecology and Management of Blackbirds (Icteridae) in North America. CRC Press, Boca Raton, pp 175-189

Linz GM, Bergman DL, Homan HJ, Bleier WJ (1995) Effects of herbicide-induced habitat alterations on blackbird damage to sunflower. Crop Protection 14:625-629

Linz GM, Blixt DC, Bergman DL, Bleier WJ (1996a) Responses of redwinged blackbirds, yellow-headed blackbirds and marsh wrens to glyphosate-induced alterations in cattail density. Journal of Field Ornithology 67:167-176

Linz GM, Blixt DC, Bergman DL, Bleier WJ (1996b) Response of ducks to glyphosate-induced habitat alterations in wetlands. Wetlands 16 : 38-44

Linz GM, Bergman DL, Blixt DC, McMurl C (1997) Response of american coots and soras to herbicide-induced vegetation changes in wetlands. Journal of Field Ornithology:450-457

Linz GM, Homan HJ, Werner SJ, Hagy HM, Bleier WJ (2011) Assessment of bird-management strategies to protect sunflowers. BioScience 61:960-970

Lishawa SC, Albert DA, Tuchman NC (2010) Water level decline promotes Typha $\times$ glauca establishment and vegetation change in Great Lakes coastal wetlands. Wetlands 30:1085-1096

Lishawa SC, Treering DJ, Vail LM, McKenna O, Grimm EC, Tuchman NC (2013) Reconstructing plant invasions using historical aerial imagery and pollen core analysis: Typha in the Laurentian Great Lakes. Diversity and Distributions 19:14-28

Lishawa SC, Jankowski K, Geddes P, Larkin DJ, Monks AM, Tuchman NC (2014) Denitrification in a Laurentian Great Lakes coastal wetland invaded by hybrid cattail (Typha $\times$ glauca). Aquatic Sciences 76:483-495

Lishawa SC, Lawrence BA, Albert DA, Tuchman NC (2015) Biomass harvest of invasive Typha promotes plant diversity in a Great Lakes coastal wetland. Restoration Ecology 23:228-237

Lishawa SC, Carson BD, Brandt JS, Tallant JM, Reo NJ, Albert DA, Monks AM, Lautenbach JM, Clark E (2017) Mechanical harvesting effectively controls young Typha spp. invasion and unmanned aerial vehicle data enhances post-treatment monitoring. Frontiers in Plant Science 8

Lominchar MA, Sierra MJ, Millán R (2015) Accumulation of mercury in Typha domingensis under field conditions. Chemosphere 119:994999 
Lorenzen B, Brix H, McKee KL, Mendelssohn IA, Miao S (2000) Seed germination of two Everglades species, Cladium jamaicense and Typha domingensis. Aquatic Botany 66:169-180

Lorenzen B, Brix H, Mendelssohn IA, McKee KL, Miao SL (2001) Growth, biomass allocation and nutrient use efficiency in Cladium jamaicense and Typha domingensis as affected by phosphorus and oxygen availability. Aquatic Botany 70:117-133

Low JB (1945) Ecology and management of the redhead, Nyroca americana, in Iowa. Ecological Monographs 15:35-69

Luscz EC, Kendall AD, Hyndman DW (2015) High resolution spatially explicit nutrient source models for the lower peninsula of Michigan. Journal of Great Lakes Research 41:618-629

Lyubenova L, Pongrac P, Vogel-Mikuš K, Mezek GK, Vavpetič P, Grlj N, Regvar M, Pelicon P, Schröder P (2013) The fate of arsenic, cadmium and lead in Typha latifolia: a case study on the applicability of micro-PIXE in plant ionomics. Journal of Hazardous Materials 248249:371-378

Mack GD, Flake LD (1980) Habitat relationships of waterfowl broods on South Dakota stock ponds. The Journal of Wildlife Management 44: 695-700

Maddison M, Soosaar K, Mauring T, Mander Ü (2009) The biomass and nutrient and heavy metal content of cattails and reeds in wastewater treatment wetlands for the production of construction material in Estonia. Desalination 246:120-128

Mahajan G, Chauhan BS, Kumar V (2014) Integrated weed management in rice. In: Chauhan BS, Mahajan G (eds) Recent advances in weed management. Springer, New York, pp 125-153

Mallik AU, Wein RW (1986) Response of a Typha marsh community to draining, flooding, and seasonal burning. Canadian Journal of Botany 64:2136-2143

Manios T, Stentiford EI, Millner PA (2003) The effect of heavy metals accumulation on the chlorophyll concentration of Typha latifolia plants, growing in a substrate containing sewage sludge compost and watered with metaliferus water. Ecological Engineering 20: $65-74$

Marburger JE (2013) Use of pollen to identify cattail (Typha spp., Typhaceae) in Indiana. Plant Science Bulletin 59:174-178

Marburger J, Travis S (2013) Cattail hybridization in national parks: An example of cryptic plant invasions. Park Science 30:58-68

Marchand L, Mench M, Jacob DL, Otte ML (2010) Metal and metalloid removal in constructed wetlands, with emphasis on the importance of plants and standardized measurements: a review. Environmental Pollution 158:3447-3461

Martin DB, Hartman WA (1987) The effect of cultivation on sediment composition and deposition in prairie pothole wetlands. Water, Air, and Soil Pollution 34:45-53

Martina JP, Hamilton SK, Turetsky MR, Phillippo CJ (2014) Organic matter stocks increase with degree of invasion in temperate inland wetlands. Plant and Soil 385:107-123

Matthews JW, Spyreas G (2010) Convergence and divergence in plant community trajectories as a framework for monitoring wetland restoration progress. Journal of Applied Ecology 47:1128-1136

Matthews JW, Spyreas G, Endress AG (2009) Trajectories of vegetationbased indicators used to assess wetland restoration progress. Ecological Applications 19:2093-2107

Mbuligwe SE (2004) Comparative effectiveness of engineered wetland systems in the treatment of anaerobically pre-treated domestic wastewater. Ecological Engineering 23:269-284

McCauley LA, Anteau MJ (2014) Generating nested wetland catchments with readily-available digital elevation data may improve evaluations of land-use change on wetlands. Wetlands 34:1123-1132

McCauley LA, Anteau MJ, van der Burg MP, Wiltermuth MT (2015) Land use and wetland drainage affect water levels and dynamics of remaining wetlands. Ecosphere 6:art92

McCormick PV, Shuford RBE III, Backus JG, Kennedy WC (1997) Spatial and seasonal patterns of periphyton biomass and productivity in the northern Everglades, Florida, U.S.a. Hydrobiologia 362:185-210

McCormick PV, Newman S, Miao SL, Gawlik DE, Marley D, Reddy KR, Fontaine TD (2002) Effects of anthropogenic phosphorus inputs on the Everglades. In: Porter JW, Porter KG (eds) The Everglades, Florida bay, and coral reefs of the Florida keys: An ecosystem sourcebook. CRC Press, Boca Raton, pp 83-126

McCormick PV, Shuford RBE, Rawlik PS (2004) Changes in macroinvertebrate community structure and function along a phosphorus gradient in the Florida Everglades. Hydrobiologia 529:113-132

McCormick PV, Newman S, Vilchek LW (2009) Landscape responses to wetland eutrophication: loss of slough habitat in the Florida Everglades, USA. Hydrobiologia 621:105-114

McDonald ME (1955) Cause and effects of a die-off of emergent vegetation. The Journal of Wildlife Management 19:24-35

McInerney E, Helton AM (2016) The effects of soil moisture and emergent herbaceous vegetation on carbon emissions from constructed wetlands. Wetlands 36:275-284

McKee KL, Mendelssohn IA, Burdick DM (1989) Effect of long-term flooding on root metabolic response in five freshwater marsh plant species. Canadian Journal of Botany 67:3446-3452

McKenna OP, Mushet DM, Rosenberry DO, LaBaugh JW (2017) Evidence for a climate-induced ecohydrological state shift in wetland ecosystems of the southern prairie pothole region. Climatic Change 145:273-287

McKenzie-Gopsill A, Kirk H, Van Drunen W, Freeland JR, Dorken ME (2012) No evidence for niche segregation in a north American cattail (Typha) species complex. Ecology and Evolution 2:952-961

McNaughton SJ (1968) Autotoxic feedback in relatin to germination and seedling growth in Typha latifolia. Ecology 49:367-369

Meanley B (1965) The roosting behavior of the red-winged black-bird in the southern United States. The Wilson Bulletin 77:217-228

Meese R (2006) Settlement and breeding colony characteristics of tricolored blackbirds in 2006 in the Central Valley of California. Available via ResearchGate https://www.researchgate.net/profile/ Robert_Meese/publication/266866246_Settlement_and_Breeding Colony_Characteristics_of_Tricolored_Blackbirds_in_2006_in the_Central_Valley_of_California/links $/ 5492 \mathrm{df} 3 \mathrm{c} 0 \mathrm{c}$ $\mathrm{f} 209 \mathrm{fc} 7 \mathrm{e} 9 \mathrm{f} 83 \mathrm{~b} \overline{\mathrm{f}} /$ Settlement-and-Breeding-Colony-Characteristicsof-Tricolored-Blackbirds-in-2006-in-the-Central-Valley-ofCalifornia.pdf?origin=publication_detail. Accessed 1 Sept 2018

Melillo JM, Richmond TC, Yohe GW (eds) (2014) Climate change impacts in the United States: the third national climate assessment. U.S. Global Change Research Program, Washington, D.C.

Messersmith CG, Christianson KM, Thorsness KB (1992) Influence of glyphosate rate, application date, and spray volume on cattail control. North Dakota Farm Research 49:27-28

Meyer SW (2003) Comparative use of Phragmites australis and other habitats by birds, amphibians, and small mammals at Long Point, Ontario. Dissertation, University of Western Ontario

Miao S (2004) Rhizome growth and nutrient resorption: mechanisms underlying the replacement of two clonal species in Florida Everglades. Aquatic Botany 78:55-66

Miao SL, DeBusk WF (1999) Effects of phosphorus enrichment on structure and function of sawgrass and cattail communities in the Everglades. In: Reddy KR, O'Connor GA, Schelske CL (eds) Phosphorus biogeochemistry in sub-tropical ecosystems. Lewis Publishers, Boca Raton, pp 275-299

Miao SL, Sklar FH (1998) Biomass and nutrient allocation of sawgrass and cattail along a nutrient gradient in the Florida Everglades. Wetlands Ecology and Management 5:245-264

Miao SL, McCormick PV, Newman S, Rajagopalan S (2001) Interactive effects of seed availability, water depth, and phosphorus enrichment on cattail colonization in an Everglades wetland. Wetlands Ecology and Management 9:39-47 
Mifsud DA (2014) A status assessment and review of the herpetofauna within the Saginaw Bay of Lake Huron. Journal of Great Lakes Research 40:183-191

Miller J (1882) CM catalog number CM169653

Miller RL, Fujii R (2010) Plant community, primary productivity, and environmental conditions following wetland re-establishment in the Sacramento-san Joaquin Delta, California. Wetlands Ecology and Management 18:1-16

Minc LD (1997) Great Lakes coastal wetlands: An overview of controlling abiotic factors, regional distribution, and species composition. Available via MNFI http://mnfi.anr.msu.edu/reports/1997-13.pdf. Accessed 1 Sept 2018

Minnesota Department of Natural Resources (2008) Natural wild rice in Minnesota. Available via MNDNR http://files.dnr.state.mn.us/fish wildlife/wildlife/shallowlakes/natural-wild-rice-in-minnesota.pdf. Accessed 1 Sept 2018

Mitchell ME, Lishawa SC, Geddes P, Larkin DJ, Treering D, Tuchman NC (2011) Time-dependent impacts of cattail invasion in a Great Lakes coastal wetland complex. Wetlands 31:1143-1149

Mitich LM (2000) Common cattail, Typha latifolia L. Weed Technology $14: 446-450$

Mitsch WJ (1992) Combining ecosystem and landscape approaches to Great Lakes wetlands. Journal of Great Lakes Research 18:552-570

Mojiri A, Aziz HA, Zahed MA, Aziz SQ, Selamat MRB (2013) Phytoremediation of heavy metals from urban waste leachate by southern cattail (Typha domingensis). International Journal of Scientific Research in Environmental Sciences 1:63-70

Morteau B, Triffault-Bouchet G, Galvez R, Martel L (2015) Nutrient and removal kinetics impacts on salt phytoremediation by Atriplex patula and Typha angustifolia. Journal of Environmental Engineering 141:04014059

Morton JF (1975) Cattails (Typha spp.) — weed problem or potential crop? Economic Botany 29:7-29

Moustafa MZ, White JR, Coghlan CC, Reddy KR (2011) Influence of hydropattern and vegetation type on phosphorus dynamics in flowthrough wetland treatment systems. Ecological Engineering 37: $1369-1378$

Muenscher WC (1955) Weeds, 2nd edn. Edn. The Macmillan company, New York

Mufarrege MM, Hadad HR, Di Luca GA, Maine MA (2014) Metal dynamics and tolerance of Typha domingensis exposed to high concentrations of $\mathrm{Cr}$, Ni and Zn. Ecotoxicology and Environmental Safety 105:90-96

Murkin HR, Ward P (1980) Early spring cutting to control cattail in a northern marsh. Wildlife Society Bulletin 8:254-256

Mushet DM, Calhoun AJK, Alexander LC, Cohen MJ, DeKeyser ES, Fowler L, Lane CR, Lang MW, Rains MC, Walls SC (2015a) Geographically isolated wetlands: rethinking a misnomer. Wetlands 35:423-431

Mushet DM, Goldhaber MB, Mills CT, McLean KI, Aparicio VM, McCleskey RB, Holloway JM, Stockwell CA (2015b) Chemical and biotic characteristics of prairie lakes and large wetlands in south-central North Dakota - Effects of a changing climate. U.S. Geological Survey Scientific Investigations Report 2015-5126

Nelson NF, Dietz RH (1966) Typha control methods in Utah. Utah State Department of Fish and Game Publication No. 66-2

Nelson JW, Kadlec JA, Murkin HR (1990a) Seasonal comparisons of weight loss for two types of Typha glauca Godr. Leaf litter. Aquatic Botany 37:299-314

Nelson JW, Kadlec JA, Murkin HR (1990b) Responses by macroinvertebrates to cattail litter quality and timing of litter submergence in a northern prairie marsh. Wetlands 10:47-60

Neve P, Powles SW (2005) High survival frequencies at low herbicide use rates in populations of Lolium rigidum result in rapid evolution of herbicide resistance. Heredity 95:485-492
Newman S, Pietro K (2001) Phosphorus storage and release in response to flooding: implications for Everglades stormwater treatment areas. Ecological Engineering 18:23-38

Newman S, Grace JB, Koebel JW (1996) Effects of nutrients and hydroperiod on Typha, Cladium, and Eleocharis: implications for Everglades restoration. Ecological Applications 6:774-783

Newman S, Schuette J, Grace JB, Rutchey K, Fontaine T, Reddy KR, Pietrucha M (1998) Factors influencing cattail abundance in the northern Everglades. Aquatic Botany 60:265-280

Newman S, Manna M, Cook M (2017) Cattail habitat improvement project. In: Sklar F and Dreschel T (eds) Chapter 6: Everglades research and evaluation. South Florida Water Management District, 2017 South Florida Environmental Report - Volume I, West Palm Beach, FL, pp 40-45

Newman S, Manna M, Cook M, Zweig C, Rodgers L, Mason C, Pollack K (2018) Active marsh improvement projects. In: Sklar F and Dreschel T (eds) Chapter 6: Everglades research and evaluation. South Florida Water Management District, 2018 South Florida Environmental Report - Volume I, West Palm Beach, FL, pp 48-54

Noe GB, Childers DL (2007) Phosphorus budgets in Everglades wetland ecosystems: the effects of hydrology and nutrient enrichment. Wetlands Ecology and Management 15:189-205

Noe GB, Childers DL, Jones RD (2001) Phosphorus biogeochemistry and the impact of phosphorus enrichment: why is the Everglades so unique? Ecosystems 4:603-624

Norsworthy JK, Ward SM, Shaw DR, Llewellyn RS, Nichols RL, Webster TM, Bradley KW, Frisvold G, Powles SB, Burgos NR, Witt WW, Barrett M (2012) Reducing the risks of herbicide resistance: best management practices and recommendations. Weed Science 60:31-62

Ollerton J, Winfree R, Tarrant S (2011) How many flowering plants are pollinated by animals? Oikos 120:321-326

Olson MH, Carpenter SR, Cunningham P, Gafny S, Herwig BR, Nibbelink NP, Pellett T, Storlie C, Trebitz AS, Wilson KA (1998) Managing macrophytes to improve fish growth: a multi-lake experiment. Fisheries 23:6-12

Olson A, Paul J, Freeland JR (2009) Habitat preferences of cattail species and hybrids (Typha spp.) in eastern Canada. Aquatic Botany 91:6770

Osland MJ, González E, Richardson CJ (2011) Restoring diversity after cattail expansion: disturbance, resilience, and seasonality in a tropical dry wetland. Ecological Applications 21:715-728

Otis CH (1914) The transpiration of emersed water plants: its measurement and its relationships. Botanical Gazette 58:457-494

Otto CRV, Roth CL, Carlson BL, Smart MD (2016) Land-use change reduces habitat suitability for supporting managed honey bee colonies in the northern Great Plains. Proceedings of the National Academy of Sciences 113:10430-10435

Pandey VC, Singh N, Singh RP, Singh DP (2014) Rhizoremediation potential of spontaneously grown Typha latifolia on fly ash basins: study from the field. Ecological Engineering 71:722-727

Payne NF (1998) Wildlife habitat management of wetlands. Krieger Publishing Company, Malabar

Peer BD, Abernathy VE (2017) The brown-headed cowbird: ecology and management of an avian brood parasite. In: Linz GM, Avery ML, Dolbeer RA (eds) Ecology and Management of Blackbirds (Icteridae) in North America. CRC Press, Boca Raton, pp 77-99

Peer BD, Homan HJ, Linz GM, Bleier WJ (2003) Impact of blackbird damage to sunflower: bioenergetic and economic models. Ecological Applications 13:248-256

Perez A, Mazerolle MJ, Brisson J (2013) Effects of exotic common reed (Phragmites australis) on wood frog (Lithobates sylvaticus) tadpole development and food availability. Journal of Freshwater Ecology 28:165-177

Perry LG, Galatowitsch SM, Rosen CJ (2004) Competitive control of invasive vegetation: a native wetland sedge suppresses Phalaris 
arundinacea in carbon-enriched soil. Journal of Applied Ecology 41:151-162

Pezeshki SR, DeLaune RD, Kludze HK, Choi HS (1996) Photosynthetic and growth responses of cattail (Typha domingensis) and sawgrass (Cladium jamaicense) to soil redox conditions. Aquatic Botany 54: $25-35$

Pfukenyi DM, Monrad J, Mukaratirwa S (2005) Epidemiology and control of trematode infections in cattle in Zimbabwe : a review : review article. Journal of the South African Veterinary Association 76:9-17

Pieper SJ, Nicholls AA, Freeland JR, Dorken ME (2017) Asymmetric hybridization in cattails (Typha spp.) and its implications for the evolutionary maintenance of native Typha latifolia. Journal of Heredity 108:479-487

Pieper SJ, Freeland JR, Dorken ME (2018) Coexistence of Typha latifolia, T. angustifolia (Typhaceae) and their invasive hybrid is not explained by niche partitioning across water depths. Aquatic Botany 144:46-53

Pietro KC, Ivanoff D (2015) Comparison of long-term phosphorus removal performance of two large-scale constructed wetlands in South Florida, U.S.a. Ecological Engineering 79:143-157

Pillsbury RW, McGuire MA (2009) Factors affecting the distribution of wild rice (Zizania palustris) and the associated macrophyte community. Wetlands 29:724

Ponzio KJ, Miller SJ, Lee MA (2004) Long-term effects of prescribed fire on Cladium jamaicense crantz and Typha domingensis pers. densities. Wetlands Ecology and Management 12:123-133

Pope K, Masuoka P, Rejmankova E, Grieco J, Johnson S, Roberts D (2005) Mosquito habitats, land use, and malaria risk in Belize from satellite imagery. Ecological Applications 15:1223-1232

Post van der Burg M, Jenni KE, Nieman TL, Eash JD, Knutsen GA (2014) Decision analysis of mitigation and remediation of sedimentation within large wetland systems - A case study using Agassiz National Wildlife Refuge. U.S. Geological Survey Open-File Report 2014-1180

Post van der Burg M, Anteau MJ, McCauley LA, Wiltermuth MT (2016) A Bayesian approach for temporally scaling climate for modeling ecological systems. Ecology and Evolution 6:2978-2987

Rahman QM, Wang L, Zhang B, Xiu S, Shahbazi A (2015) Green biorefinery of fresh cattail for microalgal culture and ethanol production. Bioresource Technology 185:436-440

Ralston ST, Linz GM, Bleier WJ, Homan HJ (2007) Cattail distribution and abundance in North Dakota. Journal of Aquatic Plant Management 45:21-24

Raven GH, Armstrong LM, Howerter DW, Arnold TW (2007) Wetland selection by mallard broods in Canada's prairie-parklands. The Journal of Wildlife Management 71:2527-2531

Rebaque D, Martinez-Rubio R, Fornale S, Garcia-Angulo P, AlonsoSimon A, Alvarez JM, Caparros-Ruiz D, Acebes JL, Encina A (2017) Characterization of structural cell wall polysaccharides in cattail (Typha latifolia): evaluation as potential biofuel feedstock. Carbohydrate Polymers 175:679-688

Reddy KR, Delaune RD, Debusk WF, Koch MS (1993) Long-term nutrient accumulation rates in the Everglades. Soil Science Society of America Journal 57:1147-1155

Rehm EM, Baldassarre GA (2007) The influence of interspersion on marsh bird abundance in New York. The Wilson Journal of Ornithology 119:648-654

Rejmánková E (2001) Effect of experimental phosphorus enrichment on oligotrophic tropical marshes in Belize. Central America. Plant and Soil 236:33-53

Renton DA, Mushet DM, DeKeyser ES (2015) Climate change and prairie pothole wetlands: Mitigating water-level and hydroperiod effects through upland management. U.S Geological Survey Scientific Investigations Report 2015-5004
Reo NJ, Ogden LA (2018) Anishnaabe Aki: an indigenous perspective on the global threat of invasive species. Sustainability Science 13: $1443-1452$

Rhymer JM, Simberloff D (1996) Extinction by hybridization and introgression. Annual Review of Ecology and Systematics 27:83-109

Richardson CJ (2008) The Everglades experiments: lessons for ecosystem restoration. Springer-Verlag, New York

Richardson CJ, King RS, Vymazal J, Romanowicz EA, Pahl JW (2008a) Macrophyte community responses in the Everglades with an emphasis on cattail (Typha domingensis) and sawgrass (Cladium jamaicense) interactions along a gradient of long-term nutrient additions, altered hydroperiod, and fire. In: Richardson CJ (ed) The Everglades experiments: lessons for ecosystem restoration. Springer-Verlag, New York, pp 215-260

Richardson CJ, Pahl JW, Vymazal J, Vaithiyanathan P, Qualls RG, Sundareshwar PV, Barber ML, Johnson J (2008b) Enrichment gradients in WCA-2A and northern WCA-3A: water, soil, plant biomass, and nutrient storage responses. In: Richardson CJ (ed) The Everglades experiments: lessons for ecosystem restoration. Springer-Verlag, New York, pp 103-165

Ringim AS, Sabo BB, Harry H (2015) Implication of invasive plant Typha domingensis on biodiversity: An ecological study of the Hadejia-Nguru wetlands, Nigeria. Scholarly Journal of Biological Science 4:40-46

Rippke MB, Distler MT, Farrell JM (2010) Holocene vegetation dynamics of an upper St. Lawrence River wetland: Paleoecological evidence for a recent increase in cattail (Typha). Wetlands 30:805-816

Rodenburg J, Johnson DE (2013) Managing weeds of rice in Africa. In: Wopereis MCS, Johnson DE, Ahmadi N, Tollens E, Jalloh A (eds) Realizing Africa's rice promise. CABI, Wallingford, pp 204-212

Rodgers L, Black D (2012) Effects of aerially-applied imazamox on southern cattail and non-target emergent vegetation in a eutrophic sawgrass marsh. Journal of Aquatic Plant Management 50:125-129

Rose C, Crumpton WG (1996) Effects of emergent macrophytes on dissolved oxygen dynamics in a prairie pothole wetland. Wetlands 16: 495-502

Russell KR, Van Lear DH, Guynn DC (1999) Prescribed fire effects on herpetofauna: review and management implications. Wildlife Society Bulletin 27:374-384

Rutchey K, Vilchek L (1999) Air photointerpretation and satellite imagery analysis techniques for mapping cattail coverage in a northern Everglades impoundment. Photogrammetric Engineering and Remote Sensing 65:185-191

Rutchey K, Vilchek L, Love M (2005) Development of a vegetation map for Water Conservation Area 3. South Florida Water Management District Technical Publication ERA \#421

Rutchey K, Schall T, Sklar F (2008) Development of vegetation maps for assessing Everglades restoration progress. Wetlands 28:806-816

Sabo BB, Karaye AK, Garba A, Ja'afar U (2016) Typha grass militating against agricultural productivity along Hadejia River, Jigawa state, Nigeria. Scholarly Journal of Agricultural Science 6:52-56

Safratowich B, Linz GM, Bleier WH, Homan HJ (2008) Avian use of rural roadsides with cattail (Typha spp.). The American Midland Naturalist 159:162-171

Salako G, Sawyerr H, Olalubi O (2016) Does Typha spp. contribute to wetland waterloss and health risk: a case study of Hadejia Nguru wetlands (HNW) system NE Nigeria. Open Journal of Ecology 6: $151-158$

Sale PJM, Wetzel RG (1983) Growth and metabolism of Typha species in relation to cutting treatments. Aquatic Botany 15:321-334

Schimming W, K., Thorsness KB, Hickman MV, Messersmith CG, Lym RG (1987) Typha (Typha spp.) control with herbicides. Proceedings of the western society of Weed Science 40:20

Schmidt JO, Thoenes SC, Levin MD (1987) Survival of honey bees, Apis mellifera (Hymenoptera: Apidae), fed various pollen sources. Annals of the Entomological Society of America 80:176-183 
Schmidt JO, Buchmann SL, Glaum M (1989) The nutritional value of Typha latifolia pollen for bees. Journal of Apicultural Research 28: 155-165

Schultz BD (1987) Biotic responses on Typha-monodominant semipermanent wetlands to cattle grazing. Thesis, South Dakota State University

Schummer ML, Palframan J, McNaughton E, Barney T, Petrie SA (2012) Comparisons of bird, aquatic macroinvertebrate, and plant communities among dredged ponds and natural wetland habitats at long point, Lake Erie, Ontario. Wetlands 32:945-953

Seabloom EW, Moloney KA, van der Valk AG (2001) Constraints on the establishment of plants along a fluctuating water-depth gradient. Ecology 82:2216-2232

Sebacher DI, Harriss RC, Bartlett KB (1985) Methane emissions to the atmosphere through aquatic plants. Journal of Environmental Quality 14:40-46

Shay JM, de Geus PMJ, Kapinga MRM (1999) Changes in shoreline vegetation over a 50-year period in the Delta Marsh, Manitoba in response to water levels. Wetlands 19:413-425

Shih JG, Finkelstein SA (2008) Range dynamics and invasive tendencies in Typha latifolia and Typha angustifolia in eastern North America derived from herbarium and pollen records. Wetlands 28:1-16

Shwiff SA, Ernest KL, Degroot SL, Anderson AM, Shwiff SS (2017) The economic impact of blackbird damage to crops. In: Linz GM, Avery ML, Dolbeer RA (eds) Ecology and Management of Blackbirds (Icteridae) in North America. CRC Press, Boca Raton, pp 207-216

Sifton HB (1959) The germination of light-sensitive seeds of Typha latifolia L. Canadian Journal of Botany 37:719-739

Silliman BR, Mozdzer T, Angelini C, Brundage JE, Esselink P, Bakker JP, Gedan KB, van de Koppel J, Baldwin AH (2014) Livestock as a potential biological control agent for an invasive wetland plant. PeerJ 2:e567

Sklar FH, Chimney MJ, Newman S, McCormick P, Gawlik D, Miao S, McVoy C, Said W, Newman J, Coronado C, Crozier G, Korvela M, Rutchey K (2005) The ecological-societal underpinnings of Everglades restoration. Frontiers in Ecology and the Environment 3:161-169

Sklar F, Dreschel T, Warren K (2009) Chapter 6: Ecology of the Everglades Protection Area, South Florida Environmental Report. Available via SFWMD http://my.sfwmd.gov/portal/page/portal/pg grp_sfwmd_sfer/portlet_sfer/tab2236041/2009report/report/v1/ chapters/v1 ch6.pdf. Accessed 25 Oct 2018

Sklar F, Dreschel T, Warren K (2011) Chapter 6: Ecology of the Everglades Protection Area, South Florida Environmental Report. Available via SFWMD http://my.sfwmd.gov/portal/page/portal/pg grp_sfwmd_sfer/portlet_prevreport/2011_sfer/v1/chapters/v1_ch6. pdf. Accessed 25 Oct 2018

Smart MD, Cornman RS, Iwanowicz DD, McDermott-Kubeczko M, Pettis JS, Spivak MS, Otto CRV (2017) A comparison of honey bee-collected pollen from working agricultural lands using light microscopy and ITS metabarcoding. Environmental Entomology 46: $38-49$

Smith SG (1967) Experimental and natural hybrids in north American Typha (Typhaceae). The American Midland Naturalist 78:257-287

Smith SG (1987) Typha: its taxonomy and the ecological significance of hybrids. Archiv für Hydrobiologie 27:129-138

Smith LM (1988) Lack of vertebrate herbivory in playa wetlands. Wetlands 8:193-197

Smith SG (2000) Typhaceae. In: Flora of North America Editorial Committee (eds.) Flora of North America North of Mexico, Vol 22. Oxford University Press, New York, pp 278-285

Smith RJ, Jr., Flinchum WT, Seaman DE (1977) Weed control in US rice production. U.S. Department of Agriculture Handbook No. 497

Smith LM, Kadlec JA (1985) Comparisons of prescribed burning and cutting of Utah marsh plants. The Great Basin Naturalist 45:462 466
Smith SM, Newman S (2001) Growth of southern cattail (Typha domingensis Pers.) seedlings in response to fire-related soil transformations in the northern Florida everglades. Wetlands 21:363-369

Smith SM, Newman S, Garrett PB, Leeds JA (2001) Differential effects of surface and peat fire on soil constituents in a degraded wetland of the northern Florida Everglades. Journal of Environmental Quality 30:1998-2005

Smith SM, McCormick PV, Leeds JA, Garrett PB (2002) Constraints of seed bank species composition and water depth for restoring vegetation in the Florida Everglades, U.S.a. Restoration Ecology 10: $138-145$

Smith SM, Gawlik DE, Rutchey K, Crozier GE, Gray S (2003) Assessing drought-related ecological risk in the Florida Everglades. Journal of Environmental Management 68:355-366

Smith C, DeKeyser ES, Dixon C, Kobiela B, Little A (2016) Effects of sediment removal on prairie pothole wetland plant communities in North Dakota. Natural Areas Journal 36:48-58

Smokorowski KE, Pratt TC (2007) Effect of a change in physical structure and cover on fish and fish habitat in freshwater ecosystems - a review and meta-analysis. Environmental Reviews 15:15-41

Snow AA, Travis SE, Wildová R, Fér T, Sweeney PM, Marburger JE, Windels S, Kubátová B, Goldberg DE, Mutegi E (2010) Speciesspecific SSR alleles for studies of hybrid cattails (Typha latifolia $\times$ T. angustifolia; Typhaceae) in North America. American Journal of Botany 97:2061-2067

Sojda RS, Solberg KL (1993) Management and control of cattails. U.S. Fish and Wildlife Service Fish and Wildlife Leaflet 13, 13(4)

Solberg KL, Higgins KF (1993) Effects of glyphosate herbicide on cattails, invertebrates, and waterfowl in South Dakota wetlands. Wildlife Society Bulletin 21:299-307

Sorrell BK, Mendelssohn IA, McKee KL, Woods RA (2000) Ecophysiology of wetland plant roots: a modelling comparison of aeration in relation to species distribution. Annals of Botany 86: 675-685

South Florida Water Management District (2018) Quick facts and figures. Available via SFWMD. https://www.sfwmd.gov/who-we-are/factsand-figures. Accessed 22 Oct 2018

Sritrairat S, Peteet DM, Kenna TC, Sambrotto R, Kurdyla D, Guilderson $\mathrm{T}$ (2012) A history of vegetation, sediment and nutrient dynamics at Tivoli North Bay, Hudson estuary, New York. Estuarine, Coastal and Shelf Science 102-103:24-35

Steenis JH, Smith LP, Cofer HP (1959) Studies on Typha management in the northeast. Transactions of the Northeast Wildlife Conference 10: $149-155$

Steinbachová-Vojtî̌sová L, Tylová E, Soukup A, Novická H, Votrubová O, Lipavská H, Čížková H (2006) Influence of nutrient supply on growth, carbohydrate, and nitrogen metabolic relations in Typha angustifolia. Environmental and Experimental Botany 57:246-257

Stephens JP, Berven KA, Tiegs SD (2013) Anthropogenic changes to leaf litter input affect the fitness of a larval amphibian. Freshwater Biology 58:1631-1646

Stephenson PL (2017) Bee communities on managed emergent wetlands in the lower Mississippi Alluvial Valley of Arkansas. Thesis, University of Arkansas

Steward KK, Ornes WH (1983) Mineral nutrition of sawgrass (Cladium jamaicense Crantz) in relation to nutrient supply. Aquatic Botany 16:349-359

Stewart RE, Kantrud HA (1971) Classification of natural ponds and lakes in the glaciated prairie region. U.S. Fish and Wildlife Service, Bureau of Sport Fisheries and Wildlife Resource Publication 92

Stewart RE, Kantrud HA (1972) Vegetation of prairie potholes, North Dakota, in relation to quality of water and other environmental factors. U.S. Geological Survey Professional Paper:585-58D

Stewart H, Miao SL, Colbert M, Carraher CE (1997) Seed germination of two cattail (Typha) species as a function of Everglandes nutrient levels. Wetlands 17:116-122 
Stottmeister U, Wiessner A, Kuschk P, Kappelmeyer U, Kastner M, Bederski O, Muller RA, Moormann H (2003) Effects of plants and microorganisms in constructed wetlands for wastewater treatment. Biotechnology Advances 22:93-117

Sultana M-Y, Akratos CS, Pavlou S, Vayenas DV (2014) Chromium removal in constructed wetlands: a review. International Biodeterioration \& Biodegradation 96:181-190

Surratt D, Shinde D, Aumen N (2012) Recent cattail expansion and possible relationships to water management: changes in upper Taylor Slough (Everglades National Park, Florida, USA). Environmental Management 49:720-733

Sutton-Grier AE, Megonigal JP (2011) Plant species traits regulate methane production in freshwater wetland soils. Soil Biology and Biochemistry 43:413-420

Svedarsky D, Bruggman J, Ellis-Felege S, Grosshans R, Lane V, Norrgard R, Knutsen G, Clarke R, Ripplinger D, Ostlund A, Lewis J, Granfors J, Brenny T (2016) Cattail management in the Northern Great Plains: Implications for wetland wildlife and bioenergy harvest. Available via UMN https://www.nwroc.umn. edu/sites/nwroc.umn.edu/files/cattail_management.pdf. Accessed 1 Sept 2018

Swanson GA (1992) Cycles of cattails in individual wetlands: environmental influences. In Linz GM (ed) Proceedings of the cattail management symposium, Fargo, ND, pp 13-17. Available via USDA. https://www.aphis.usda.gov/wildlife_damage/nwre/publications/ 92pubs/92-72.pdf. Accessed 1 Sept 2018

Swanson GA, Duebbert HF (1989) Wetland habitats of waterfowl in the prairie pothole region. In: Van der Valk AG (ed) Northern prairie wetlands. Iowa State University Press, Ames, pp 228-267

Swanson GA, Winter TC, Adomaitis VA, LaBaugh JW (1988) Chemical characteristics of prairie lakes in south-central North Dakota - their potential for influencing use by fish and wildlife. U.S. Fish and Wildlife Service Fish and Wildlife Technical Report No. 18

Swanson GA, Euliss Jr NH, Hanson BA, Mushet DM (2003) Dynamics of a prairie pothole wetland complex: implications for wetland management. In: Winter TC (ed) Hydrological, chemical, and biological characteristics of a prairie pothole wetland complex under highly variable climate conditions - the Cottonwood Lake Area, eastcentral North Dakota. US Geological Survey Professional Paper 1675, Denver, CO, pp 55-94

Szabo J, Freeland JR, Dorken ME (2018) The effects of leaf litter and competition from hybrid cattails (Typha $\times$ glauca) on the seed germination and seedling performance of its parental species. Aquatic Botany 145:29-36

Takos MJ (1947) A semi-quantitative study of muskrat food habits. The Journal of Wildlife Management 11:331-339

Tang CF, Liu YG, Zeng GM, Li X, Xu WH, Li CF, Yuan XZ (2005) Effects of exogenous spermidine on antioxidant system responses of Typha latifolia $\mathrm{L}$. under $\mathrm{Cd}^{2+}$ stress. Journal of Integrative Plant Biology 47:428-434

Tangen BA, Finocchiaro RG, Gleason RA (2015) Effects of land use on greenhouse gas fluxes and soil properties of wetland catchments in the prairie pothole region of North America. Science of the Total Environment 533:391-409

Tanko A (2007) Improving land and water resources management in the Komadugu Yobe River Basin - north eastern Nigeria and south eastern Niger. Available via IUCN https://www.iucn.org/ downloads/komadugu_yobe_basin_midterm_feb2007.pdf. Accessed 1 Sept 2018

Tanner DK, Brazner JC, Brady VJ, Regal RR (2004) Habitat associations of larval fish in a Lake Superior coastal wetland. Journal of Great Lakes Research 30:349-359

Thiet RK (2002) Diversity comparisons between diked and undiked coastal freshwater marshes on Lake Erie during a high-water year. Journal of Great Lakes Research 28:285-298
Thompson D, Chartrand D, Staznik B, Leach J, Hodgins P (2010) Integrating advanced technologies for optimization of aerial herbicide applications. New Forests 40:45-66

Tian H, Xu X, Miao S, Sindhoj E, Beltran BJ, Pan Z (2010) Modeling ecosystem responses to prescribed fires in a phosphorus-enriched Everglades wetland: I. phosphorus dynamics and cattail recovery. Ecological Modelling 221:1252-1266

Timmons FL, Bruns VF, Lee WO, Yeo RR, Hodgson JM, Weldon LW, Comes RD (1963) Studies on the control of common cattail in drainage channels and ditches. U.S. Department of Agriculture Technical Bulletin No. 1286

Tonn WM, Magnuson JJ (1982) Patterns in the species composition and richness of fish assemblages in northern Wisconsin lakes. Ecology 63:1149-1166

Tornberg T, Bendix M, Brix H (1994) Internal gas transport in Typha latifolia L. and Typha angustifolia L. 2. Convective throughflow pathways and ecological significance. Aquatic Botany 49:91-105

Torti VM, Dunn PO (2005) Variable effects of climate change on six species of north American birds. Oecologia 145:486-495

Travis SE, Marburger JE, Windels S, Kubátová B (2010) Hybridization dynamics of invasive cattail (Typhaceae) stands in the Western Great Lakes region of North America: a molecular analysis. Journal of Ecology 98:7-16

Travis SE, Marburger JE, Windels SK, Kubátová B (2011) Clonal structure of invasive cattail (Typhaceae) stands in the upper Midwest region of the US. Wetlands 31:221-228

Trebitz AS, Hoffman JC (2015) Coastal wetland support of Great Lakes fisheries: Progress from concept to quantification. Transactions of the American Fisheries Society 144:352-372

Truua J, Truu M, Espenberg M, Nõlvak H, Juhanson J (2015) Phytoremediation and plant-assisted bioremediation in soil and treatment wetlands: a review. The Open Biotechnology Journal 9

Tsyusko-Omeltchenko OV, Schable NA, Smith MH, Glenn TC (2003) Microsatellite loci isolated from narrow-leaved cattail Typha angustifolia. Molecular Ecology Notes 3:535-538

Tu M, Hurd C, Randall JM (2001) Weed control methods handbook: Tools and techniques for use in natural areas. Available via TNC http://www.invasive.org/gist/products/handbook/methodshandbook.pdf. Accessed 1 Sept 2018

Tuchman NC, Larkin DJ, Geddes P, Wildova R, Jankowski K, Goldberg DE (2009) Patterns of environmental change associated with Typha x glauca invasion in a Great Lakes coastal wetland. Wetlands 29: 964-975

Tulbure MG, Johnston CA, Auger DL (2007) Rapid invasion of a Great Lakes coastal wetland by non-native Phragmites australis and Typha. Journal of Great Lakes Research 33:269-279

Turner AM, Trexler JC, Jordan CF, Slack SJ, Geddes P, Chick JH, Loftus WF (1999) Targeting ecosystem features for conservation: standing crops in the Florida Everglades. Conservation Biology 13:898-911

Tursun N, Seyithanoglu M, Uygur FN, Elibuyuk IO, Elibuyuk EA (2011) Seasonal dynamics of soluble carbohydrates in rhizomes of Phragmites australis and Typha latifolia. Flora - Morphology, Distribution, Functional Ecology of Plants 206:731-735

Umbach LM (1895) WIS catalog number v0322369WIS

Updegraff K, Bridgham SD, Pastor J, Weishampel P, Harth C (2001) Response of $\mathrm{CO}_{2}$ and $\mathrm{CH}_{4}$ emissions from peatlands to warming and water table manipulation. Ecological Applications 11:311-326

Urban NH, Davis SM, Aumen NG (1993) Fluctuations in sawgrass and cattail densities in Everglades water conservation area 2A under varying nutrient, hydrologic and fire regimes. Aquatic Botany 46: 203-223

Vaccaro LE, Bedford BL, Johnston CA (2009) Litter accumulation promotes dominance of invasive species of cattails (Typha spp.) in Lake Ontario wetlands. Wetlands 29:1036-1048 
Vaithiyanathan P, Richardson CJ (1999) Macrophyte species changes in the Everglades: examination along a eutrophication gradient. Journal of Environmental Quality 28:1347-1358

van der Kamp G, Hayashi M, Gallén D (2003) Comparing the hydrology of grassed and cultivated catchments in the semi-arid Canadian prairies. Hydrological Processes 17:559-575

van der Valk AG (1994) Effects of prolonged flooding on the distribution and biomass of emergent species along a freshwater wetland coenocline. Vegetatio 110:185-196

van der Valk AG (2005) Water-level fluctuations in north American prairie wetlands. Hydrobiologia 539:171-188

van der Valk AG, Baalman MA (2018) Effects of seed treatments, delayed planting and groundwater levels on the restoration of sedge meadows. Wetlands 38:875-883

van der Valk AG, Davis CB (1978) The role of seed banks in the vegetation dynamics of prairie glacial marshes. Ecology 59:322-335

van der Valk AG, Davis CB (1980) The impact of a natural drawdown on the growth of four emergent species in a prairie glacial marsh. Aquatic Botany 9:301-322

Varnell CJ, Thawaba SA, Solis M (2010) Typha domingenius-a potential tool for bioremediation of wetlands as relevant to environmental forensics: a case study from Palo Verde, Costa Rica. Environmental Forensics 11:102-107

Vilà M, Espinar JL, Hejda M, Hulme PE, Jarošík V, Maron JL, Pergl J, Schaffner U, Sun Y, Pyšek P (2011) Ecological impacts of invasive alien plants: a meta-analysis of their effects on species, communities and ecosystems. Ecology Letters 14:702-708

Vymazal J (2013) Emergent plants used in free water surface constructed wetlands: a review. Ecological Engineering 61:582-592

Vymazal J (2014) Constructed wetlands for treatment of industrial wastewaters: a review. Ecological Engineering 73:724-751

Vymazal J, Richardson CJ (2003) The relationship between soil, water nutrients and biomass of Cladium jamaicense and Typha latifolia in the northern Everglades. In: Vymazal J (ed) Nutrients in natural and constructed wetlands. Backhuys Publishers, Leiden

Wang S-C, Jurik TW, van der Valk AG (1994) Effects of sediment load on various stages in the life and death of cattail (Typha $\times$ glauca). Wetlands 14:166-173

Wang Y-C, Ko C-H, Chang F-C, Chen P-Y, Liu T-F, Sheu Y-S, Shih T-L, Teng C-J (2011) Bioenergy production potential for aboveground biomass from a subtropical constructed wetland. Biomass and Bioenergy 35:50-58

Waters I, Shay JM (1990) A field study of the morphometric response of Typha glauca shoots to a water depth gradient. Canadian Journal of Botany 68:2339-2343

Waters I, Shay JM (1992) Effect of water depth on population parameters of a Typha glauca stand. Canadian Journal of Botany 70:349-351

Webb J, Zhang X-H (2013) Organ-disparate allocation of plasticity in phosphorus response as an underlying mechanism for the sawgrass-to-cattail habitat shift in Florida Everglades wetlands. International Journal of Plant Sciences 174:779-790

Weiner SEB (1993) Long-term competitive displacement of Typha latifolia by Typha angustifolia in a eutrophic lake. Oecologia 94: 451-456

Weller MW (1975) Studies of cattail in relation to management for marsh wildlife. Iowa State Journal of Research 49:383-412

Weller MW (1988) Issues and approaches in assessing cumulative impacts on waterbird habitat in wetlands. Environmental Management 12:695-701

Welling CH, Pederson RL, van der Valk AG (1988) Temporal patterns in recruitment from the seed bank during drawdowns in a prairie wetland. Journal of Applied Ecology 25:999-1007

Werner KJ, Zedler JB (2002) How sedge meadow soils, microtopography, and vegetation respond to sedimentation. Wetlands 22:451-466
White JR, Reddy KR (2000) Influence of phosphorus loading on organic nitrogen mineralization of Everglades soils. Soil Science Society of America Journal 64:1525-1534

Whiting GJ, Chanton JP (1993) Primary production control of methane emission from wetlands. Nature 364:794

Wibbe JH (1880) WIS catalog number v0322384WIS

Wilcox DA (1986) The effects of deicing salts on vegetation in Pinhook bog, Indiana. Canadian Journal of Botany 64:865-874

Wilcox DA (2004) Implications of hydrologic variability on the succession of plants in Great Lakes wetlands. Aquatic Ecosystem Health \& Management 7:223-231

Wilcox DA, Meeker JE (1995) Wetlands in regulated Great Lakes. In: LaRoe ET, Farris GS, Puckett CE, Doran PD, Mac MJ (eds) Our living resources: a report to the nation on the distribution, abundance, and health of U.S. plants, animals, and ecosystems. U.S. Department of the Interior, National Biological Service, Washington, D.C., pp 247-249

Wilcox DA, Xie Y (2007) Predicting wetland plant community responses to proposed water-level-regulation plans for Lake Ontario: GISbased modeling. Journal of Great Lakes Research 33:751-773

Wilcox DA, Xie Y (2008) Predicted effects of proposed new regulation plans on sedge/grass meadows of Lake Ontario. Journal of Great Lakes Research 34:745-754

Wilcox DA, Apfelbaum SI, Hiebert RD (1984) Cattail invasion of sedge meadows following hydrologic disturbance in the Cowles bog wetland complex, Indiana dunes National Lakeshore. Wetlands 4:115128

Wilcox DA, Kowalski KP, Hoare HL, Carlson ML, Morgan HN (2008) Cattail invasion of sedge/grass meadows in Lake Ontario: photointerpretation analysis of sixteen wetlands over five decades. Journal of Great Lakes Research 34:301-323

Wilcox DA, Buckler K, Czayka A (2018) Controlling cattail invasion in sedge / grass meadows. Wetlands 38:337-347

Wiltermuth MT (2014) Influences of climate variability and landscape modifications on water dynamics, community structure, and amphipod populations in large prairie wetlands: Implications for waterbird conservation. Dissertation, North Dakota State University

Wiltermuth MT, Anteau MJ (2016) Is consolidation drainage an indirect mechanism for increased abundance of cattail in northern prairie wetlands? Wetlands Ecology and Management 24:533-544

Windham-Myers L, Bergamaschi B, Anderson F, Knox S, Miller R, Fujii $\mathrm{R}$ (2018) Potential for negative emissions of greenhouse gases $\left(\mathrm{CO}_{2}\right.$, $\mathrm{CH}_{4}$ and $\mathrm{N}_{2} \mathrm{O}$ ) through coastal peatland re-establishment: novel insights from high frequency flux data at meter and kilometer scales. Environmental Research Letters 13:045005

Woo I, Zedler JB (2002) Can nutrients alone shift a sedge meadow towards dominance by the invasive Typha $\times$ glauca. Wetlands 22: 509-521

Woodcock EF (1925) Observations of the poisonous plants of Michigan. American Journal of Botany 12:116-131

Wu Y, Rutchey K, Newman S, Miao S, Wang N, Sklar FH, Orem WH (2012) Impacts of fire and phosphorus on sawgrass and cattails in an altered landscape of the Florida Everglades. Ecological Processes $1(8)$

Wunderlin RP, Hansen BF, Franck AR, Essig FB (2018) Atlas of Florida plants. Available via USF. http://florida.plantatlas.usf.edu/. Accessed 1 Sept 2018

Yavitt JB, Knapp AK (1995) Methane emission to the atmosphere through emergent cattail (Typha latifolia L.) plants. Tellus Series B: Chemical and Physical Meteorology 47:521-534

Yavitt JB, Knapp AK (1998) Aspects of methane flow from sediment through emergent cattail (Typha latifolia) plants. New Phytologist 139:495-503

Yeo RR (1964) Life history of common cattail. Weeds 12:284-288 
Young EO, Ross DS (2001) Phosphate release from seasonally flooded soils: a laboratory microcosm study. Journal of Environmental Quality 30:91-101

Yozzo DJ, Osgood DT (2013) Invertebrate communities of low-salinity wetlands: overview and comparison between Phragmites and Typha marshes within the Hudson River estuary. Estuaries and Coasts 36: 575-584

Yu M, Han Y, Li J, Wang L (2017) $\mathrm{CO}_{2}$-activated porous carbon derived from cattail biomass for removal of malachite green dye and application as supercapacitors. Chemical Engineering Journal 317:493502

Zapfe L, Freeland JR (2015) Heterosis in invasive F1 cattail hybrids $($ Typha $\times$ glauca). Aquatic Botany 125:44-47

Zedler JB (2000) Progress in wetland restoration ecology. Trends in Ecology \& Evolution 15:402-407

Zedler JB, Paling E, McComb A (1990) Differential responses to salinity help explain the replacement of native Juncus kraussii by Typha orientalis in Western Australian salt marshes. Australian Journal of Ecology 15:57-72

Zhang X-H, Tapia M, Webb JB, Huang Y-H, Miao S (2008) Molecular signatures of two cattail species, Typha domingensis and Typha latifolia (Typhaceae), in South Florida. Molecular Phylogenetics and Evolution 49:368-376
Zhang Y, Ding W, Cai Z, Valerie P, Han F (2010) Response of methane emission to invasion of Spartina alterniflora and exogenous $\mathrm{N}$ deposition in the coastal salt marsh. Atmospheric Environment 44: 4588-4594

Zheng T, Sutton NB, de Jager P, Grosshans R, Munira S, Farenhorst A (2017) Glyphosate (ab)sorption by shoots and rhizomes of native versus hybrid cattail (Typha). Bulletin of Environmental Contamination and Toxicology 99:595-600

Zhou B, Tu T, Kong F, Wen J, Xu X (2018) Revised phylogeny and historical biogeography of the cosmopolitan aquatic plant genus Typha (Typhaceae). Scientific Reports 8:8813

Zweig CL, Newman S (2015) Using landscape context to map invasive species with medium-resolution satellite imagery. Restoration Ecology 23:524-530

Publisher's Note Springer Nature remains neutral with regard to jurisdictional claims in published maps and institutional affiliations.

\section{Affiliations}

\section{Sheel Bansal ${ }^{1}$ (D) Shane C. Lishawa ${ }^{2} \cdot$ Sue Newman ${ }^{3} \cdot$ Brian A. Tangen $^{1} \cdot$ Douglas Wilcox $^{4} \cdot$ Dennis Albert $^{5}$. Michael J. Anteau ${ }^{1} \cdot$ Michael J. Chimney ${ }^{3} \cdot$ Ryann L. Cressey ${ }^{6,7} \cdot$ Edward DeKeyser $^{8} \cdot$ Kenneth J. Elgersma $^{9}$. Sarah A. Finkelstein ${ }^{10}$. Joanna Freeland ${ }^{11} \cdot$ Richard Grosshans ${ }^{12} \cdot$ Page E. Klug ${ }^{13}$. Daniel J. Larkin ${ }^{14}$. Beth A. Lawrence ${ }^{15} \cdot$ George Linz $^{13} \cdot$ Joy Marburger ${ }^{16} \cdot$ Gregory Noe $^{17} \cdot$ Clint Otto $^{1} \cdot$ Nicholas Reo $^{18}$. Jennifer Richards ${ }^{19}$. Curtis Richardson ${ }^{20}$ • LeRoy Rodgers ${ }^{3}$. Amy J. Schrank ${ }^{21}$ • Dan Svedarsky ${ }^{22}$. Steven Travis ${ }^{23}$. Nancy Tuchman ${ }^{2} \cdot$ Lisamarie Windham-Myers ${ }^{24}$}

1 U.S. Geological Survey, Northern Prairie Wildlife Research Center, 8711 37th St. Southeast, Jamestown, ND 58401, USA

2 Loyola University Chicago, Institute of Environmental Sustainability, 32 W. Sheridan Rd, Chicago, IL 60660, USA

3 South Florida Water Management District, 3301 Gun Club Rd, West Palm Beach, FL 33406, USA

4 Department of Environmental Science and Ecology, SUNY College at Brockport, 350 New Campus Drive, Brockport, NY 14420, USA

5 Horticulture Department, Oregon State University, 4017 ALS Building, Corvallis, OR 97331, USA

6 Ducks Unlimited, Great Plains Regional Office, 2525 River Road, Bismarck, ND 58503, USA

7 Wisconsin Department of Natural Resources, 2984 Ave. Green Bay, Shawano, WI 54313, USA

8 School of Natural Resource Sciences, Department 7150, North Dakota State University, PO Box 6050, Fargo, ND 58108, USA
9 Department of Biology, University of Northern Iowa, 1227 W. 27th St, Cedar Falls, IA 50614, USA

10 Department of Earth Sciences, University of Toronto, Toronto, Ontario M5S 3B1, Canada

11 Department of Biology, Trent University, 1600 West Bank Drive, Peterborough, Ontario K9L 0G2, Canada

12 International Institute for Sustainable Development, 325-111 Lombard Ave, Winnipeg, Manitoba R3B 0T4, Canada

13 U.S. Department of Agriculture, Animal and Plant Health Inspection Service, Wildlife Services, National Wildlife Research Center, North Dakota Field Station, Department of Biological Sciences, North Dakota State University, 1340 Bolley Drive, Fargo, ND 58102, USA

14 Department of Fisheries, Wildlife and Conservation Biology \& Minnesota Aquatic Invasive Species Research Center, University of Minnesota, 135 Skok Hall, 2003 Upper Buford Circle, St. Paul, MN 55108, USA 
15 Department of Natural Resources and the Environment, Center for Environmental Science and Engineering, University of Connecticut, Storrs, CT 06269, USA

16 National Park Service (Retired), Great Lakes Research and Education Center, Indiana Dunes National Lakeshore, Porter, IN 46304, USA

17 U.S. Geological Survey, Hydrological-Ecological Interactions Branch, 430 National Center, Reston, VA 20192, USA

18 Environmental Studies and Native American Studies, Dartmouth College, 37 North Main St, Hanover, NH 03755, USA

19 Department of Biological Sciences, Florida International University, 11200 SW 8th St, Miami, FL 33199, USA
20

Duke University Wetland Center, Nicholas School of the Environment, Durham, NC 27705, USA

21 Department of Fisheries, Wildlife and Conservation Biology, University of Minnesota, 135 Skok Hall, 2003 Upper Buford Circle, St. Paul, MN 55108, USA

22 Northwest Research and Outreach Center (Retired), University of Minnesota, 2900 University Avenue, Crookston, MN 56716, USA

23 Department of Biology, University of New England, 11 Hills Beach Road, Biddeford, ME 04005, USA

24 U.S. Geological Survey, Water Mission Area, 345 Middlefield Road, Menlo Park, CA 94025, USA 